\title{
TRANSPORTATION AND PACKAGING RESOURCE GUIDE
}

J. W. Arendt

R. M. Gove

M. J. Welch

December 1994

Prepared for the

Office for Environment, Safety and Health

HA 0109

Prepared by

OAK RIDGE NATIONAL LABORATORY

Oak Ridge, Tennessee 37831-6285

managed by

MARTIN MARIETTA ENERGY SYSTEMS, INC.

for the

U.S. Department of Energy

under contract DE-AC05-84OR21400 
1. INTRODUCTION

2. ABBREVIATIONS AND ACRONYMS

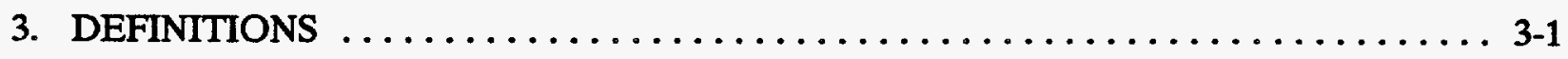

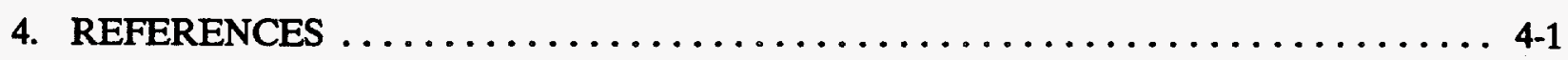

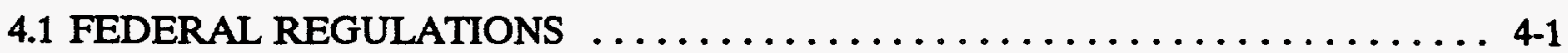

4.1.1 U.S. Nuclear Regulatory Commission $\ldots \ldots \ldots \ldots \ldots \ldots \ldots \ldots \ldots \ldots, 4,1$

4.1.2 U.S. Department of Energy .........................

4.1.3 U.S. Department of Commerce ....................... 4-1

4.1.4 U.S. Department of the Treasury, U.S. Customs Service $\ldots \ldots \ldots \ldots \ldots \ldots$ 4-1

4.1.5 U.S. Department of Labor $\ldots \ldots \ldots \ldots \ldots \ldots \ldots \ldots \ldots \ldots \ldots \ldots \ldots \ldots \ldots \ldots \ldots \ldots, 2$

4.1.6 U.S. Environmental Protection Agency $\ldots \ldots \ldots \ldots \ldots \ldots \ldots \ldots \ldots, 4.2$

4.1.7 General Services Administration $\ldots \ldots \ldots \ldots \ldots \ldots \ldots \ldots \ldots \ldots, 4,2$

4.1.8 U.S. Department of Health and Human Services $\ldots \ldots \ldots \ldots \ldots \ldots \ldots, 43$

4.1.9 U.S. Department of Transportation ..................... 4 .3

4.1.10 U.S. Postal Service $\ldots \ldots \ldots \ldots \ldots \ldots \ldots \ldots \ldots \ldots \ldots \ldots \ldots, 4,4$

4.2 FEDERAL LAWS $\ldots \ldots \ldots \ldots \ldots \ldots \ldots \ldots \ldots \ldots \ldots \ldots \ldots \ldots \ldots \ldots, 4,4$

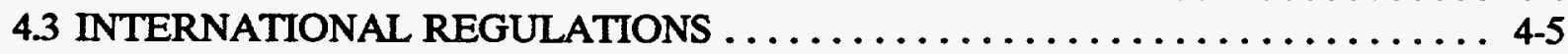

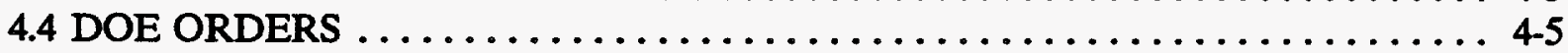

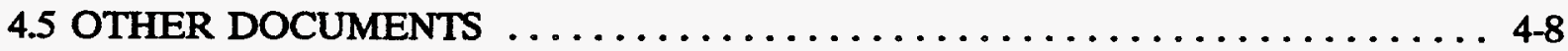

4.6 METRIC INFORMATION $\ldots \ldots \ldots \ldots \ldots \ldots \ldots \ldots \ldots \ldots \ldots \ldots \ldots \ldots, 4,10$

Appendix A: DOE DIRECTIVES CHECK LIST AS OF $5 / 27 / 94 \ldots \ldots \ldots \ldots \ldots \ldots$ A-1

Appendix B: REGULATION, PART AND SECTION NUMBERS OF DEFINITIONS .. B-1 


\section{DISCLAIMER}

This report was prepared as an account of work sponsored by an agency of the United States Government. Neither the United States Government nor any agency thereof, nor any of their employees, make any warranty, express or implied, or assumes any legal liability or responsibility for the accuracy, completeness, or usefulness of any information, apparatus, product, or process disclosed, or represents that its use would not infringe privately owned rights. Reference herein to any specific commercial product, process, or service by trade name, trademark, manufacturer, or otherwise does not necessarily constitute or imply its endorsement, recommendation, or favoring by the United States Government or any agency thereof. The views and opinions of authors expressed herein do not necessarily state or reflect those of the United States Government or any agency thereof. 


\section{DISCLAIMER}

Portions of this document may be illegible in electronic image products. Images are produced from the best available original document. 


\section{LIST OF TABLES}

Page

Table 1 Seven base SI units $\ldots \ldots \ldots \ldots \ldots \ldots \ldots \ldots \ldots \ldots \ldots \ldots \ldots \ldots \ldots \ldots$

Table 2 Two supplementary units $\ldots \ldots \ldots \ldots \ldots \ldots \ldots \ldots \ldots \ldots \ldots \ldots \ldots \ldots \ldots \ldots$

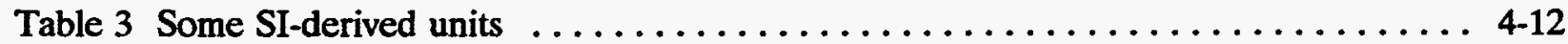

Table 4 Some SI-derived units with special names $\ldots \ldots \ldots \ldots \ldots \ldots \ldots \ldots \ldots$

Table 5 Conversions for some other units $\ldots \ldots \ldots \ldots \ldots \ldots \ldots \ldots \ldots \ldots \ldots \ldots$. . . . . . . . .

Table 6 SI prefixes $\ldots \ldots \ldots \ldots \ldots \ldots \ldots \ldots \ldots \ldots \ldots \ldots \ldots \ldots \ldots \ldots \ldots \ldots \ldots$ 


\section{INTRODUCTION}

The purpose of this resource guide is to provide a convenient reference document of information that may be useful to the U.S. Department of Energy (DOE) and DOE contractor personnel involved in packaging and transportation activities. It may be useful also to those in other disciplines, including those indirectly associated with packaging and transportation.

An attempt has been made to present the terminology of DOE community usage as it currently exists. DOE's mission is changing with emphasis on environmental cleanup. The terminology or nomenclature that has resulted from this expanded mission is included for the packaging and transportation user for reference purposes. Older terms still in use during the transition have been maintained. The Packaging and Transportation Resource Guide consists of four sections: Sect. 1, "Introduction"; Sect. 2, "Abbreviations and Acronyms"; Sect. 3, "Definitions"; and Sect. 4, "References" for packaging and transportation of hazardous materials and related activities, and Appendices A and B. Information has been collected from DOE Orders and DOE documents; U.S Department of Transportation (DOT), U.S. Environmental Protection Agency (EPA), and U.S. Nuclear Regulatory Commission (NRC) regulations; and International Atomic Energy Agency (IAEA) standards and other international documents. The definitions included in this guide may not always be a regulatory definition but are the more common DOE usage. In addition, the definitions vary among regulatory agencies. It is, therefore, suggested that if a definition is to be used in a regulatory or a legal compliance issue, the definition should be verified with the appropriate regulation. To assist in locating definitions in the regulations, a listing of all definition sections in the regulations are included in Appendix B. In many instances, the appropriate regulatory reference is indicated in the right-hand margin.

DOE Orders for packaging and transportation are included in the reference section. For completeness, all DOE Orders are listed in Appendix A. This resource guide will be reviewed annually for updating. Suggestions for improvement (additions or deletions) are encouraged; these should be sent to Miriam. J. Welch, Martin Marietta Energy Systems, Inc., Oak Ridge National Laboratory, P.O. Box 2008, 105MIT, Oak Ridge, TN, 37831-6495; telephone 615/5745068; telefax 615/574-3431. 


\section{ABBREVIATIONS AND ACRONYMS}

AAR

AASHTO

ACGIH

ADP

AEC

AECB

AECL

AGA

AICHE

AIHA

AISC

AISI

ALARA

ANI

ANPRM

ANS

ANSI

API

ASCE

ASME

ASNT

ASQC

ASSE

ASTM

ATA

ATMS

ATSDR

AWS

BAT
Association of American Railroads

American Association of State Highway and

Transportation Officials

American Conference of Governmental Industrial Hygienists

Automatic Data Processing

U.S. Atomic Energy Commission

Atomic Energy Control Board (Canada)

Atomic Energy of Canada, Limited

American Gas Association

American Institute of Chemical Engineers

American Industrial Hygiene Association

American Institute of Steel Construction, Inc.

American Iron and Steel Institute

As low as reasonably achievable

American Nuclear Insurers

Advance Notice of Proposed Rulemaking

American Nuclear Society

American National Standards Institute, Inc.

American Petroleum Institute

American Society of Civil Engineers

American Society of Mechanical Engineers

American Society for Nondestructive Testing

American Society of Quality Control

American Society of Safety Engineers

American Society for Testing and Materials

American Trucking Association; also Air Transport Associations, Inc.

Automated Transportation Management System

Agency for Toxic Substance Disease Registry

American Welding Society

Breath analyzer technician 
BIA

BMCS

BOE

BOM

BPA

$\mathrm{Bq}$

CAA

$\mathrm{CAB}$

CANUTEC

CAS

CDL

CDLIS

CEGB

CEN

CENELEC

CERCLA

CERCLIS

CFR

CGA

CHEMNET

CHEMTREC

CHLOREP

CHRIS

$\mathrm{Ci}$

CMA

CMV

CMVD

CoC

$\mathrm{COCO}$

CofCA

COFC/TOFC

COTP
Bureau of Indian Affairs

Bureau of Motor Carrier Safety

Bureau of Explosives

Bureau of Mines

Bonneville Power Administration

Becquerel

Clean Air Act

Civil Aeronautics Board

Canadian Transport Emergency Centre

Chemical Abstracts Service

Commercial drivers license

Commercial Drivers License Information System

Central Electricity Generating Board

European Committee for Standardization

European Committee for Electrotechnical Standardization

Comprehensive Environmental Response, Compensation, and Liability Act

CERCLA Information System

Code of Federal Regulations

Compressed Gas Association

Chemical Network, Chemical Manufacturers Association

Chemical Transportation Emergency Center

Chlorine Emergency Plan (Chlorine Institute)

Chemical Hazards Response Information System

Curie

Chemical Manufacturers Association

Commercial motor vehicle

Commercial Motor Vehicle Driver

Certificate of Compliance

Contractor owned, contractor operated

Certificate of Competent Authority

Container on flatcar/trailer on flatcar (piggyback)

Captain of the Port 
cpm

CR

CRCPD

CSO

CTMA

CVSA

CWA

DBA

D\&D

DERP

DHHS

DIS

DMIS

DNFSB

DOC

DoD

DOE

DOE-HQ

DOESI

DOI

DOJ

DOL

DOT

DOT-TSI

DP

DPM

$\mathrm{DPM} / \mathrm{m}^{3}$

DU

DVIR

DWPF

EAP

EC
Counts per minute

DOE Office of Chief Financial Officer

Conference of Radiation Control Program Directors, Inc.

Cognizant Secretarial Officer

Contractor Traffic Managers Association (DOE)

Commercial Vehicle Safety Alliance

Clean Water Act

Design-basis accident

Decontamination and decommissioning

U.S. Defense Environmental Restoration Program

U.S. Department of Health and Human Services

Draft International Standard

Disaster Management Information System

U.S. Defense Nuclear Facility Safety Board

U.S. Department of Commerce

U.S. Department of Defense

U.S. Department of Energy

U.S. DOE-Headquarters

DOE Standards Index

U.S. Department of the Interior

U.S. Department of Justice

U.S. Department of Labor

U.S. Department of Transportation

DOT Transportation Safety Institute

DOE Office of Defense Programs

Disintegrations per minute

Disintegrations per minute per cubic meter

Depleted uranium

Driver vehicle inspection report

Defense Waste Processing Facility

Employee assistance program

European Community 
DOE Office of Energy Efficiencies and Renewable Energy

EH

DOE Office of Environment, Safety and Health

EHTR

Emergency Highway Traffic Regulations

EHTRC

Emergency Highway Traffic Regulation Center

EIA

DOE Energy Information Administration

EIS

Environmental impact statement

EM

DOE Office of Environmental Management

EMI

Emergency Management Institute

EN

European standard

ENV

European prestandard

EOC

Emergency Operations Center

EPA

ER

U.S. Environmental Protection Agency

ERC

DOE Office of Energy Research

ERDA

Emergency response center

ERG

U.S. Energy Research and Development Administration

EM

ET

Emergency response guidebook

ETSI

DOE Office of Environmental Management

FAA

DOE Office of Science Education and Technical Information

FE

European Telecommunications Standards Institute

FEMA

Federal Aviation Administration

FEIS

DOE Office of Fossil Energy

FFA

Federal Emergency Management Agency

FFCA

Final environmental impact statement

FFER

Federal Facility Agreement

FHWA

Federal Facility Compliance Act

FM

Federal Facility Environmental Restoration

FMCSR

Federal Highway Administration

FO

DOE Office of Field Management

FOIA

Federal Motor Carrier Safety Regulations

Field Office

$F R$

Freedom of Information Act

Federal Register ${ }^{\circ}$ 
FRA

FRERP

FSAR

FUDS

FUSRAP

FY

GAO

GAWR

GC

GCWR

GET

GOCO

GOGO

GSA

GVW

GVWR

HAZCHEM

HAZCOM

HAZMAT

HAZWOPER

HAZWRAP

$\mathrm{HCO}$

HCS

HD

HDBK

HEU

HIT

HLW

HM

HMAC

HMCP

HMI
Federal Railroad Administration

Federal Radiological Emergency Response Plan

Final safety analysis report

Formerly used defense sites

Formerly Utilized Sites Remedial Action Program

Fiscal year

U.S. General Accounting Office

Gross axle-weight rating

DOE Office of General Counsel

Gross combination-weight rating

General employee training

Government owned, contractor operated

Government owned, government operated

General Services Administration

Gross vehicle weight

Gross vehicle weight rating

Hazardous chemicals

Hazardous communication

Hazardous materials

Hazardous waste operations and emergency response

Hazardous Waste Remedial Actions Program

Headquarters (Packaging) Certification Official

Hazard communications standard

Harmonization document

Handbook

Highly enriched uranium

Hazard information transmission

High-level waste

Hazard mitigation

Hazardous Materials Advisory Council

HAZMAT Contingency Planning Course

Hazardous material incident 
HMIR

HMIS

HMIX

HMR

HMRB

HMTA

HMTUSA

HOD

HP

HPS

HR

HRCQ

HSDB

HSRI

HUD

IACP

IAEA

IAFC

IAFF

IAG

IATA

IAW

ICAO

ICAP

ICC

ICRP

IDLH

IEC

IEEE

IG

IM
Hazardous materials incident reports

Hazardous Materials Information System; also Hazardous Materials

Identification System

Hazardous Materials Information Exchange

Hazardous materials regulation

Hazardous Materials Regulations Board

Hazardous Materials Transportation Act

Hazardous Materials Transportation Uniform Safety Act

Head of the delegation

Health physics

Health Physics Society

DOE Office of Human Resources and Administration

Highway route-controlled quantity

Hazardous Substances Data Bank

Highway Safety Research Institute (University of Michigan)

U.S. Department of Housing and Urban Development

International Association of Chiefs of Police

International Atomic Energy Agency

International Association of Fire Chiefs

International Association of Fire Fighters

Interagency Agreement

International Air Transport Association

In accordance with

International Civil Aviation Organization

Interagency Committee for Aviation Policy

Interstate Commerce Commission

International Commission on Radiological Protection

Immediately dangerous to life and health

International Electrotechnical Commission

Institute of Electrical and Electronics Engineers

DOE Office of the Inspector General

Intermodal 
IMDG

IMO

INMM

INMTS

INPO

IS

ISA

ISEA

ISO

JTC

LDR

LEL

LFL

LLEA

LLRWPA

LLS

LLW

LM

LNG

LOI

LPG

LSA

LTD QTY

LTL

LWT

MAWP

MIL

MIS

M\&O

MONAL

MORT

MOU
International Maritime Dangerous Goods

International Maritime Organization

Institute of Nuclear Materials Management

International Nuclear Material Tracking System

Institute of Nuclear Power Operations

DOE Office of Intelligence and National Security

Instrument Society of America

Industrial Safety Equipment Association

International Organization for Standardization

Joint Technical Committee

Land-disposal restriction

Lower explosive limit

Lower flammable limit

Local law enforcement agency

Low-Level Radiative Waste Policy Act

Low-level solid

Low-level waste

DOE Office of Laboratory Management

Liquified natural gas

Lines of inquiry

Liquified-petroleum gas

Low specific activity

Limited-quantity shipments

Less-then-truckload

Legal weight truck

Maximum allowable working pressure

Military standard

Management Information System

Management and operating

Mobile Nondestructive Assay Laboratory

Management oversight and risk tree

Memorandum of understanding 
MPC

MRO

MRS

MSDS

MSHA

MSS

MTU

NAHMI

NAS

NASA

NASS

NB

NBS

NCAI

NCP

NCRIC

NCRP

NE

NEPA

NESHAP

NFPA

NGS

NGSB

NHTSA

NIOSH

NISO

NIST

NMC\&A

NMFC

NMMSS

NMTDB
Maximum permissible concentration, also multipurpose canister

Medical review officer

Monitored retrievable storage

Material safety data sheet

DOL Mine Safety and Health Administration

Manufacturers Standardization Society of the Valve and Fitting Industry

Metric tons uranium

National Alliance of Hazardous Materials Instructors

National Academy of Sciences

National Aeronautics and Space Administration

National Accident Sampling System

National Board of Boiler and Pressure Vessel Inspectors

National Bureau of Standards (now National Institute of Standards and

Technology)

National Congress of American Indians

National Contingency Plan

National Chemical Response and Information Center

National Council on Radiation Protection and Measurements

DOE Office of Nuclear Energy

National Environmental Policy Act

National Emission Standards for Hazardous Air Pollutants

National Fire Protection Association

Nongovernment standard

Nongovernment Standards Body

National Highway Transportation Safety Administration.

National Institute for Occupational Safety and Health

National Information Standards Organization

National Institute of Standards and Technology

Nuclear Materials Control and Accountability system

National Motor Freight Classification

Nuclear Materials Management and Safeguards System

National Motof Truck Data Base 
NOAA

NOIBN

NOS

NPL

NPRM

NPT

NRC

NRT

NSB

NTAG

NTCN

NTIA

NTIS

NTMS

NTP

NTSB

NTTC

NUREG

NWPA

OHMT

OJT

O\&M

OMB

ORM

ORPS

OSHA

OSS

OSTI

OSTP
National Oceanic and Atmospheric Administration

Not otherwise indicated by name

Not otherwise specified

National Priorities List

Notice of Proposed Rulemaking

National taper pipe (thread)

U.S. Nuclear Regulatory Commission, also National Response Center (U.S.

Coast Guard)

National Response Team

Nuclear Standards Board

Nuclear Technical Advisory Board

National Telecommunications Network

National Telecommunication and Information Administration

National Technical Information Service

National Telecommunications Management System

National Toxicology Program

National Transportation Safety Board

National Tank Truck Carriers, Inc.

Nuclear Regulatory Guide (NRC reports category)

Nuclear Waste Policy Act

Office of Hazardous Materials Transportation

On-the-job training

Operations and maintenance

Office of Management and Budget (Executive Office of the U.S.

Government)

Other regulated materials

Occurrence Reporting and Processing System (DOE)

Occupational Safety and Health Administration (DOL)

DOE Office of Safeguards and Security

DOE Office of Scientific and Technical Information

Office of Science and Technology Policy (Executive Office of the U.S.

Government) 
OTA

OTSM

OWT

PAA

PAT

PATS

PATRAM

PCB

PEIS

PEL

PG

PHS

PIH

PIN

PIRS

PMP

PPE

PPM

PRP

PSI

PSN

P\&T

PTRA

QA

QC

RADCON

RAM(s)

RAMPAC

RAMRT

RAP

RAT
Office of Technology Assessment (U.S. Congress)

On-Site Transportation Safety Manual (DOE)

Overweight truck

Price-Anderson Act

Plutonium air transportable (packaging)

Packaging and transportation safety

Packaging and Transportation of Radioactive Materials (International conference)

Polychlorinated biphenyls

Programmatic environmental impact statement

Permissible exposure limit

Packing group number

U.S. Public Health Service

Poison-inhalation hazard

Product identification number

Pollution Incident Reporting System

Preventive Maintenance Program

Personal protective equipment

Parts per million

Potentially responsible party

Pounds per square inch

Proper shipping name

Packaging and transportation

Port Terminal Rail Authority

Quality assurance

Quality control

Radiological control/reliability, accessibility and maintainability

Radioactive material(s)

Radioactive materials packages (data base)

Radioactive Materials Routing Report

Radiological Assistance Program

Radiological assistance team 
RCRA

R\&D

REAC/TS

REO

RI/FS

ROD

RP

$\mathbf{R Q}$

RRT

RSPA

RW

SAE

SAP

SAR

SARA

SARP

SCALE

SCANS

SCBA

SCF

$\mathrm{SCO}$

SCRA

SER

SG

SHMED

SI

SIC

SIG

SMAC

SNF

SNM

SOP
Resource Conservation and Recovery Act

Research and development

Radiation Emergency Assistance Center/Training Site

Regional environmental officers

Remedial investigation/feasibility study

Record of Decision

Radiation protection

Reportable quantity

Regional response team

Research and Special Programs Administration (DOT)

DOE Office of Civilian Radioactive Waste Management

Society of Automotive Engineers

Substance abuse professional

Safety analysis report

Superfund Amendments and Reauthorization Act

Safety Analysis Report for Packaging

Standardized computer analyses for licensing evaluation

Shipping Cask Analysis System

Self-contained breathing apparatus

Standard cubic feet

Surface-contaminated object

Specialized Carriers and Rigging Association

Safety Evaluation Report

Safety Guide

State Hazardous Materials Enforcement Development program

International System of Units (Systeme International d Unites)

Standard Industrial Classification

Special interest group

Shipment/mobility accountability collection (data base)

Spent nuclear fuel

Special nuclear material

Standard operating procedure 


\begin{tabular}{|c|c|}
\hline SPCC & Spill Prevention, Control and Countermeasure Plan \\
\hline SPCL & Standard Point Location Code (geocodification of the United States) \\
\hline SPMS & Safety Performance Measurement System \\
\hline SPP & Standard practice procedure \\
\hline SSAB & Site-Specific Advisory Board \\
\hline SSNM & Strategic special nuclear material \\
\hline SSR & Safe-secure railcar \\
\hline SSRMT & State surveillance of radioactive materials transportation \\
\hline SST & Safe-secure trailer \\
\hline STAA & Surface Transportation Assistance Act \\
\hline STC & Single-trip container \\
\hline STCC & Standard Transportation Commodity Code (ICC) \\
\hline STEL & Short-term exposure limit \\
\hline STS & Special train service \\
\hline SVTC & Silicon Valley Toxics Coalition \\
\hline TA & Technical advisor \\
\hline TAG & Technical advisory group \\
\hline TBD & To be determined \\
\hline TC & Technical committee \\
\hline TCE & Trichloroethylene \\
\hline TDG & Transportation of Dangerous Goods Regulations \\
\hline TEPP & Transportation Emergency Preparedness Program \\
\hline TI & Transport Index \\
\hline TIN & Transportation Information Network (EM) \\
\hline TIS & Technical Information System (EH) \\
\hline TKC & The Keystone Center \\
\hline TL & Threshold limit \\
\hline TLD & Thermoluminescent dosimeter \\
\hline TLV & Threshold-limit value \\
\hline $\mathrm{TLV}-\mathrm{C}$ & Threshold-limit value-ceiling \\
\hline TLV-TWA & Threshold-limit value-time-weighted average \\
\hline TMD & Transportation Management Division (DOE-EM-261) \\
\hline
\end{tabular}


TOFC

TPSD

TQL

TQM

TRADE

TRANSCOM

TRC

TRQ

TRU

TRUPACT-II

TSA

TSC

TSCA

TSD

TSUSA

TTMA

TWA

UCNI

UEC

UEL

UFC

UL

UMTRAP

UMTRI

UN/NA

UNK

UOR

U.S.C.

USCG

USDA
Trailer on flatcar

Transportation and Packaging Safety Division (DOE-EH-332)

Threshold-quantity level

Total quality management

Training Resources and Data Exchange (Oak Ridge Associated Universities)

U.S. Department of Energy Transportation Tracking and

Communications System

DOD Technical Review Committee

Threshold reporting quantity

Transuranic material

Transuranic Package Transporter-II

Technical Safety Appraisal

Transportation System Center

Toxic Substances Control Act

Treatment, storage, and/or disposal (facilities)

Tariff Schedule for United States Annotated

Truck Trailers Manufacturers Association

Time-weighted average

Unclassified controlled nuclear information

Uranium Enrichment Corporation

Upper explosive limit

Uniform freight classification

Underwriters' Laboratories

Uranium Mill Tailings Remedial Action Program

University of Michigan Transportation Research Institute

United Nations/North American hazardous materials code

Unknown

Unusual occurrence report

U.S. Code

U.S. Coast Guard

U.S. Department of Agriculture 
USNC

VIN

WBS

WD

WG

WIPP
U.S. National Committee for IEC

Vehicle identification number

Work breakdown structure

Working draft

Working group

Waste Isolation Pilot Plant 


\section{DEFINITIONS}

$\mathbf{A}_{1}$

The maximum activity of special-form radioactive material permitted in a Type A package.

$\mathbf{A}_{2}$

Accident

Accident

conditions

Activity release

rate

\section{Air Waybill}

ALARA (as low as reasonably achievable)
The maximum activity of radioactive material, other than special form or low specific activity radioactive material, permitted in a Type A package.

An occurrence involving a commercial motor vehicle operating on a public road which results in:

1. a fatality,

2. bodily injury to a person who, as a result of the injury, immediately receives medical treatment away from the scene of the accident, or

3. one or more motor vehicles incurring disabling damage as a result of the accident, requiring the vehicle to be transported away from the scene by a tow truck or other vehicle.

Hypothetical accident conditions are those used as described in the NRC regulations for evaluation of package design.

Loss of radioactive contents per unit time which passes through leaks or permeable walls of a containment system.

\section{See Shipping Paper and Shipper's Declaration for} Dangerous Goods.

As low as is reasonably achievable taking into account the state of technology and the economics of improvements in relation to: (1) benefits to the public health and safety, (2) benefits to the radiation workers who are occupationally exposed, (3) other societal and socioeconomic considerations, and (4) the utilization of atomic energy in the public interest.
49 CFR Part 173.403; see also 10 CFR Part 71.4 and IAEA Safety Series 6.

49 CFR Parts 173.403; see also 49 CFR Parts 173.433 and .435 and IAEA Safety Series 6.

49 CFR Part 390.5

10 CFR Part 71.73

10 CFR Part 35.2 
Alpha particle

Appraisal

(technical

ascessment)

Atmospheric

gases

Atom

\section{Atomic Energy Act}

Authorized inspector

Authorized Inspection Agency
A positively charged particle emitted by the nucleus of some radioactive materials undergoing radioactive decay. Alpha particles are the least penetrating of the three common forms of radiation (alpha, beta, gamma); they can be stopped by a sheet of paper or an inch of air. Alpha particles cannot penetrate skin, but materials that emit alpha particles (alpha emitters) are harmful if inhaled or ingested.

A documented review of a field element or facility's transportation and/or packaging management discipline performed in accordance with written guidance and criteria to verify, by examination and evaluation of objective evidence at the facility and/or operation, that applicable elements of the program have been developed, documented, and effectively implemented in accordance with specific requirements, needs, and regulations.

Air, nitrogen, oxygen, argon, krypton, neon, and xenon.

A unit of matter indivisible by chemical means. Atoms are the fundamental building blocks of chemical elements. Elements differ from each other because they are made up of different atoms.

The Act (1954) which placed production and control of nuclear materials within a civilian agency, originally the Atomic Energy Commission, now the U.S. Department of Energy.

An inspector who is currently commissioned by the National Board of Boiler and Pressure Vessel 49 CFR Part 171.8 Inspectors and employed as an inspector by an authorized inspection agency.

(1) A jurisdiction which has adopted and administers one or more sections of the American Society of Mechanical Engineers (ASME) Boiler and Pressure Vessel Code as a legal requirement and has a representative serving as a member of the ASME Conference Committee; or (2) an insurance company which has been licensed or registered by the appropriate authority of a state of the United States or a province of Canada. 
Background radiation

Bag

Bar

Barge

Basic description

Becquerel

Beta particle

Bill of Lading

Blasting agent

Blockage mechanism

Bottle
Radiation from cosmic sources; naturally occurring radioactive materials, including radon (except as a decay product of source or special nuclear material); and global fallout as it exists in the environment from the testing of nuclear explosive devices. "Background radiation" does not include radiation from source, byproduct, or special nuclear materials.

A flexible packaging made of paper, plastic film, textiles, woven material or other similar materials.

1 bar = $100 \mathrm{kPa}$ (14.5 psi); a unit of pressure equal to one million dynes per square centimeter.

A non-self-propelled vessel.

Identification of a hazardous material by its proper shipping name, hazard class, and identification number, in that sequence. Under the new hazardous materials rules, the basic description also includes the packing group number (I, II, or III).

The International System unit for activity of radioactive material. One becquerel is that quantity of radioactive material that undergoes one disintegration per second.

A negatively charged particle emitted from an atom during radioactive decay. Beta particles are easily stopped by a thin sheet of metal. Exposure to high levels of beta radiation can cause skin burns.

See Shipping paper.

Materials to be used for blasting (at construction sites or elsewhere), but any one of which is not likely to start an explosion by itself. See Explosives.

The mechanism by which radioactive material might be retained within a containment system due to blockage of potential leakage paths by solid or liquid material.

An inner packaging having a neck of relatively smaller cross section than the body and an opening capable of holding a closure for retention of the contents.
49 CFR Part 171.8

49 CFR Part 171.8

49 CFR Part 171.8 
Bottom shell

Box

Break-bulk

Bulk packaging

Burial grounds

Buried waste

By-products

\section{Calcining/ \\ Calcination}

\section{Canister}

Captain of the Port
That portion of the tank-car tank surface, excluding the head ends of the tank-car tank, that lies within $2 \mathrm{ft}$, measured circumferentially, of the bottom longitudinal center line of the tank-car tank.

A packaging with complete rectangular or polygonal faces, made of metal, wood, plywood, reconstituted wood, fiberboard, plastic, or other suitable material.

Packages of hazardous materials that are handled individually, palletized, or unitized for purposes of transportation as opposed to bulk and containerized freight.

A reference to such containers as tank cars, cargo tanks (tank trucks), or portable tanks.

Areas designated for near-surface disposal of containers of low-level radioactive waste and obsolete or worn-out radioactively contaminated equipment.

Low-level radioactive waste (or in some cases, pre1970 transuranic contaminated waste) that has been disposed of by near-surface burial. (See Transuranic waste)

Radioactive materials resulting from the production or processing of nuclear materials. Some by-products have beneficial commercial uses.

The process of making unconsolidated powder or granules by thermal evaporation and partial decomposition (release of gases) of high-level waste.

A container for radioactive waste forms, especially vitrified high-level liquid waste that has been solidified and immobilized. (See Vitrification.)

The Officer of the Coast Guard, under the command of a District Commander, so designated by the Commandant for the purpose of giving immediate direction to Coast Guard law enforcement activities within an assigned area. The term "Captain of the Port" includes an authorized representative of the Captain of the Port.
See also 49 CFR Part 171.8

49 CFR Part 171.8

49 CFR Part 171.8

49 CFR Part 171.8

See also 10 CFR Parts 20.3 and 40.4

49 CFR Part 171.8 
Carfloat

Cargo Aircraft

Cargo security

Cargo tank

\section{Cargo-tank motor vehicle}

Cargo vessel
A vessel that operates on a short run on an irregular basis and serves one or more points in a port area as an extension of a rail line or highway over water, and does not operate in ocean, coastal, or ferry service.

An aircraft that is used to transport cargo and is not engaged in carrying passengers. The terms "cargo aircraft only," "cargo-only aircraft," and "cargo aircraft" have the same meaning.

The physical protection against theft, pilferage, burglary, hijacking, sabotage, and vandalism of DOE cargo and vehicles in transit, including the physical protection of cargo and transportation safeguards.

A bulk packaging which:

1. is a tank intended primarily for the carriage of liquids or gases and includes appurtenances, reinforcements, fittings, and closures (for "tank", see 49 CFR $178.345-1$ (c), $178.337-1$, or $178.338-1$, as applicable),

2. is permanently attached to or forms a part of a motor vehicle, or is not permanently attached to a motor vehicle but which, by reason of its size, construction or attachment to a motor vehicle is loaded or unloaded without being removed from the motor vehicle, and

3. is not fabricated under a specification for cylinders, portable tanks, tank cars, or multiunit tank car tanks.

A motor vehicle with one or more cargo tanks permanently attached to or forming an integral part of the motor vehicle.

(1) Any vessel other than a passenger vessel and (2) any ferry being operated under authority of a change of character certificate issued by a Coast Guard Officer-in-Charge, Marine Inspection.
49 CFR Part 171.8 also see IAEA Safety Series 6

49 CFR Part 171.8 
Carrier

Chemical

Abstracts Service number

Cask

\section{Certificate of Compliance}

Certification

Character of vessel

Characterization

Chemical manufacturer

Chemical name
Any entity engaged in the transportation of property as a common, contract, or private carrier, or as a freight forwarder, as those terms are used in Federal statutes and regulations, as amended; by the U.S. Postal Service, or as officers, agents, and employees of such carriers.

A Chemical Abstracts Service, used standardized reference number for regulated materials.

A thick-walled container that provides shielding during the transportation of canisters of highly radioactive materials.

A certificate issued by the DOE or NRC, as appropriate, approving for use with specified limitations specific packaging for amounts of fissile or other radioactive materials exceeding the $\underline{A}_{1} / \underline{A}_{2}$ quantities defined in DOE and NRC regulations. A signed statement verifying compliance with applicable regulations.

The type of service in which the vessel is engaged at the time of carriage of a hazardous material.

Facility or site-sampling, -monitoring, and -analysis activities to determine the extent and nature the waste stream. Characterization provides the basis for acquiring the necessary technical information to develop, screen, analyze, and select appropriate cleanup techniques.

An employer with a work place where chemicals are produced for use or distribution.

Scientific designation of a chemical in accordance with the nomenclature system developed by the International Union of Pure and Applied Chemistry or the Chemical Abstracts Service rules of nomenclature, or a name which will clearly identify the chemical for the purpose of conducting a hazard evaluation. also see 49 CFR Part 171.8, 10 CFR Part 71.4 , and IAEA Safety Series 6

49 CFR Part 171.8

29 CFR Part

1910.1200

29 CFR Part

1910.1200 
Chemical plant

CHEMNET

Chemical

Transportation

Emergency

Center

Chlorine

Emergency Plan
Any chemical industry facility including manufacturing plant, distribution facilities, warehouses, and transportation vehicles located onsite.

Mutual aid network of chemical shippers and contractors composed of over 250 chemical emergency response teams and several emergency response contractors. Activated when a member shipper cannot respond promptly to an incident involving that company's product(s) and requiring the presence of a chemical expert. If a member company cannot go to the scene of the incident, the shipper will authorize a CHEMNET-contracted emergency response company to go. Responders act as advisors on safe techniques for securing the scene and dealing with spills and fires involving the chemical. If requested, the experts will provide "hands-on" assistance in capping and patching containers and in transferring the chemical from the damaged container.

Chemical Transportation Emergency Center, operated by the Chemical Manufacturers Association to provide information and/or assistance to member companies and emergency responders. CHEMTREC contacts the shipper or producer of the material for more detailed information on the chemical released to facilitate response and cleanup actions. CHEMTREC maintains technical information files on over 300,000 proprietary chemicals. During emergencies, CHEMTREC can provide information regarding the effects of most chemicals on persons or the environment and suggest methods for treatment, containment, and control of an incident. CHEMTREC also maintains a directory of experts and industry assistance teams that can assist in an emergency. CHEMTREC can be reached 24 hours a day (800-424-9300). REMEMBER: A call to CHEMTREC does not fulfill any statutory or regulatory reporting requirement of the federal government.

The Chlorine Emergency Plan, established by the Chlorine Institute to enable the nearest producer of chlorine to respond to an accident involving chlorine. CHEMTREC serves as the communication link for this program. 
Class

Classification

Clean Air Act

Cleanup

Clean Water Act of 1977

Closed transport vehicle
Closure

Cognizant

Secretarial

Officers
See Hazard Class and UN Class or Division Number.

A means of identifying groups of hazardous materials by their respective form and hazard characteristics.

The purpose of this Act is to "protect and enhance the quality of the nation's air resources." Its primary application is through permits to regulate new and existing facilities. Of increasing importance are the National Emissions Standards for Hazardous Air Pollutants. The Clean Air Act was passed in 1970 and was amended in 1977 and 1990.

Actions taken to correct a release or threat of release of a hazardous substance that could affect humans and/or the environment. The term cleanup is sometimes used interchangeably with the terms remedial action, removal action, response action, or corrective action or activity.

Amended the Federal Water Pollution Control Act passed in 1956. Its objective is to "restore and maintain the chemical, physical, and biological integrity of the nation's waters." The Act's major enforcement tool is the National Pollutant Discharge Elimination System permit. The Clean Water Act addresses surface waters only.

A transport vehicle equipped with a securely attached exterior enclosure that during normal transportation restricts the access of unauthorized persons to the cargo space containing the hazardous materials. The enclosure may be either temporary or permanent, and in the case of packaged materials, it may be of the "see-through" type, and must limit access from top, sides, and ends.

A device which closes an opening in a receptacle.

Senior outlay program officials, including the Assistant Secretaries for Conservation and Renewable Energy (CE), Defense Programs (DP), Fossil Energy (FE), and Nuclear Energy (NE), and the Directors of Energy Research (ER), Civilian Radioactive Waste Management (RW), and Environmental Restoration and Waste Management (EM). 
Combination package

Combustible liquid

Commerce

Commercial drivers's license

Commercial Driver's License Information System

Commercial motor vehicle
A type of nonbulk container consisting of one or more inner packagings secured in an outer packaging. It does not include a composite packaging.

Any liquid having a flash point at or above $100^{\circ} \mathrm{F}$ $\left(37.8^{\circ} \mathrm{C}\right)$, but below $200^{\circ} \mathrm{F}\left(93.3^{\circ} \mathrm{C}\right)$, except any mixture having components with flash points of $200^{\circ} \mathrm{F}\left(93.3^{\circ} \mathrm{C}\right)$, or higher, the total volume of which make up $99 \%$ or more of the total volume of the mixture. Liquids that can ignite only at temperatures higher than the temperature required for liquids are classed as "flammable." Combustible liquids (such as fuel oil), therefore, are considered dangerous, but not as dangerous as flammable liquids.

(a) any trade, traffic or transportation within the jurisdiction of the United States between a place in a state and a place outside of such state, including a place outside of the United States, and (b) trade, traffic, and transportation in the United States which affects any trade, traffic, and transportation described in paragraph (a) of this definition.

A license issued by an individual's state of residence which authorizes that person to operate a class or classes of commercial motor vehicles.

The CDLIS established by the Federal Highway Administration.

Any self-propelled or towed vehicle used on public highways in interstate commerce to transport passengers or property if:

1. the vehicle has a gross combination weight rating or gross combination weight rating of 10,001 or more pounds; or

2. is designed to transport more that $\mathbf{1 5}$ passengers, including the driver; or
See also 49 CFR Part 171.8

29 CFR Part 1910.1200; see also 49 CFR Part 173.120 .

49 CFR Part 383.5

49 CFR Part 383.5

49 CFR Part 383.5 
3. the vehicle is used in the transportation of hazardous materials in a quantity requiring placarding under regulations issued by the Secretary under the Hazardous Materials Transportation Act (49 USC App. 18011813).49 CFR Part 390.5

Communication requirements

Compatibility group letter

Competent Authority

Compliance agreements

\footnotetext{
Compliance assurance
}

The requirements for providing a means to identify the material being transported and the hazards associated with the material. They include package markings and warning labels, vehicle placarding, and shipping documents.

A designated alphabetical letter used to categorize different types of explosive substances and articles for purposes of stowage and segregation.

(1) A national agency responsible under its national law for the control or regulation of a particular aspect of the transportation of hazardous materials (dangerous goods). The term "Appropriate Authority," as used in the International Cargo Aircraft Association Technical Instructions, has the same meaning as "Competent Authority." The Associate Administrator for Hazardous Materials Safety is the Competent Authority for the United States. (2) Any national or international authority designated or recognized as such for any purpose in connection with the International Atomic Energy Agency's Regulations for the Safe Transport of Radioactive Material.

Legally binding agreements between regulators and regulated entities that set standards and schedules for compliance with environmental statutes. Includes Consent Order Compliance, federal facilities, and federal facilities compliance agreements.

A systematic program of measures applied by a competent authority which is aimed at ensuring that the provisions of these Regulations are met in practice.
49 CFR Part 171.8

49 CFR Part 171.8; see also IAEA Safety Series 6.

IAEA Safety Series 6 
Composite

packaging

Comprehensive

Environmental

Response, Compensation, and Liability Act

Compressed gas

\section{Concentrated} load

Consignee

Consignment

Consignor
A packaging consisting of an outer packaging and inner receptacle, so constructed that the inner receptacle and the outer packaging form an integral packaging. Once assembled, it remains thereafter an integrated single unit; it is filled, stored, shipped, and emptied as such.

Federal statute (also known as Superfund) enacted in 1980 and reauthorized in 1986, that provides the statutory authority for cleanup of hazardous substances that could endanger the public health, welfare, or environment. Program activities include establishing the National Priorities List, investigating sites for inclusion on the list, determining their priority-level on the list, and conducting and/or supervising the ultimately determined cleanup and other remedial actions.

A gas or mixture of gases having, in a container, an absolute pressure exceeding $40 \mathrm{psi}$ at $70^{\circ} \mathrm{F}\left(21.1^{\circ} \mathrm{C}\right)$; a gas or mixture of gases having, in a container, an absolute pressure exceeding $104 \mathrm{psi}$ at $130^{\circ} \mathrm{F}$ $\left(54.4^{\circ} \mathrm{C}\right)$ regardless of the pressure at $70^{\circ} \mathrm{F}$ $\left(21.1^{\circ} \mathrm{C}\right)$; or a liquid having a vapor pressure exceeding $40 \mathrm{psi}$ at $100^{\circ} \mathrm{F}\left(37.8^{\circ} \mathrm{C}\right)$ as determined by ASTM D-323-72. Gases that are shipped under pressure. These can be nonflammable (e.g., nitrogen or helium) or flammable (e.g., hydrogen or butane). See also Poison A and Cryogenic liquid.

A defined weight in a defined span or localized area, whereas a distributed load is the same weight equally distributed over the entire length and width of the load-bearing upper surface of the semitrailer.

The person designated in the shipping papers to receive the shipment.

Any package or packages, or load of radioactive material, presented by a consignor for transport.

The person executing the shipping papers and named as such in the shipping papers. The consignor is in every case a shipper.
49 CFR Part 171.8

29 CFR Part

1910.1200

See also IAEA Safety Series 6.

IAEA Safety Series 6

See also IAEA Safety Series 6. 
Consumer
commodity

Contact-handled

Container

Containership

Containment requirements

Containment system

Contamination

Contamination control

Contamination control line
A material that is packaged and distributed in a form intended or suitable for sale through retail sales agencies or instrumentalities for consumption or use by individuals for personal care or household use. This term also includes drugs and medicines.

Radioactive containers that can be handled without shielding. (See Transuranic waste.)

Any type of drum, barrel, can, pail, box, cylinder, bag, bulk tank or vehicle, or other means of packaging hazardous materials.

A cargo vessel designed and constructed to transport, within specifically designed cells, portable tanks and freight containers which are lifted onto and off the vessel with their contents intact.

Requirements applicable to the features of a package (e.g., closures, seals, pressure-relief devices, packagecontent limits) which reduce the probability that material might be released to the environment during conditions normally incident to transport.

The components of the packaging intended to retain the radioactive contents during transportation.

The deposit and/or absorption of radioactive material and biological and chemical agents on and by structures, areas, personnel, or objects where it is undesirable.

Procedures to avoid, reduce, remove, or render harmless, temporarily or permanently, nuclear, biological, and chemical contamination for the purpose of maintaining or enhancing the efficient conduct of operations. .

The inner boundary of the contamination control station.
49 CFR Part 171.8

See also 29 CFR Part 1910.1200.

49 CFR Part 171.8
49 CFR Part 173.403; see also 10 CFR Part 71.4 and IAEA Safety Series 6.

See also IAEA Safety Series 6. 
Contamination control station

Controlled access

\section{Control requirements}

Conveyance

\section{Corrosive material}

Crate

Crew member

Critical mass
An area specifically designated for permitting ingress and egress of personnel and equipment to and from, respectively, the radiation control areas. The outer boundary of the contamination control station is the radiological control line, and inner boundary is the line segment labeled the contamination control line.

Roadways that are provided with either temporary or permanent physical access control barriers. Examples of physical barriers include fences, DOE- or contractor-controlled guard gates, and security road blocks. Use of passive barriers such as signs does not constitute providing controlled access.

Those operational steps or administrative measures taken to reduce the probability or consequence of an accident. These controls may include speed-limit restrictions, temporary road closures, or escorts.

(1) For transport by public highway or rail: any transport vehicle or large freight container; (2) for transport by vessel: any vessel, or any hold, compartment, or defined deck area of a vessel; and (3) for transport by aircraft: any aircraft.

Solids or liquids that destroy or severely damage skin or cause rapid corrosion of certain metals. Many acids, such as sulfuric acid, are corrosive to skin or steel, or to both.

An outer packaging with incomplete surfaces.

A person assigned to perform duty in an aircraft during flight time.

The smallest mass of fissionable material that will support a self-sustaining chain reaction under specified conditions.
49 CFR Part 171.8

49 CFR Part 173.403; see also 10 CFR Part 71.4 and IAEA Safety Series 6.

See also 49 CFR Part 173.136.

49 CFR Part 171.8 
Criticality

Criticality alarm

Cryogenic liquid

Curie

Cylinder

Decay

Decommissioning

Decontamination
A term used to describe the state of a given fission system when the specified conditions are such that the mass of active material present is precisely a critical mass. Thus, the fission neutron production rate is a constant and is exactly balanced by the combined rate of neutron loss and utilization so that the neutron population remains a constant. Supercriticality occurs when a greater than critical mass of active material is present and the neutron population increases rapidly.

A device incorporating a radiation detector and alarm circuitry placed at locations where significant quantities of fissionable material are handled or stored. At a preset value, the device triggers alarms indicating that high radiation is present at the detector probe and that a criticality accident may have occurred.

Gases that become liquids at extremely low (cryogenic) temperatures. Cryogenic liquids may be either flammable or nonflammable.

A unit measure of radioactivity; 1 curie (Ci) equals that quantity of any nuclide that undergoes $3.7 \times 10^{10}$ disintegrations per second. A millicurie (mCi) is onethousandth of a curie; a microcurie $(\mu \mathrm{Ci})$ is onemillionth of a curie, and a picocurie (pCi) is onebillionth of a curie.

A pressure vessel designed for pressures higher than 40 psia and having a circular cross section. It does not include a portable tank, multiunit tank-car tank, cargo tank, or tank car.

The spontaneous radioactive transformation of one nuclide into a different nuclide or into a lower energy state of the same nuclide. (See Nuclide)

The process of removing a facility from operation, followed by decontamination and then entombment, dismantlement, or conversion to another nonnuclear use.

The removal of unwanted material (especially radioactive material) from facilities, soils, or equipment by washing, chemical action, mechanical cleaning, or other techniques.
See also 49 CFR Part 173.115.

10 CFR Part 30.4; see also 40 CFR Parts 190.2 and 192.01 .

49 CFR Part 171.8 

Defined deck
area

\section{Depleted} uranium

Description

Design

Design basis

Design basis accidents

Design certifying engineer

Designated facility
The area, of the weather deck of a vessel, or of a vehicle deck of a roll-on/roll-off ship or a ferry, which is allocated for the stowage of radioactive material.

Uranium that has a smaller percentage of U-235 than the $0.7 \%$ found in natural uranium. It is found in some spent nuclear fuel or as by-product "tails" of uranium isotope separation.

Identification of a hazardous material by its proper shipping name, hazard class, identification number, and other information, such as a recognized chemical name.

The description of a special form material, a package or a packaging, that enables those items to be fully identified. The description may include specifications, engineering drawings, reports showing compliance with regulatory requirements, and other relevant documentation.

The set of functional requirements that bounds the design limits of process systems, components, equipment, or structures. These include plant availability, efficiency, reliability, and maintainability. Some aspects of the design basis are important to safety, while others are not.

Accidents that are postulated for the purpose of establishing functional requirements for safety significant structures, systems, components, and equipment.

A person registered with the U.S. Department of Transportation who has the knowledge and ability to perform stress analysis of pressure vessels and to otherwise determine if a cargo tank design and construction meet the applicable DOT specifications and who has an engineering degree and one year of work experience in structural or mechanical design. Persons registered as professional engineers by appropriate authority of a state of the United States, or a province of Canada, who have the requisite experience may be registered under this program.

A hazardous waste-treatment, storage, or disposal facility that has been designated on the manifest by the generator.
IAEA Safety Series 6

See also 49 CFR Part 173.403 and $10 \mathrm{CFR}$ Part 71.4.

49 CFR Part 173.403; see also IAEA Safety Series 6. 
Dismantlement

Disqualified

driver

Disposal

Distributed load

District

Commander

DOE Alternative

DOE Covered

Contractor
The removal of radioactive- and nonradioactivecontaminated equipment and materials from a facility to reduce the potential hazard to humans and to meet regulatory requirements.

A driver who has been convicted of an offense or is not qualified because of medical reasons, drug testing failure, expiration of any document in the driver's qualification files, or any other such qualifications as predetermined in the contractor's agreement with bargaining units.

Final placement or destruction of toxic or radioactive waste, surplus or banned pesticides or other chemicals; polluted soils, and drums containing hazardous materials from removal actions or accidental releases. Disposal may be accomplished through use of approved, secured, regulated landfills, surface impoundments, land farming, deep-well injection, or incineration.

A defined weight that bears essentially uniformly along the entire length and width of the load-bearing upper surface of the semitrailer.

The District Commander of the Coast Guard, or his authorized representative, who has jurisdiction in the particular geographical area.

A DOE document that authorizes DOE shipments of hazardous materials not in compliance with DOE orders.

A seller of supplies and services involving the packaging and transportation of hazardous materials under a procurement contract or a subcontract either of which (a) contains the clause entitled "Safety and Health" or (b) is performed in part on-site at a DOEowned or -leased facility and contains a provision asserting DOE's authority to enforce environmental protection, safety, and health requirements. The term "contract" does not include small purchases. 
DOE Orders

Domestic transportation

DOT Exemption

DOT labels

DOT placards

DOT specification marks

DOT specification number

DOT specification packaging

Drivers log

Driver qualification file

Drivers subject to testing
The means by which DOE identifies management objectives and requirements for DOE personnel. When incorporated into contracts, Orders establish requirements for DOE contractors. Orders are subject to all elements of the directives system. Orders may be changed through page changes or through complete revisions.

Transportation between places within the United States other than through a foreign country.

A DOT document that authorizes shipments of hazardous materials not in compliance with DOT regulations.

Labels required by DOT to be placed on packages of hazardous materials.

Devices, similar to DOT labels, used on the outside of vehicles and bulk containers transporting hazardous materials.

Marks which DOT requires to be placed on DOT specification packages, showing the DOT specification number and related information. (See UN Specification Marks.)

The number assigned by DOT to a type of DOT specification package.

Packaging fabricated in accordance with specification provided by the DOT.

A daily record of a driver's off-duty, on-duty-but-notdriving, and driving time and other information that serves to identify the motor carrier, the driver, and the nature of the driver's duties.

A file containing the documents specified by DOT for each employee who operates a commercial motor vehicle off-site.

Employee drivers and contract drivers under contract for $\mathbf{9 0}$ days or more in a period of $\mathbf{3 6 5}$ days. 
Driver's supervisor

Driver's time record

Driver training

Drum

Electron

Element

Elevatedtemperature material

Emergency plan
A line manager who directly supervises an individual responsible for operating a commercial motor vehicle.

A daily record showing (1) each time the driver reports for duty; (2) each time the driver is released from duty; (3) if applicable, the number of hours worked for compensation for an employer other than the contractor; and (4) the total number of hours worked.

A type of training designed for motor vehicle operators.

A flat- or convex-ended cylindrical packaging made of metal, fiberboard, plastic, plywood, or other suitable materials. This definition includes also packagings of other shapes made of metal or plastic (e.g., round taper-necked packagings or pail-shaped packagings), but does not include cylinders, jerricans, wooden barrels, or bulk packagings.

A negatively charged atomic particle. Electrons surround the atom's positively charged nucleus and determine the atom's chemical properties.

One of the 107 known chemical substances that cannot be divided into simpler substances by chemical means. The Periodic Table lists these elements. (Some examples: hydrogen, lead, uranium.)

A material which, when offered for transportation or transported in a bulk packaging: (1) is in a liquid phase and at a temperature at or above $100^{\circ} \mathrm{C}$ $\left(212^{\circ} \mathrm{F}\right),(2)$ is in a liquid phase with a flash point at or above $37.8^{\circ} \mathrm{C}\left(100^{\circ} \mathrm{F}\right)$ that is intentionally heated and offered for transportation or transported at or above its flash point, or (3) is in a solid phase and at a temperature at or above $240^{\circ} \mathrm{C}\left(464^{\circ} \mathrm{F}\right)$.

A brief, clear, and concise description of the overall emergency organization; designation of responsibilities; and procedures, including notification, involved in coping with any or all aspects of a potential credible emergency. 
Emergency
planning

Emergency

preparedness

Emergency

response

Emergency

Response

Guidebook

Emergency

response

information

Emergency

response

telephone

number

Encapsulated

Engine
The development and preparation of emergency plans and procedures and the identification of necessary personnel and resources to provide an effective response.

The training of personnel, acquisition and maintenance of resources, and exercising of the plans, procedures, personnel, and resources essential for emergency response.

The implementation of planning and preparedness during an emergency involving the effective decisions, actions, and application of resources that must be accomplished to mitigate consequences and recover from an emergency.

A book issued by DOT containing information of the potential hazards of hazardous materials and action to be taken in emergencies.

Information required to accompany a shipment of hazardous materials for use in emergencies.

Information required to be shown on the shipping paper specifying a telephone number that must be constantly monitored to provide access to persons with information useful in a transportation emergency.

A method of packaging consisting of a plastic sheet completely enclosing the sides and top of a palletload containing combustible commodities or combustible packages. Totally noncombustible commodities on wood pallets enclosed only by a plastic sheet as described are not considered to fall under this definition. Banding (e.g., stretch-wrapping around the sides only of a pallet load) is not considered to be encapsulated. The term "encapsulated" does not apply to individual plasticenclosed items inside a large, nonplastic-enclosed container.

A locomotive propelled by any form of energy and used by a railroad. 
Engineered barriers

Enriched
uranium

Enrichment

Entombment

Environmental assessment

Environmental impact statement

Environmental restoration

Ex number

Exclusive use (also referred as sole use or full load)
Features of a disposal site constructed of materials designed to isolate radioactive materials from the environment.

Uranium containing more uranium-235 than the naturally occurring distribution of uranium isotopes.

A process by which the natural ratios of the isotopes of a given element are altered.

The process of sealing or burying radioactively contaminated materials to prevent dispersion or intrusion.

A written environmental analysis which is prepared pursuant to the National Environmental Policy Act to determine whether a federal action would significantly affect the environment and thus require preparation of a more detailed environmental impact statement.

A document required of federal agencies by the National Environmental Policy Act for major projects or legislative proposals significantly affecting the environment. A tool for decision making, it describes the positive and negative effects of the undertaking and lists alternative actions. The report documents the information required to evaluate the environmental impact of a project. Such a report informs decision makers and the public of the reasonable alternatives which would avoid or minimize adverse impacts or enhance the quality of the environment.

Cleanup and restoration of sites contaminated with radioactive and hazardous substances during past DOE production activities.

A number, preceded by the prefix "Ex-," which is assigned by the Associate Administrator for Hazardous Materials Safety to identify an explosive that has been approved.

The sole use of a conveyance by a single consignor and for which all initial, intermediate, and final loading and unloading are carried out in accordance with the direction of the consignor or consignee.
49 CFR Part 173.403; see also 10 CFR Part 71.4 .
See also 49 CFR Part 387.5.

49 CFR Parts 171.8 and 173.56

49 CFR Part 173.403; see also 10 CFR Part 71.4 and IAEA Safety Series 6. 


\section{Explosives}

Facility

Familiarization training

Feasibility study

Feed materials

Field elements
Any loading or unloading must be performed by personnel having radiological training and resources appropriate for safe handling of the consignment. Specific instructions for maintenance of exclusive-use shipment controls must be issued in writing and included with the shipping-paper information provided to the carrier by the consignor.

Materials which can detonate or are subject to very rapid combustion. The most hazardous explosives are referred to as Class A Explosives, which includes nitroglycerin and large ammunition. Class $C$ Explosives, the least hazardous explosives, includes ordinary fireworks and small-arms ammunition. Explosives are assigned a classification code consisting of a division number followed by a compatibility group letter. (For example, a primary explosive substance is assigned classification code 1.1A.)

A term used to describe distinct DOE and/or contractor buildings, plants, multicomplex storage units, laboratories, and/or test ranges that are within fenced or otherwise access-controlled operating areas within the boundaries of a site.

See General Awareness and Familiarization Training.

Analysis of the practicability of a proposal, for example, a description and analysis of the potential cleanup alternatives for a site on the National Priorities List. The feasibility study frequently recommends selection of a cost-effective alternative. It frequently starts as soon as the remedial investigation is under way; together, they are commonly referred to as the "RI/FS." The term can apply to a variety of proposed corrective or regulatory actions.

Refined uranium or thorium metal or their pure components in a form suitable for use in nuclear reactor fuel elements or as feed to uranium enrichment facilities.

All DOE activities that are not located at the headquarters at Germantown, Maryland or Washington, D.C.
See also 49 CFR Part 173.50 and 29 CFR Part 1910.1200. 
Fissile

classification

Fissile material

Fission

Fixed

contamination

Flammable liquid

Flammable solid

Flash point

Forbidden
materials

Formerty

Utilized Sites

Remedial Action

Program

Freight container
Classification of a package or shipment of fissile materials according to the controls needed to provide nuclear criticality safety during transportation.

Any material consisting of or containing one or more fissile radionuclides. Fissile radionuclides are $\mathrm{Pu}-238$, $\mathrm{Pu}-239, \mathrm{Pu}-241, \mathrm{U}-233$, and U-235. Neither natural nor depleted uranium is fissile material.

The splitting of a heavy nucleus into two roughly equal parts (which are nuclei of lighter elements), accompanied by the release of a relatively large amount of energy and frequently one or more neutrons. Fission can occur spontaneously, but usually it is caused by the absorption of gamma rays, neutrons, or other particles.

Contamination that can not be removed from a surface during normal handling

Liquids (such as gasoline) that can ignite at relatively low temperatures.

Solids, including water-reactive or spontaneously combustible solids. Included are certain metals (such as lithium) or metal powders and certain types of matches.

The minimum temperature at which a substance gives off flammable vapors which, in contact with sparks or flame, will ignite.

Hazardous materials that are not allowed to be offered for transportation or transported in one or more types of transportation.

A program under the direction of the Office of Environmental Restoration and Waste Management that addresses the cleanup of sites and adjacent properties contaminated by activities of the Manhattan Project.

A reusable container having a volume of 1.81 cubic meters $\left(64 \mathrm{ft}^{3}\right)$ or more, designed and constructed to permit its being lifted with its contents intact and intended primarily for containment of packages in
See also 10 CFR Part 71.4.

49 CFR Part 173.403; see also 49 CFR Part 173.453 and 455, 10 CFR Part 71.4, and IAEA Safety Series 6.

See also 49 CFR Part 173.120 and 29 CFR Part 1910.1200.

See also 49 CFR Part 173.124 and 29 CFR Part 1910.1200.

49 CFR Part 173.120; see also 29 CFR Part 1910.1200.

49 CFR Part 173.403; see also IAEA Safety Series 6. 
Fuel tank

Function-specific training

\section{Gamma ray}

Gas

Gas-leakage test methodology

Gaseous

diffusion

Geologic repository unit form during transportation. A small freight container is one which has either one outer dimension less than $1.5 \mathrm{~m}$ ( $4.9 \mathrm{ft}$ ) or an internal volume of not more than $3 \mathrm{~m}^{3}\left(106 \mathrm{ft}^{3}\right)$. All other containers are designated as large freight containers.

A tank other than a cargo tank, used to transport flammable or combustible liquid, or compressed gas for the purpose of supplying fuel for propulsion of the transport vehicle to which it is attached, or for operating other equipment on the transport vehicle.

49 CFR Part 171.8
Instruction or training concerning the hazardous material rules that apply to the activities of a specific job.

High-energy, short-wavelength, electromagnetic radiation emitted by a nucleus during radioactive decay. Gamma rays are very penetrating and are best blocked by dense materials like lead and depleted uranium. X-rays, although of nonnuclear origin, also occur in this same energy range, as do ultraviolet rays. Gamma radiation is usually accompanied by alpha and beta radiation, and always accompanies fission.

\section{See Compressed gas.}

A method of specifying a gas leakage rate test which relates permissible activity release rates of the radioactive contents carried within a containment system to equivalent gas-leakage rates under specified test conditions.

A technology for separating fissionable U-235 isotopes from the more abundant nonfissionable uranium isotopes by pumping gaseous uranium hexafluoride through resistant barriers.

A mined facility for disposal of radioactive wastes that uses natural geologic barriers to provide waste containment for geologic time periods (millions of years). 
Government aircraft

Gross combination weight rating

Gross vehicle weight rating

Gross weight or gross mass

Groundwater

Groundwater remediation

Grout

Half-life

Hazard Class
An aircraft used exclusively in the service of any government or of any political subdivision thereof, including the government of any state, territory, or possession of the United States, or the District of Columbia, but not including any government-owned aircraft engaged in carrying persons or property for commercial purposes.

The value specified by the manufacturer as the loaded weight of a combination (articulated) vehicle. In the absence of a value specified by the manufacturer, the gross combination weight rating will be determined by adding the gross combination weight rating of the power unit and the total weight of the towed unit and any load thereon.

The value specified by the manufacturer as the loaded weight of a single vehicle.

The weight of a packaging plus the weight of its contents.

Water that exists or flows in a zone of saturation beneath land surface; liquid occurring beneath the earth's surface, in the interstices between soil grains, in fractures, or in porous formations.

Treatment of groundwater to remove pollutants.

A cement-like substance used to solidify and immobilize liquid low-level radioactive waste for disposal or to stabilize disposal trenches.

Time required for a radioactive substance to lose $50 \%$ of its radioactivity by decay. After a period equal to 10 half-lives, the radioactivity has decreased to about $0.1 \%$ of its original value. (See Alpha particle, Beta particle, and Gamma ray.)

The category of hazard assigned to a hazardous material. A material may meet the defining criteria for more than one hazard class but is assigned to only one hazard class.
49 CFR Part 383.5; see also 49 CFR Part 390.5 .

49 CFR Part 383.5; see also 49 CFR Part 390.5 .

49 CFR Part 171.8

49 CFR Part 171.8 
Hazard

Communication

Standard

\section{Hazard \\ Information \\ Transmission}

Hazard warning

Hazard zone

Hazardous

chemicals

Hazardous material

Hazardous materials

employee
The Occupational Safety and Health Administration standard that is cited in 29 CFR Part 1910.1200. The standard requires the communication of hazards and risks of hazardous substances to workers that may be exposed to these hazards.

This program provides digital transmission of a Chemical Transportation Emergency Center emergency chemical report to first responders on the scene of hazardous materials incidents; also advises responders on hazards of the materials, level of protective clothing, mitigating action and aid of victims.

Any words, pictures, symbols, or combination thereof appearing on a label or other appropriate form of warning which convey the hazard(s) of the chemical(s) in the container(s).

One of four levels of hazard (Hazard Zones A through D) assigned to gases, and one of two levels of hazards (Hazard Zones A and B) assigned to liquids that are poisonous by inhalation. $A$ hazard zone is based on the $\underline{L C}_{S_{0}}$ value for acute inhalation toxicity of gases and vapors.

All chemicals which constitute a physical hazard or a health hazard.

29 CFR Part 1910.1200

49 CFR Parts 171.8 and 390.5

A substance or material which has been determined by the Secretary of Transportation to be capable of posing an unreasonable risk to health, safety, and property when transported in commerce, and which has been so designated. The term includes hazardous substances, hazardous wastes, marine pollutants, and elevated-temperature materials.

A person who is employed by a hazardous materials employer and who in the course of employment directly affects hazardous materials transportation safety. This term includes a person employed by a hazardous material employer who, during the course of employment,

1. loads, unloads, or handles hazardous materials; 
Hazardous materials employer

Hazardous Materials Information Exchange

Hazardous Materials Regulations

Hazardous Materials Table
2. tests, reconditions, repairs, modifies, marks, or otherwise represents containers, drums, or packagings as qualified for use in the transportation of hazardous materials;

3. prepares hazardous materials for transportation;

4. is responsible for safety of transporting hazardous materials; or

5. operates a vehicle used to transport hazardous materials.

A person or company which uses one or more of its 49 CFR Part 171.8 employees in connection with transporting hazardous materials in commerce; causing hazardous materials to be transported or shipped in commerce or which represents, marks, certifies, sells, offers, reconditions, tests, repairs, or modifies containers, drums, or packagings as qualified for use in the transportation of hazardous materials. This term includes an owneroperator of a motor vehicle which transports hazardous materials in commerce. This term includes also any department, agency, or instrumentality of the United States, a state, a political subdivision of a state, or an Indian tribe engaged in an activity described in the first sentence of this definition.

A national data repository and "bulletin board" for all states' use regarding planning, available training courses, regional activities and events, and recent legislation or regulation updates. It is available to any communications-capable personal computer by dialing directly to (312)972-3275. Currently, the exchange is operated by Argonne National Laboratory, under contract.

Those parts of 49 CFR (specifically Parts 106-190) related to the transport of hazardous materials.

A table that lists and classifies those materials which DOT has designated as hazardous materials for purposes of transportation. The table prescribes the requirements for shipping papers, package marking, labeling, and transport vehicle placarding applicable to the shipment and transportation of those hazardous materials. 
Hazardous

substances

Hazardous waste

Hazardous

Waste Manifest

Headquarters

Certifying

Official

Headquarters

elements

Hermetically

sealed

High-level waste
Materials identified by the U.S. Environmental Protection Agency as environmentally hazardous.

Any material defined and regulated as such by the Environmental Protection Agency regulation. As defined in the 1976 Resource Conservation and Recovery Act, a solid waste, or combination of solid waste, that because of its quantity or concentration or physical, chemical, or infectious characteristics, (a) may cause or significantly contribute to an increase in mortality or an increase in serious, irreversible, or incapacitating reversible illness or (b) pose a substantial present or potential hazard to human health or the environment when improperly treated, stored, transported, disposed of, or otherwise managed.

\section{See Shipping paper.}

The designated Headquarters Official responsible for administering the U.S. Department of Energy program for the certification of Type $B$ and the review and approval of fissile, Type 7A, and specialform packagings.

\section{Cognizant Secretarial Officers and Secretarial} support officers located at Washington, D.C. and Germantown, Maryland.

Closed by fusion, gasketing, crimping, or equivalent means so that no gas or vapor can enter or escape.

The highly radioactive waste material that results from the reprocessing of spent nuclear fuel, including liquid waste produced directly in reprocessing and any solid waste derived from the liquid, that contains a combination of transuranic waste and fission products in concentrations high enough such as to require permanent isolation. It also includes other highly radioactive material that the Nuclear Regulatory Commission, consistent with existing law, determines to require permanent isolation.
See also 49 CFR Parts 171.8 and 390.5 .

See also 49 CFR Part 390.5 and 40 CFR Parts 240.101 and 261.3.

49 CFR Part 171.8

See also 40 CFR Part 191.02. 
Highway-routecontrolled quantity

HM-181

HM column

Identification

codes for

packagings
A quantity within a single package which exceeds

49 CFR Part 173.403

(1) 3000 times the $A_{1}$ value of the radionuclides as specified for special-form radioactive material;

(2) 3000 times the $A_{2}$ value of the radionuclides as specified for normal-form radioactive material; or (3) 30,000 curies, or whichever is least.

The number assigned to the hearing in which the DOT considered adopting many of the international hazardous materials transportation rules for use in the United States.

A part of a shipping paper used to identify the hazardous materials entries on the paper by placing an " $\mathrm{X}$ " or, when appropriate, the letters " $\mathrm{RQ}^{\text {" in the }}$ column alongside such entries.

Identification codes for designating types of packagings consist of the following:

1. An arabic numeral indicating the type of packaging, as follows:

- 1 is a drum

- 2 is a wooden barrel

- 3 is a jerrican

- 4 is a box

- 5 is a bag

- 6 is a composite packaging

- 7 is a pressure receptacle

2. A capital letter indicating the material of construction, as follows:

- $A$ is steel (all types and surface treatments)

- $B$ is aluminum

- $C$ is natural wood

- D is plywood

- $F$ is reconstituted wood

- $G$ is fiberboard

- $\mathrm{H}$ is plastic

- $\mathbf{L}$ is textile

- $M$ is paper, multiwall

- $\mathbf{N}$ is metal (other than steel or aluminum)

- $\mathbf{P}$ is glass, porcelain or stoneware 
Identification number

Inactive waste site

Incineration

\section{Industrial hygiene}

Industrial hygiene program

Inhalation hazard Inner packaging
3. A numeral indicating the category of packaging within the type to which the packaging belongs. For example, for steel drums (" $\left.1 \mathrm{~A}^{n}\right)$, "1" indicates a nonremovable head drum (i.e., "1A1") and " 2 " indicates a removable head drum (i.e., "1A2").

4. For composite packagings, two capital letters used in sequence in the second position of the code, the first indicating the material of the inner receptacle and the second, that of the outer packaging. For example, a plastic receptacle in a steel drum is designated "6HA1."

5. For combination packagings, only the code number for the outer packaging is used.

The four-digit number on a placard or the four digit number (after UN/NA) on a shipping paper or package.

Site formerly used for the treatment, storage, or disposal of waste.

A treatment technology using combustion to destroy organic constituents and reduce the volumes of waste, for example burning sludge to remove the water and reduce the remaining residues to a safe, nonburnable ash which can be disposed of safely on land or in underground locations.

The occupational health science and art devoted to the recognition, evaluation, and control of environmental factors or stresses arising in or from the work place that may cause sickness, impaired health and well being, or significant discomfort and inefficiency among workers or those with whom they are in contact.

The implementation of a written systematic plan to recognize, evaluate, control, and document exposer to health hazards in the environment.

See Poison inhalation hazard.

A packaging for which an outer packaging is required for transport. It does not include the inner receptacle of a composite packaging.
49 CFR Part

172.101(e)

See also 40 CFR Part 240.101. 
Inner receptacle

Interim Hazard Classification

Intermodal container

Intermodal portable tank

International Air

Transport

Association

International Air

Transport

Association rules

International Civil Aviation Organization

International Civil Aviation Organization rules

International Maritime Dangerous Goods Code

Intemational Maritime Organization
A receptacle which requires an outer packaging in

49 CFR Part 171.8 order to perform its containment function. The inner receptacle may be an inner packaging of a combination packaging or the inner receptacle of a composite packaging.

A DOE document that includes identification of the new explosive substance, the DOT classification, hazard communication information, expiration date, and approval signature.

A freight container designed and constructed to permit it to be used interchangeably in two or more modes of transport.

A specific class of portable tanks designed primarily for international intermodal use.

49 CFR Part 171.8
49 CFR Part 171.8

A world organization of airlines.

The regulations issued by the International $\mathrm{Air}$ Transportation Association for air transportation of hazardous materials.

An international organization of governments concerned with air transportation.

The regulation issued by the International Civil Aviation Organization for air transportation of hazardous materials. The International Civil Aviation Organization rules are incorporated into the International Air Transportation Association Rules.

The International Maritime Dangerous Goods Code issued by the International Maritime Organization for water transportation of hazardous materials.

An international organization of governments concerned with water transportation. 
International transportation

Interstate commerce

Intrastate commerce

Irradiated reactor fuel

Irradiation

Irritating material

Isolation

Isotope

Jerrican
Transportation-between

49 CFR Part 171.8

1. any place in the United States and any place in a foreign country,

2. in the United States through a foreign country, or

3. places in one or more foreign countries through the United States.

Trade, traffic, or transportation in the United States which is between a place within a state and a place outside of such state (including a place outside of the United States) or is between two places in a state through another state or through a place outside of the United States.

Any trade, traffic, or transportation in any state which is not described in the term "interstate commerce."

\section{See Spent nuclear fuel.}

Exposure to radiation of wavelengths shorter than those of visible light (gamma, $\mathrm{x}$-ray, or ultraviolet).

Solids or liquids that emit very irritating fumes under certain circumstances.

The placement of radioactive waste so that contact between the waste and humans or the environment will be highly unlikely for a chosen period of time.

Atoms with the same atomic number (same chemical element) but different atomic weights. In other words, the nuclei have the same number of protons, but a different number of neutrons. (See Element, Atom.)

A metal or plastic packaging of rectangular or polygonal cross-section. 
Land disposal restrictions

Landfills

Leak

Leakage

Leakage rate

Leak-tight

Licensee (akso NRC Licensee)

Limited access area
Provisions of the Hazardous and Solid Waste Amendments to the Resource Conservation and Recovery Act that apply to hazardous waste placed in storage or disposed of after November 7, 1986. Land Disposal Restrictions prohibit the placement in or on the land of listed or characteristic hazardous waste that does not meet specified standards.

Sanitary landfills are land disposal sites for nonhazardous solid waste. The waste is spread in layers and compacted to the smallest reasonable volume and cover material is applied at the end of each operation-day. Secured chemical landfills are disposal sites for hazardous waste. They are selected and designed to minimize the chance of release of hazardous substances into the environment.

Any unwanted opening or openings throughout a containment system that could permit the escape of the contents.

Transfer of a material from the containment system to the environment through a leak or leaks.

Leakage rate is defined as the quantity of solid particles, liquids or gases passing through leaks per unit time. The term leakage rate can refer to the radioactive material (gas, liquid, solid, or any mixture of these) or to the test fluid. The dimensions of the rate of solid leakage are mass divided by time. The dimensions of the rate of liquid leakage can be mass divided by time or volume divided by time. The dimensions of the rate of gas leakage are the product of pressure and volume (this is a mass-like unit) divided by time.

A general term indicating that a containment system meets the required level of containment for particular contents.

A person who is authorized to conduct activities under a license issued by the NRC.

10 CFR Part 19.5 and 10 CFR Part 2.4
Areas on federal property where public access is controlled through the use of posted signs. 
Limited quantity The maximum amount of a hazardous material for

49 CFR Part 171.8 which there is a specific labeling or packaging exception.

Limited quantity of radioactive material

Limited quantity shipments

Liquid

Liquid phase

Local law enforcement agency
A quantity of radioactive material not exceeding the

49 CFR Part 173.403 materials package limits as specified in 49 CFR Part 173.423 and which conform with requirements as specified in 49 CFR Part 173.421.

Shipments of certain types of hazardous materials in small containers specified in the hazardous material rules. Such shipments are allowed certain exceptions-such as an exception from the labelling requirements of the hazardous material regulations.

A material that has a vertical flow of over 2 in. (50 $\mathrm{mm}$ ) within a 3-min period, or a material having one gram or more liquid separation when determined in accordance with the procedures specified in American Society for Testing and Materials D 4359-90, "Standard Test Method for Determining Whether a Material is a Liquid or Solid," 1990 edition.

A material that meets the definition of "liquid" when evaluated at the higher of the temperatures at which it is offered for transportation or at which it is transported, not at the $37.8^{\circ} \mathrm{C}\left(100^{\circ} \mathrm{F}\right)$ temperature specified in American Society for Testing and Materials D 4359-90, "Standard Test Method for Determining Whether a Material is a Liquid or Solid," 1990 edition.

Any state, county, or municipal agency having law enforcement authority within the locality or jurisdiction. The term includes county or municipal police forces, port authority police, railroad special agents, highway patrol, etc. In some instances, involving sea shipments, for example, the U.S. Coast Guard or other federal agencies may also be considered as the local law enforcement agency, depending upon their authority to provide a response to a request for assistance.
49 CFR Part 171.8

49 CFR Part 171.8 
Locomotive crane

Low-level waste

Low-specificactivity material

Magazine vessel

Manhattan
Project

Marine pollutant
A rotating superstructure with power plant, operating machinery, and boom, mounted on a base or car equipped for travel on railroad track. It may be selfpropelled or propelled by an outside source. Its function is to hoist and swing loads at various radii.

Radioactive waste not classified as high-level waste, transuranic waste, spent nuclear fuel, or by-product material.

Any of the following: (1) uranium or thorium ores and physical or chemical concentrates of those ores; (2) unirradiated natural or depleted uranium or unirradiated natural thorium; (3) tritium oxide in aqueous solutions provided the concentration does not exceed $5 \mathrm{mCi}$ per $\mathrm{mL}$; (4) material in which the radioactivity is essentially uniformly distributed and in which the estimated average concentration of contents does not exceed (i) $0.0001 \mathrm{mCi}$ per $\mathrm{g}$ of radionuclides for which the $A_{2}$ quantity is not more than $0.05 \mathrm{Ci}$; (ii) $0.005 \mathrm{mCi}$ per $\mathrm{g}$ of radionuclides for which the $A_{2}$ quantity is more than $0.05 \mathrm{Ci}$, but not more than $1 \mathrm{Ci}$, or (iii) $0.3 \mathrm{mCi}$ per $\mathrm{g}$ of radionuclides for which the $A_{2}$ quantity is more than $1 \mathrm{Ci}$; (5) objects of nonradioactive material externally contaminated with radioactive material, provided that the radioactive material is not readily dispersible and the surface contamination, when averaged over and area of $1 \mathrm{sq} \mathrm{m}$, does not exceed $0.0001 \mathrm{mCi}$ $(220,000 \mathrm{dpm})$ per sq $\mathrm{cm}$ of radionuclides for which the $A_{2}$ quantity is not more than $0.05 \mathrm{Ci}$, or $0.001 \mathrm{mCi}(2,200,000 \mathrm{dpm})$ per sq $\mathrm{cm}$ for other radionuclides.

A vessel used for the receiving, storing, or dispensing of explosives.

The U.S. government top-secret program to produce an atomic bomb for use during World War II.

A hazardous material which is listed in appendix B to 49 CFR Part 172.101 of this subchapter and, when in a solution or mixture of one or more marine pollutants, is packaged in a concentration which equals or exceed:
49 CFR Part 173.403; see also 10 CFR 71.4 and IAEA Safety Series 6.

49 CFR Part 171.8

49 CFR Part 171.8 
1. $10 \mathrm{wt} \%$ of the solution or mixture for materials listed in the appendix; or

2. 1 wt\% of the solution or mixture for materials that are identified as severe marine pollutants in the appendix.

Marking

Marks

Materials poisonous by inhalation

Material Safety Data Sheet

Maximum
capacity
Maximum net
maxs
Maximum
normal operating
pressure

Maximum

Maximum net maxs The allowable maximum net mass of contents in a single packaging, or the maximum combined mass of inner packaging and the contents thereof.

The maximum pressure above atmospheric pressure at mean sea-level that would develop in the containment system in a period of one year under the conditions of temperature and solar radiation corresponding to environmental conditions of transport in the absence of venting, external cooling by an ancillary system, or operational control during transport.
49 CFR Part 171.8

See also 29 CFR Part 1910.1200.

49 CFR Part 171.8

49 CFR Part 171.8; see also 49 CFR Part 178 Subpart $M$.

IAEA Safety Series 6; see also 10 CFR Part 71.4. 
Mixed waste

Mixture

Mode

Molecular flow

Monitoring

Motor carrier

Motor vehicle

Multilateral approval
Waste that contains both radioactive and hazardous components as defined by the Atomic Energy Act and the Resource Conservation and Recovery Act.

A material composed of more than one chemical compound or element.

Any of the following transportation methods: rail, highway, air, or water.

The flow of gas through a leak under conditions such that the mean free path is greater than the largest dimension of a transverse section of the leak.

Periodic or continuous measuring of the quantity and type of discharges or migration of radioactive waste from a managed facility to determine the level of compliance with statutory requirements and/or pollutant levels in various media.

A common, contract, or private carrier of a property by motor vehicle.

Any vehicle, trailer, or semitrailer that is propelled or drawn by mechanical power and used upon the highways in the transportation of passengers or property, or any locomotives or cars operated exclusively on rail or rails.

Approval by both the appropriate competent authority of the country of origin and of each country though or into which the shipment is to be transported. This definition does not imply approval from countries over which radioactive materials are carried in aircraft if there is no scheduled stop in that country.
49 CFR Part 171.8; see also 29 CFR Part 1910.1200.

49 CFR Part 171.8
49 CFR Part 387.3; see also 49 CFR Parts $386.2,390.5$ and 391.85 .

See also 49 CFR Parts $171.8,383.5$, and 390.5 .

49 CFR Part 173.403; see also IAEA Safety Series 6. 
Multipurpose canister

Name of contents

National Emission Standards for Hazardous Air Pollutants

National Environmental Policy Act of 1969

National

Pollutant

Discharge

Elimination

System

National Priorities List
The multi-purpose canister is a single triple-purpose sealed container for spent nuclear fuel (SNF) which provides handling and other capabilities for dry storage, transportation, and disposal activities. Multipurpose canisters are provided with two lids, welded to the container, which provide a dry environment for SNF and are overpacked separately and uniquely for the various system elements of storage, transportation, and geologic disposal.

The proper shipping name as specified in 49 CFR Part 172.101.

The Clean Air Act establishes limits on the release of hazardous pollutants for which no ambient air quality standard is applicable. Under the March 7, 1989, proposed ruling, National Emission Standards for Hazardous Air Pollutants will also address radioactive releases to the air.

The Act which established the requirements for conducting environmental reviews of federal actions that have the potential for significant impact on the human environment.

A provision of the Federal Water Pollutants Control Act (also known as Clean Water Act) which prohibits discharge of pollutants into waters of the United States unless a special permit is issued by the Environmental Protection Agency, a state, or (where delegated) a tribal government on an Indian reservation.

The Environmental Protection Agency's list of the most serious uncontrolled or abandoned hazardous waste sites identified for possible long-term remedial action under the Comprehensive Environmental Response, Compensation, and Liability Act (Superfund). A site must be on the National Priorities List to receive money from the Trust Fund for remedial action. The list is based primarily on the score a site receives from the Hazard Ranking System. The Environmental Protection Agency is required to update the National Priorities List at least once a year. 
Natural thorium Thorium with the naturally occurring distribution of thorium isotopes (essentially 100 weight-percent Th-232).

Natural uranium

Navigable waters

Neutron

Neutron poisons

Nonbulk packaging

Nonfixed radioactive contamination

\section{Normal conditions of transport}

Normal-form radioactive material
Uranium with the naturally occurring distribution of uranium isotopes (approximately 0.711 weightpercent U-235 and the remainder essentially U-238).

Waters of the United States, including the territorial seas that maintain open passageways for marine traffic.

An uncharged nuclear particle roughly equal in weight to a proton; one of the two principal components of a nuclei. Neutrons sustain the fission chain reaction in a nuclear reactor. (See Fission.)

Materials other than fissile material which will absorb neutrons (such as boron, cadmium, or gadolinium).

A packaging which has

1. a maximum capacity $450 \mathrm{~L}$ (119 gal) or less as a receptacle for a liquid;

2. a maximum net mass of $400 \mathrm{~kg}$ (882 lb) or less and a maximum capacity of $450 \mathrm{~L}(119 \mathrm{gal})$ or less as a receptacle for a solid; or

3. a water capacity of $454 \mathrm{~kg}(1000 \mathrm{lb})$ or less as a receptacle for a gas.

Radioactive contamination that can be readily removed from a surface by wiping with an absorbent material. Nonfixed (removable) radioactive contamination is not significant if it does not exceed the limits specified.

The normal conditions of transport are those used as described in the NRC regulations for evaluation of package design.

Radioactive material which has not been demonstrated to qualify as "special form radioactive material."
49 CFR Part 173.403; see also 10 CFR Part 71.4.

See also 49 CFR Part 171.8 .

See also 49 CFR Part 171.8.

49 CFR Part 173.403; see also 49 CFR Part 173.443 .

10 CFR Part 71.71; see also IAEA Safety Series 6.

49 CFR Part 173.403; see also 10 CFR Part 71.4 . 
Nonreusable

container

Nuclear fuel

Nuclear fuel cycle

Nuclear fuel element

Nuclear fuel fabrication

Nuclear fuel reprocessing plant

Nuclear radiation

Nuclear reactor

Nuclear Waste Fund
A packaging (container) whose reuse is restricted.

Fissionable material used as a source of power when placed in a specific arrangement in a nuclear reactor.

The complete series of steps involved in supplying fuel for nuclear reactors. It includes mining, refining, enrichment, fabrication of fuel elements, use in a reactor, chemical processing to recover the fissionable material remaining in the spent fuel, reenrichment of the fuel material, refabrication of fuel elements, and management of radioactive waste.

A tube, rod, or other form into which fuel material is fabricated for use in a reactor.

The process through which fissionable metal is configured into precisely shaped fuel or target elements and clad in lead or other materials to be made ready for use in a reactor.

A chemical plant where irradiated spent-nuclear-fuel elements are processed to separate fission products from uranium and plutonium.

Particulate and electromagnetic radiation emitted from nuclei. (See Alpha particle, Beta particle, Gamma ray, and Neutron.)

An assembly of nuclear fuel capable of starting and sustaining a controlled chain reaction based on nuclear fission.

A fund established by the Nuclear Waste Policy Act of 1982, which directed the Department of Energy to pursue a program toward disposal of commercial high-level and spent fuel waste, and defense highlevel waste in a geologic repository. The nuclear waste fund assesses utilities a fee to pay for siting, development, and operation of a commercial repository. The share of the costs commensurate with the portion of the repository committed for disposal of defense high-level waste will be paid by the Department of Energy.
49 CFR Part 171.8; see also 49 CFR Part 173.28.

See also 40 CFR Part 190.02 .

See also $40 \mathrm{CFR}$ Part 190.02 . 
Nuclear Waste

Policy Act

Nucleus

Nuclide

\section{Occupied}

caboose

Offsite facility

Onsite facility

Officer in

Charge, Marine

Inspection

Offshore supply vessel

Offite

Onsite
An Act passed in 1982 and reauthorized in 1987 that directs the Department of Energy to design, site, and construct a geologic repository for the disposal of defense high-level radioactive waste and spent fuel from civilian (commercial) nuclear reactors. The Act also established the Office of Civilian Radioactive Waste Management to carry out these responsibilities.

The small positively charged core of an atom that contains nearly all of the atom's mass and that consists of protons and neutrons except in hydrogen which consists of one proton only.

Any species of an atom that exists for a measurable length of time. A radionuclide is a radioactive nuclide. Radionuclides emit alpha, beta, and/or gamma rays, depending on their composition. (See Alpha particle, Beta particle, and Gamma ray.)

A rail car being used to transport nonpassenger personnel.

49 CFR Part 171.8

A hazardous waste treatment, storage, or disposal area that is located at a place away from the generating site.

A hazardous waste treatment, storage, or disposal area that is located at the generating site.

A person from the civilian or military branch of the 49 CFR Part 171.8 Coast Guard designated as such by the Commandant and who under the supervision and direction of the Coast Guard District Commander is in charge of a designated inspection zone for the performance of duties with respect to the enforcement and administration of Title 52, Revised Statutes.

A cargo vessel of less than $\mathbf{5 0 0}$ gross tons that regularly transports goods, supplies or equipment in 49 CFR Part 171.8 support of exploration or production of offshore mineral or energy resources.

Any area within or outside a DOE site to which the public has free and unlimited access.

Any area within.the boundaries of a DOE site or facility that is fenced or otherwise access-controlled. 
Operator

Organic peroxide

Organic peroxide

Generally
peroxide.

A person who controls the use of an aircraft, a vessel, or a vehicle.

49 CFR Part 171.8

49 CFR Part 171.8; see also 49 CFR Part 173.128 and 29 CFR Part 1910.1200.
Orientation marks

Originator

Other Regulated Materials

Outage or ullage

Outer packaging

Overpack

Oxidizer

Package

Package marks

Packaging
Package marks indicating which part of the package must be kept upright (i.e., "This End Up").

An individual or group that prepares a consignment of material for shipment off-site or transfer on-site.

A category of hazardous materials, consisting of five subcategories, referred to as ORM-A, ORM-B, ORM-C, ORM-D, and ORM-E.

The amount by which a packaging falls short of being liquid full, usually expressed in percent by volume.

The outermost enclosure of a composite or combination packaging together with any absorbent materials, cushioning, and any other components necessary to contain and protect inner receptacles or inner packagings.

An enclosure that is used by a single consignor to provide protection or convenience in handling of a package or to consolidate two or more packages.

"Overpack" does not include a freight container.

Materials that give off oxygen which can stimulate burning. Many peroxides are oxidizers, as are some cosmetics.

Packaging with contents as presented for transport.

Information required to be placed on containers of hazardous materials.

The assembly of components necessary to contain and transport hazardous materials. It may consist of one or more receptacles, absorbent materials, spacing structures, thermal insulation, radiation shielding,
See also 49 CFR Parts 171.8 and 173.144.

49 CFR Part 171.8

49 CFR Part 171.8

49 CFR Part 171.8; see also 49 CFR Part 178 and IAEA Safety Series 6.

See also 29 CFR Part 1910.1200 and

49 CFR Part 173.127.

See also 49 CFR Parts 171.8 and 173.403 , 10 CFR Part 71.4, and IAEA Safety Series 6.

10 CFR Part 71.4; see also 49 CFR Parts 171.8 and 173.403 . 


\section{Packaging technology}

Packing group

Packing group number

Permit

Person passive devices for cooling or for absorbing mechanical shocks, external fittings, neutron moderators, nonfissile neutron absorbers, and other supplementary equipment. (See Containers; also Specification package.)

All technology underlying the design, development, testing and operation of a materials packaging systems. Base technology elements include:

(a) generic design concepts and components with potential for future systems applications;

(b) maintenance and bench-marking of test facilities;

(c) activities related to increased understanding of materials and their applications to package design;

(d) characterization of authorized package contents;

(e) risk and accident analysis methods;

(f) environmental impact analysis methods;

(g) standards development; (h) technical investigations into adequacy of regulations and need for revision of regulations; (i) development and application of computer codes for design and system analysis; (j) development and application of data bases; and (k) supporting research in the physical, chemical, mathematical, and engineering sciences.

A grouping according to the degree of danger presented by hazardous materials. Packing Group I indicates great danger; Packing Group II, moderate danger; Packing Group III, minor danger.

A number (I, II, or III), indicating whether a packaging may be used for products that are considered very dangerous (PG I), moderately dangerous (PG II), or of minor danger (PG III).

An authorization, license, or equivalent control document issued by the Environmental Protection Agency or an approved state agency to implement the requirements of an environmental regulation; for example, a permit to operate a wastewater treatment plant or to operate a facility that may generate harmful emissions.

An individual, firm, copartnership, corporation, company, association, joint-stock association, including any trustee, receiver, assignee, or similar representative thereof, or government, Indian tribe, or agency or instrumentality of any government or
49 CFR Part 171.8; see also 49 CFR Part 172.101. 
Indian tribe when it offers hazardous materials for transportation in commerce or transports hazardous materials in furtherance of a commercial enterprise, but such term does not include:

1. the United States Postal Service or

2. any agency or instrumentality of the federal government.

Placarded car

Placards

Plutonium

Poison A

Poison B

Poison-inhalation hazard
A rail car which is placarded in accordance with the regulations, except those cars displaying only the FUMIGATION placards.

\section{See DOT placards.}

A radioactive element with an atomic number of 94. Its most important isotope is fissionable plutonium239 , which is produced by neutron irradiation of uranium-238. (See Neutron, Irradiation, and Isotope.)

Gases whose vapors can be very dangerous to life. Phosgene (sometimes called "Mustard Gas") is a Poison A material. Under the hazardous materials regulations, these gases are in Hazard Class Division 2.3, poisonous gas.

Materials, such as arsenic, that are dangerous to health because of their known toxicity, but which are not necessarily lethal. Under the new hazardous materials regulations, these materials are in Hazard Class Division 6.1, poisonous materials.

Liquids or gases that emit extremely toxic vapors even at normal temperatures. One example is methyl isocyanate, the material that was implicated in the deadly incident in Bhopal, India.
49 CFR Part 171.8; see also 49 CFR Parts 172 and 172.510 .

See also 49 CFR Part 173.115 .

See also 49 CFR Part 173.132.

See also 49 CFR Part 173.132. 
Portable tank

Precious metals

Preferred route or preferred highway

Preliminary

ascessment

Primary hazard

Principal place of business

Private track or private siding

\section{Production} reactor
A bulk packaging (except a cylinder having a water capacity of $1000 \mathrm{lb}$ or less) designed primarily to be loaded onto, or on, or temporarily attached to a transport vehicle or ship and equipped with skids, mountings, or accessories to facilitate handling of the tank by mechanical means. It does not include a cargo tank, tank car, multiunit tank-car tank, or trailer carrying $3 \mathrm{AS}, 3 \mathrm{AAX}$, or $3 \mathrm{~T}$ cylinders. It is usually used to transfer bulk materials from one type of transportation to another or for smaller quantities than tank car or tank truck shipments.

For the purposes of DOE series Orders, are defined as gallium, gold, iridium, osmium, palladium, platinum, rhodium, ruthenium, silver, or any combination of these metals.

Is a highway for shipment of "highway route controlled quantities" of radioactive materials so designated by a state routing agency, and any interstate highway system for which an alternative highway has not been designated by such state agency.

The process of collecting and reviewing available information about a known or suspected waste site or release.

The hazard class of a material.

A single location designated by the motor carrier, normally its headquarters, where required records are maintained.

Rail track located outside of a carrier's right-of-way, yard, or terminals where the carrier does not own the rails, ties, roadbed, or right-of-way, and includes track or portion of track which is devoted to the purpose of its user either by lease or written agreement, in which case the lease or written agreement is considered equivalent to ownership.

A reactor designed primarily for large-scale production of tritium or plutonium by neutron irradiation of U-238. The term also refers to a reactor used primarily for the production of isotopes.
49 CFR Part 171.8; see also 49 CFR Part 177.825.

49 CFR Part 171.8; see also 49 CFR Part 172.101 .

49 CFR Part 171.8 
Proper shipping

name

Protective

service

Proton

Public access

areas

Public vessel

Quality

Quality

assurance

Qualified driver

\section{Quality}

Assurance

Program

Radiation
The correct name of a hazardous material as listed in the Hazardous Materials Table.

Measures taken by commercial carriers upon written request to provide physical protection for shipments, which is in addition to the protection furnished under the requirements of normal common carrier activity.

A positively charged nuclear particle; one of the two principal components of nuclei. (See Neutron.)

Any areas not subject to controlled access.

A vessel owned by and being used in the public service of the United States. It does not include a vessel owned by the United States and engaged in a trade or commercial service or a vessel under contract or charter to the United States.

The degree to which an item or process meets or exceeds the user's requirements and expectations.

Actions that provide confidence that quality is achieved.

A driver who possesses a current drivers license; has an up-to-date, centrally maintained driver qualification file; maintains a drivers time record; and is physically qualified with a current medical examiner's certificate issued by a certified medical officer. In addition, except for intrastate drivers, drivers of commercial motor vehicles shall be enrolled in a drug-screening program.

A system of administrative and technical checks initiated to ensure that the requirements for an operations are well-defined and are met. The term includes other related terms such as quality control and compliance inspection.

The propagation of energy through matter or space in the form of waves, rays, or streams of energetic particles. The term is frequently used in relation to the emission of rays from the nucleus of an atom. In nuclear physics, the term has been extended to include fast-moving particles (e.g., alpha and beta particles) and gamma rays.
49 CFR Parts 171.8 and 172.101

49 CFR Part 171.8

See also IAEA Safety

Series 6.

See also IAEA Safety Series 6.

See also 40 CFR Part 190.02 and $10 \mathrm{CFR}$ Part 20.1003. 
Radiation level The radiation dose-equivalent rate expressed in millirem per hour (mrem/h). Neutron-flux densities may be converted into radiation levels according to the following table:

Neutron flux densities to be regarded as equivalent to a radiation level of $1 \mathrm{mrem} / \mathrm{h}$

\begin{tabular}{ll}
\hline Energy of neutron & $\begin{array}{l}\text { Flux density equivalent } \\
\text { to } 1 \text { mrem/h } \\
\text { [nNeutrons per square } \\
\text { centimeter per second } \\
\left.\left(\mathrm{n} / \mathrm{cm}^{2} / \mathrm{s}\right)\right]\end{array}$ \\
\hline
\end{tabular}

Thermal ......... 268.0

$5 \mathrm{keV} \ldots \ldots \ldots \ldots \ldots .228 .0$

$20 \mathrm{keV} \ldots \ldots \ldots \ldots \ldots 112.0$

$100 \mathrm{keV} \ldots \ldots \ldots \ldots \ldots 32.0$

$500 \mathrm{keV} \ldots \ldots \ldots \ldots \ldots 12.0$

$1 \mathrm{MeV} \ldots \ldots \ldots \ldots \ldots \ldots 7.2$

$5 \mathrm{MeV} \ldots \ldots \ldots \ldots \ldots .7 .2$

$10 \mathrm{MeV} \ldots \ldots \ldots \ldots \ldots .8$

Radioactive article

Radioactive contents

Radioactive decay

Radioactive material

Radioactive waste instrument, clock, electronic tube or apparatus, or similar instruments and articles having radioactive material as a component part.

The radioactive material, together with any contaminated liquids or gases, within the package.

The spontaneous decay or disintegration of an unstable atomic nucleus, accompanied by the emission of radiation.

Substances that emit radiation spontaneously. For purposes of transport, any material having a specific activity greater than $0.002 \mu \mathrm{Ci} / \mathrm{g}$.

A solid, liquid, or gaseous material of negligible economic value that contains radionuclides in excess
49 CFR Part 173.403; see also IAEA Safety Series 6.

49 CFR Part 173.403

Any manufactured instruments and articles such as an of threshold quantities. Does not include material contaminated by radionuclides from nuclear weapons testing.
49 CFR Part 173.403; see also 40 CFR Part 190.02, and IAEA Safety Series 6: 
Radioactivity

Radioisotope

Rail freight car

Receiver

Receptacle

Recognized chemical name

Recurrent training

Registered inspector

\section{Registered User}

The rate at which radioactive material is emitting radiation, given in terms of the number of nuclear disintegrations occurring in a unit of time. The common unit of radioactivity is the curie $(\mathrm{Ci})$, which is $3.7 \times 10^{10}$ disintegrations per second.

A radioactive isotope of a chemical element. (See Element, Isotope.)

A car designed to carry freight or nonpassenger personnel by rail, and includes a box car, flat car, gondola car, hopper car, tank car, and occupied caboose.

The receiver is the organization to which a shipment is being made. The shipper and receiver could be the same organization.

A containment vessel for receiving and holding materials, including any means of closing.

A name of a material used by qualified scientists or in scientific and technical literature.

See Retraining.

A person registered with DOT who has the knowledge and ability to determine if a cargo tank conforms with the applicable DOT specification and has, at a minimum, any of the following combinations of education and work experience in cargo-tank design, constructions, inspection, or repair:

1. an engineering degree and one year of work experience,

2. an associate degree in engineering and two years of work experience, or

3. a high school diploma (or general equivalency diploma and 3 years of work experience.

An NRC licensee who has registered with the NRC to use a specific packaging in accordance with the provisions of 10 CFR Part 71.12.
49 CFR Part 171.8

49 CFR Part 171.8; see also 49 CFR Part 107 Subpart F. 
Rem

Remedial action project

Remedial investigation

Remote-handled

Reportable quantity

Repository (federal)

Residue

Resource Conservation and Recovery Act
A measure of the dose of any ionizing radiation to body tissue in terms of its estimated biological effect relative to a dose of 1 roentgen ( $r$ ) of $x$-rays [ $1 \mathrm{mrem}=0.001 \mathrm{rem}]$. The relation of the rem to other dose units depends upon the biological effect under consideration and upon the conditions for irradiation.

A group of activities initiated to assess a DOE facility or radioactive waste site that may require restoration to achieve acceptable radiation levels.

The Comprehensive Environmental Response, Compensation, and Liability Act process of determining the extent of hazardous substance contamination, and, as appropriate, conducting treatability investigations. The in-depth study is designed to gather the data necessary to determine the nature and extent of contamination at a Comprehensive Environmental Response, Compensation, and Liability Act site; establish criteria for cleaning up the site; identity preliminary alternatives for remedial action; and support the technical and cost analyses of the alternatives. The remedial investigation is usually effected along with the feasibility study. Together, they are usually referred to as the "RI/FS."

Radioactive containers with a level of radioactivity sufficiently high to require shielding and handling remotely.

Hazardous substances, when shipped in certain quantities per package.

See also 49 CFR Parts 171.8 and 172.101 .

A federally owned and operated engineered facility for storage or disposal of specific types of radioactive waste for which the Department of Energy is responsible.

The material remaining in or clinging to the inside of a container after it is unloaded, but not cleaned or purged.

An amendment to the Solid Waste Disposal Act, which was passed in 1976 to address the problem of how to safely dispose of municipal and industrial solid waste generated nationwide. It established a
See also 49 CFR Part 171.8. 
national policy to reduce or eliminate hazardous waste and conduct treatment, storage, or disposal to minimize any threat from the waste. The Resource Conservation and Recovery Act was amended by the Hazardous and Solid Waste Amendments in 1984 to expand the scope of and to add detailed requirements to the Act.

Retraining

Retrievability

Reusable packaging

Risk ascessment

Root cause

Safe Drinking Water Act

Safe-secure railcar

Safe-secure trailer
The training required to be given at least once every 2 years to hazardous material employees who have previously received training.

Capability to remove waste from its place in storage.

Containers, such as tank cars or cylinders, used repeatedly to transport hazardous materials.

The qualitative and quantitative evaluation performed in an effort to define the risk posed to human health and/or the environment by the presence or potential presence and/or the use of specific pollutants.

Those causal factors that, if corrected, would preclude a recurrence of the event.

Protects drinking water supplies. The maximum contaminant levels developed under this Act are used in groundwater monitoring programs.

A specially designed railcar that has protective and deterrent systems and is used in a special train to transport nuclear explosives or special nuclear material.

A specially designed semitrailer that has protective and deterrent systems that is used with a special tractor to transport nuclear explosives or special nuclear material. 
Safety Analysis

Report for

Packaging

Safety training

Sanitary waste

\section{Seven or eight consecutive-day period}

Shallow land burial

Sheathing

Shielding

Shipment

Shipper
A document that provides a comprehensive technical basis for demonstrating how a packaging meets the regulatory requirements. It contains the design, testing, operational procedures, maintenance procedures, and quality assurance program for packaging to demonstrate compliance with the NRC regulatory safety standards, or equivalent standards established by DOE for approving packagings and issuing certificates of compliance.

Instruction concerning emergency response information and accident avoidance.

Waste, such as garbage, that is generated by normal housekeeping activities and is not hazardous or radioactive. This waste is disposed of in sanitary landfills. Sanitary waste also includes liquids which are treated in sewage treatment plants.

The period of seven or eight consecutive days beginning on any day at midnight. Each day is a period of 24 consecutive hours beginning at midnight. Used in determining commercial drivers' eligibility to continue work.

Disposal of waste in shallow trenches; commonly used for low-level radioactive waste.

A covering consisting of a smooth layer of wood placed over metal and secured to prevent any movement.

Materials such as concrete, water, and lead, that are used to attenuate the transmission of ionizing radiation.

Any offsite transport of hazardous materials. It involves activities such as package loading, marking, and labeling; cargo securement; placarding; preparation of shipping documents; and tendering the package to the carrier or transporter.

The organization and/or person who offers a shipment to a carrier for transportation.
See also IAEA Safety Series 6. 
Shipper's

Declaration for

Dangerous

Goods

Shipping name

Shipping order

Shipping paper

Sievert

Siftproof

packaging

Single packaging

Single-trip

container

Site

Site inspection

Sludge
A shipping paper (with a red border) used for air shipments of hazardous materials.

See Proper shipping name.

See Shipping paper.

A shipping order, bill of lading, hazardous waste manifest or other shipping document serving a similar purpose and containing the information required by the regulations.

The International System unit of dose equivalent, which relates dose to biological effects by using the quality factor, $\mathbf{Q}$.

A packaging impermeable to dry contents, including fine solid material produced during transportation.

A nonbulk packaging other than a combination packaging.

A container not allowed to be used for transportation more than once, unless properly reconditioned. (See Nonreusable container.)

An area of land that contains a DOE facility or facilities, which is either owned or leased by the DOE or the federal government. The land may be divided by public rights-of-way. Lands, installations, and/or facilities for which DOE has or shares responsibility for environmental restoration and waste management activities.

The collection of information from a CERCLA (Superfund) site to determine the extent and severity of hazards posed by the site. It follows a preliminary assessment and is more extensive. The purpose is to gather information necessary to score the site, using the U.S. Environmental Protection Agency Hazard Ranking System, and to determine if the site presents an immediate threat that requires prompt removal action. (See National Priorities List)

Slushy matter or sediment such as that precipitated by the treatment of liquid or solid waste.
49 CFR Part 171.8; see also 49 CFR Parts 172.202, 203, and 204.

49 CFR Part 171.8

See also 40 CFR Part 191.02. 

or less within a $3-\mathrm{m}$ period, or a separation of $1 \mathrm{~g}$ or less of liquid when determined in accordance with the procedures specified in ASTM D 4359-84, "Standard Test Method for Determining Whether a Material is a Liquid or Solid," 1984.

Solid waste

Solution

Source material

Special approval

Special arrangement

Special form radioactive material
Nonliquid, nonsoluble material ranging from municipal garbage to industrial waste that contains complex, and sometimes hazardous, substances. Solid waste also includes sewage sludge, agricultural refuse, demolition wastes, and residues. Technically, solid waste also refers to liquids and gases in containers.

Any homogeneous liquid mixture of two or more chemical compounds or elements that will not undergo any segregation under conditions normal to transportation.

Uranium or thorium, or any combination thereof, in any physical or chemical form; or ores which contain by weight one-twentieth of one percent $(0.05 \%)$ or more of (a) uranium, (b) thorium or (c) any combination thereof. Source material does not include special nuclear material.

A DOT approval for a specified type of container or shipment.

Those provisions, approved by the competent authority, under which a consignment which does not satisfy all the applicable requirements of the regulations may be transported. For international shipments, multilateral approval is required.

Radioactive material which satisfies the following conditions:

1. It is either a single solid piece or is contained in a sealed capsule that can be opened only by destroying the capsule;

2. the piece or capsule has at least one dimension not less than $5 \mathrm{~mm}(0.197 \mathrm{in.}$ ); and

3. it satisfies the test requirements of DOT.
See also 40 CFR Parts 240.101 and 261.2.

49 CFR Part 171.8

10 CFR Part 20.1003

IAEA Safety Series 6

49 CFR Part 173.403 and 10 CFR Part 71.4; see also IAEA Safety Series 6. 
Special nuclear material

Specific activity

\author{
Specification \\ marks \\ Specification \\ number \\ Specification \\ packaging
}

Spent nuclear fuel

Stabilization

Standard cubic foot

Standardized leakage rate
Plutonium, U-233, uranium enriched in U-233 or U-235, and any other material which NRC, determines to be special nuclear material, but does not include source material; or any material artificially enriched by any of the foregoing but does not include source material.

The activity of the radionuclide per unit mass of that nuclide. The specific activity of a material in which the radionuclide is essentially uniformly distributed is the activity per unit mass of the material.

See DOT specification marks.

See DOT specification number.

A packaging conforming to one of the specifications or standards for packagings.

Nuclear reactor fuel that has been irradiated to the extent that it can no longer effectively sustain a chain reaction. Fuel becomes spent when its fissionable isotopes have been partially consumed and fissionproduct poisons have accumulated in it.

Conversion of the active organic matter in sludge into inert, harmless material. Also, activities to reduce the active management required for disposal facilities (such as burial ground stabilization and closure).

One cubic foot of gas measured at $60^{\circ} \mathrm{F}$ and 14.7 psia.

The leakage rate, evaluated under known conditions, normalized to the flow of dry air at reference conditions from an upstream pressure $1.013 \times 10^{5} \mathrm{~Pa}$ to a downstream pressure of $0 \mathrm{~Pa}$ at a temperature of $298 \mathrm{~K}\left(25^{\circ} \mathrm{C}\right)$. The units for standardized leakage rate are written as $\mathrm{Pa} \mathrm{m}^{3} \mathrm{~s}^{-1}$ SIR.
49 CFR Part 173.403; see also 10 CFR Part 71.4 and IAEA Safety Series 6.
49 CFR Part 171.8; see also 49 CFR Parts 178 and 179.

10 CFR Part 2.1105 
Standardized helium leakage rate

State

State-designated route

State routing agency

Stowage

Strong outside container

\section{Strong tight} package

Subsidiary hazard
The helium flow rate through a leak at an upstream pressure $\underline{P}_{u}$ of $1.013 \times 10^{5} \mathrm{~Pa} \pm 5 \times 10^{3} \mathrm{~Pa}$ and a downstream pressure $P_{d}$ of $10^{3} \mathrm{~Pa}$ or less at a temperature of $296 \mathrm{~K} \pm 7 \mathrm{~K}\left(23^{\circ} \mathrm{C} \pm 7^{\circ} \mathrm{C}\right)$. The units for the standardized helium leakage rate are written as $\mathrm{Pa} \cdot \mathrm{m}^{3} \mathrm{~s}^{-1}$ SHeLR.

A state of the United States, the District of Columbia, the Commonwealth of Puerto Rico, the Commonwealth of the Northern Mariana Islands, the Virgin Islands, American Samoa, Guam, or any other territory or possession of the United States designated by the Secretary of Transportation.

A preferred route selected in accordance with DOT "Guidelines for Selecting Preferred Highway Routes for Highway Route Controlled Quantities of Radioactive Materials" or an equivalent routing analysis which adequately considers overall risk to the public.

An entity (including a common agency of more than one state such as one established by Interstate compact) which is authorized to use state legal process to impose routing requirements, enforceable by state agencies, on carriers of radioactive materials without regard to intrastate jurisdictional boundaries. This term includes also Indian tribal authorities who have police powers to regulate and enforce highway routing requirements within their lands.

The act of placing hazardous materials on board a vessel.

The outermost enclosure which provides protection from the unintentional release of its contents under conditions normally incident to transportation.

A package that will not leak any type of materials during conditions normally incident to transportation.

A hazard or a material other than the primary hazard.
49 CFR Part 171.8; see also 10 CFR 71.4 .

49 CFR Part 171.8

49 CFR Part 171.8

49 CFR Part 171.8

49 CFR Part 171.8

49 CFR Parts 173.24 and 173.421

49 CFR Part 171.8 


\author{
Superfund \\ Amendments \\ and \\ Reauthorization \\ Act
}

Supervisor

Supplier

Surfacecontaminated object
The 1986 Act reauthorizing and amending the Comprehensive Environmental Response, Compensation, and Liability Act.

An individual who is a properly trained and knowledgeable hazardous materials employee and, therefore, is allowed to supervise hazardous materials employees.

The supplier is an organization that provides equipment and services for the shipment of materials.

A solid object which is not itself radioactive but which has radioactive material distributed on its surfaces. Surface-contaminated objects (SCO) shall be in one of two groups:

1. SCO-I: A solid object on which:

- the non-fixed contamination on the accessible surface averaged over $300 \mathrm{~cm}^{2}$ (or the area of the surface if less than $300 \mathrm{~cm}^{2}$ ) does not exceed $4 \mathrm{~Bq} / \mathrm{cm}^{2}\left(10^{-4} \mu \mathrm{Ci} / \mathrm{cm}^{2}\right)$ for beta and gamma emitters, or $0.4 \mathrm{~Bq} / \mathrm{cm}^{2}\left(10^{-5} \mu \mathrm{Ci} / \mathrm{cm}^{2}\right)$ for alpha emitters; and

- the fixed contamination on the accessible surface averaged over $300 \mathrm{~cm}^{2}$ (or the area of the surface if less than $300 \mathrm{~cm}^{2}$ ) does not exceed $4 \times 10^{4} \mathrm{~Bq} / \mathrm{cm}^{2}\left(1 \mu \mathrm{i} / \mathrm{cm}^{2}\right)$ for beta and alpha emitters; and

- the nonfixed contamination plus the fixed contamination on the inaccessible surface averaged over $300 \mathrm{~cm}^{2}$ (or the area of the surface if less than $300 \mathrm{~cm}^{2}$ ) does not exceed $4 \times 10^{2} \mathrm{~Bq} / \mathrm{cm}^{2}\left(1 \mu \mathrm{i} / \mathrm{cm}^{2}\right)$ for beta and gamma emitters, or $4 \times 10^{3} \mathrm{~Bq} / \mathrm{cm}^{2}$ $\left(0.1 \mu \mathrm{i} / \mathrm{cm}^{2}\right)$ for all other alpha emitters.

2. SCO-II: A solid object on which either the fixed or nonfixed contamination on the surface exceeds the applicable limits specified for SCO-I in (1.) above and on which:

- the nonfixed contamination of the accessible surface averaged over $300 \mathrm{~cm}^{2}$ (or the area of the surface if less than $300 \mathrm{~cm}^{2}$ ) does not
IAEA Safety Series 6 
Surplus facility

Tamperindicating devices

Tank

Tank truck

Technical name exceed $400 \mathrm{~Bq} / \mathrm{cm}^{2}\left(10^{-2} \mu \mathrm{Ci} / \mathrm{cm}^{2}\right)$ for beta and gamma emitters, or $40 \mathrm{~Bq} / \mathrm{cm}^{2}$ $\left(10^{-3} \mu \mathrm{Ci} / \mathrm{cm}^{2}\right)$ for all other alpha emitters; and

- the fixed contamination on the accessible surface averaged over $300 \mathrm{~cm}^{2}$ (or the area of the surface if less than $300 \mathrm{~cm}^{2}$ ) does not exceed $8 \times 10^{5} \mathrm{~Bq} / \mathrm{cm}^{2}\left(20 \mu \mathrm{Ci} / \mathrm{cm}^{2}\right)$ for beta and gamma emitters, or $8 \times 10^{4} \mathrm{~Bq} / \mathrm{cm}^{2}$ $\left(2 \mu \mathrm{Ci} / \mathrm{cm}^{2}\right)$ and all other alpha emitters; and

- the nonfixed contamination plus the fixed contamination on the inaccessible surface averaged over $300 \mathrm{~cm}^{2}$ (or the area of the surface if less than $\left.300 \mathrm{~cm}^{2}\right)$ does not exceed $8 \times 10^{5} \mathrm{~Bq} / \mathrm{cm}^{2}\left(20 \mu \mathrm{Ci} / \mathrm{cm}^{2}\right)$ for beta and gamma emitters, or $8 \times 10^{4} \mathrm{~Bq} / \mathrm{cm}^{2}$ $\left(2 \mu \mathrm{Ci} / \mathrm{cm}^{2}\right)$ for all other alpha emitters.

Any facility or site (including equipment) that has no identified programmatic use and may or may not be contaminated.

Devices that may be used on containers and that, because of their uniqueness in design or structure, reveal violations of containment integrity. Tamperindicating devices include seals, mechanisms, containers, and enclosures.

A tank container, portable tank, a road tank vehicle, a rail tank wagon or a receptacle with a capacity of not less than $450 \mathrm{~L}$ intended to contain liquids, powders, granules or slurries and of not less than 1000 liters intended to contain gases. A tank container shall be capable of being carried on land or on sea and of being loaded and discharged without the need of removal of its structural equipment, shall possess stabilizing members and tie-down attachments external to the shell, and shall be capable of being lifted when full.

A truck used to carry bulk materials. See also Cargo tank

A recognized chemical name or microbiological name currently used in scientific and technical handbooks, journals, and texts. Generic descriptions are authorized for use as technical names provided that they readily identify the general chemical or
IAEA Safety Series 6

49 CFR Part 171.8 
microbiological group. Examples of acceptable generic chemical descriptions are organic phosphate compounds, petroleum aliphatic hydrocarbons, and tertiary amines. For proficiency testing only, generic microbiological descriptions such as bacteria, mycobacteria, fungi, and viral samples may be used.

Testing

Tiedown

Tiedown attachment points

Tiedown owner

Top shell

Toxic Substances Control Act

Trade name

Traffic management
Oral and/or written tests given to each hazardous material employee to determine whether the training received by such employee is effective.

A system for securing packages containing hazardous or radioactive materials to vehicles (including straps, cables, chains, bolts, attachment devices, tightening devices, etc.).

The location where the tiedown attaches to the structure of the semitrailer.

The individual, agency, contractor, company, or corporation that holds title to or will hold title to the tiedown during its use.

The tank-car tank surface, excluding the head ends and bottom shell of the tank-car tank.

Enacted in 1976 to protect human health and the environment from unreasonable risk from exposure to and manufacture, distribution, use, or disposal of substances containing toxic chemicals. For example, any hazardous waste that contains more than 50 parts per million (ppm) of polychlorinated biphenyls (PVC) are subject to regulations under this Act.

A commercial name assigned to a product for sales, marketing, or similar purposes or used for a company's internal designation of a product.

All functional activities related to the planning, direction, selection, purchase, and use of transportation services efficiently, effectively, and economically while ensuring full compliance with applicable international, federal, state, tribal, and local regulations, DOE policy, and good business management practices. 

cars, except during switching operations or where the operation is that of classifying and assembling rail cars within a railroad yard for the purpose of making or breaking up trains.

Training record

Trainship

Transfer

Transferee

Transferor

Transport index

Transport vehicle
A written record of the training and testing given to each hazardous materials employee.

A vessel other than a rail-car ferry or carfloat, specifically equipped to transport railroad vehicles, and fitted with installed securing devices to tie down each vehicle.

Any onsite transport of hazardous materials, other than intrabuilding movements. It involves activities such as packaging, loading, marking and labeling, cargo security, placarding, and preparation of shipping documents as appropriate in addition to the transportation of the material via any transport vehicle.

(1) a person to whom a conveyance is made. (2) one who is transferred.

One that conveys a title, right or property.

The dimensionless number (rounded up to the first decimal place) placed on the label of a package to designate the degree of control to be exercised by the carrier during transportation. The transport index is determined as follows:

1. the number expressing the maximum radiation level in millirem per hour at $1 \mathrm{~m}(3.3 \mathrm{ft})$ from the external surface of the package, or

2. for Fissile Class II packages or packages in a Fissile Class III shipment, the number expressing the maximum radiation level at $1 \mathrm{~m}$ ( $3.3 \mathrm{ft}$ ) for the external surface of the package, or the number obtained by dividing 50 by the allowable number of packages which may be transported together, whichever is larger.

Any conveyance (motorized or towed, railcar, aircraft, boat, barge, or seagoing vessel) used for the transfer or transportation of property.
10 CFR 71.4;

see also 49 CFR Part 173.403 and IAEA Safety Series 6.
See also 49 CFR Part 171.8. 
Transportation

Transportation Emergency Preparedness Program

Transportation safety manual

Transuranic elements

Transuranic waste

Test gas or tracer gas

Treatment

Tumulus
The offsite shipment of cargo from one point to another using a transport vehicle.

An emergency preparedness program in the DOE which concentrates on shipments and DOE capabilities to carry out responsibilities under the National Contingency Plan, Federal Radiological Emergency Response Plan, and other regulations.

A document which contains, explicitly or by reference, procedures or guidance implementing the DOE policy for onsite transfers of hazardous materials. The transportation safety manual may also include reference to documentation that implements the DOE policy for offsite transportation.

Elements heavier than uranium, with an atomic number greater than 92 . They include, among others, neptunium, plutonium, americium, and curium.

Waste that is contaminated with alpha-emitting transuranium nuclides with half-lives greater than 20 years and concentrations greater than 100 nanocuries per gram of waste. Contact-handled transuranic waste does not require shielding and has a surface dose rate of less than $200 \mathrm{mrem} / \mathrm{h}$.

Remote-handled transuranic waste has a surface dose rate greater than $200 \mathrm{mrem} / \mathrm{h}$ and requires additional shielding because it presents an exposure hazard. The dose rates at the surface of remote-handled transuranic waste packages fall within the 200 to $1,000 \mathrm{rem} / \mathrm{h}$ range.

The gas that is used to detect leakage or measure leakage rates.

Any activity that alters the chemical or physical nature of radioactive or hazardous waste to reduce toxicity, volume, mobility, or render it amenable for transport, storage, or disposal.

Above-ground waste burial using materials including cement, plastics, and dirt. Radioactive waste is immobilized, stored in concrete vaults, placed on an above-ground concrete storage pad, and covered with plastic and dirt. In humid or wet regions, tumulus disposal protects the water table.
See also 40 CFR Part 191.02. 
Type A package

Type A packaging

Type AF packaging

Type A quantity

Type B package

Type B packaging

Type B(M) package

Type B(U) package

Type B quantity
A Type A packaging together with limited radioactive contents. A Type A package does not require competent authority approval because its contents are limited to $A_{1}$ or $A_{2}$ quantities.

A packaging designed to retain the integrity of containment and shielding required under normal conditions of transport.

A Type A packaging designed for fissile materials.

A quantity of radioactive material not exceeding the $A_{1}$ or $A_{2}$ value for the specified radionuclide.

A Type B packaging together with its radioactive contents.

A packaging designed to maintain containment, subcriticality, and shielding under normal conditions of transport and hypothetical accident test conditions.

A Type B packaging, together with its radioactive contents, that for international shipments requires multilateral approval of the package design, and may require approval of the conditions of shipment. Type $B(M)$ packages are those Type B package designs which have a maximum normal operating pressure of more than $7 \mathrm{~kg} / \mathrm{cm}^{2}$ (100 lb per sq in.) gauge or a relief device which would allow the release of radioactive material to the environment under the hypothetical accident conditions specified in 10 CFR Part 71.

A Type B packaging, together with its radioactive contents, that for international shipments, requires unilateral approval only of the package design and of any stowage provisions that may be necessary for heat dissipation.

A quantity of radioactive material exceeding the $A_{1}$ or $A_{2}$ values, as applicable, for the specific radionuclide.
49 CFR Part 173.403; see also LAEA Safety Series 6.

49 CFR Part 173.403; see also 49 CFR Parts 173.465 and 466.

See also 10 CFR Part 71.4.

49 CFR Part 173.403; see also 10 CFR Part 71.4 and IAEA Safety Series 6.

also see 49 CFR Part 173.403

49 CFR Part 173.403; see also 10 CFR Part 71 and IAEA Safety Series 6.

49 CFR Part 173.403; see also IAEA Safety Series 6.

See also 10 CFR 71.4. 
UN specification marks

UN standard packaging

Uncompressed gas

Underground storage tank

Unilateral approval

Unirradiated thorium

Unirradiated uranium

Unit load device

United States

Unqualified

driver

Uranium
Marks which the Department of Transportation requires to be placed on UN-type packages (used under the new hazardous materials rules), showing the UN identification number and related information.

A specification packaging conforming to the requirements in the regulations.

Gas at a pressure not exceeding the ambient atmospheric pressure at the time and location the containment system is closed. All other radioactive gases are considered to be compressed.

Any tank or associated piping containing hazardous materials as defined by the Hazardous and Solid Waste Amendments Act (Subtitle C or Subtitle I).

Approval by the competent authority of the country of origin only.

Thorium containing not more than $10^{-7} \mathrm{~g} \mathrm{U}-233$ per $1 \mathrm{~g}$ of Th-232.

Uranium containing not more than $10^{-6} \mathrm{~g}$ plutonium per $1 \mathrm{~g}$ of U-235 and a fission product activity of not more than $0.25 \mathrm{mCi}$ of fission products per gram of U-235.

Any type of freight container, aircraft container, aircraft pallet with a net, or aircraft pallet with a net over an igloo.

See State.

A driver not meeting one or more of DOT requirements.

A naturally occurring radioactive heavy-metal element with the atomic number of 92 and an atomic weight of approximately 238 . The two principal isotopes are the fissionable U-235 $(0.7 \%$ of natural uranium) and the U-238 ( $99.3 \%$ of natural uranium).
49 CFR Part 171.8; see also 49 CFR Part 178 Subparts $L$ and $M$ or $\mathrm{N}$ and $\mathrm{O}$.

49 CFR Part 173.403; see also IAEA Safety Series 6.

49 CFR Part 173.403; see also IAEA Safety Series 6.

49 CFR Part 173.403; see also IAEA Safety Series 6.

49 CFR Part 173.403; see also IAEA Safety Series 6.
See also 10 CFR 71.4 and IAEA Safety Series 6. 
Uranium mill tailings

Uranium Mill

Tailings

Radiation

Control Act of 1978

Vehicle

Vehicle custodian

Vessel

Viscous flow

Viscous liquid

Vitrification

Vitrify

Volatility
Naturally occurring radioactive rock and soil that are the result of uranium mining and milling. Tailings may contain other minerals or metals not extracted in the process of mining uranium for ore.

This Act directed the DOE to provide for stabilization and control of the uranium mill tailings from inactive sites in a safe and an environmentally sound manner to minimize radiation health hazards to the public. It authorizes DOE to undertake remedial actions at 24 designated inactive uranium processing sites and at an estimated 5,048 vicinity properties. The Uranium Mill Tailings Remedial Action Project accomplishes this cleanup.

See Transport vehicle.

A person organizationally responsible for vehicles in his or her custody.

Includes every description of water craft used or capable of being used as a means of transportation on the water.

The flow of gas through a leak under conditions such that the mean free path is very small in comparison with the smallest dimension of a transverse section of the leak. This flow may be either laminar or turbulent.

A liquid material which has a measured viscosity in excess of 2500 centistokes at $25^{\circ} \mathrm{C}\left(77^{\circ} \mathrm{F}\right)$ when determined in accordance with the procedures specified in ASTM Method D 445-72, "Kinematic Viscosity of Transparent and Opaque Liquids (and the Calculation of Dynamic Viscosity)," or ASTM Method D 1200-70, "Viscosity of Paints, Varnishes, and Lacquers by Ford Viscosity Cup."

The process of immobilizing waste that produces a glass-like solid that permanently captures the radioactive materials.

To form into a glass-like material by heating, melting, and cooling.

The relative rate of evaporation of materials to assume the vapor state.
See also 40 CFR Part 192.31.

IAEA Safety Series 6

49 CFR Part 171.8; see also IAEA Safety Series 6.

49 CFR Part 171.8 
Waste immobilization

Waste Isolation Pilot Plant

Waste manifest

Waste minimization

Waste stream

Water reactive

Water resistant

Waybill
The process of converting waste to a stable, solid form that encases the radionuclides to prevent or slow their migration to the biosphere.

Research and demonstration facility of the Department of Energy located at Carlsbad, New Mexico, intended to demonstrate safe disposal of radioactive waste in a deep geologic (salt) environment. A decision on whether to convert the Waste Isolation Pilot Plant to a disposal facility for transuranic waste will be made after successful testing is demonstrated.

\section{See Shipping paper.}

The reduction, to the extent feasible, of radioactive and hazardous waste that is generated before treatment, storage, or disposal of the waste. Waste minimization includes any source reduction or recycling activity that results in either (1) reduction of total volume of hazardous waste; (2) reduction of toxicity of hazardous waste; or (3) both.

Term used to refer to waste leaving a facility or operation.

A chemical that reacts with water to release a gas that is either flammable or presents a health hazard.

29 CFR

Part 1910.1200

Having a degree of resistance to permeability by and damage caused by water in liquid form.

49 CFR Part 171.8

See Shipping paper. 


\section{REFERENCES}

\subsection{FEDERAL REGULATIONS}

\subsubsection{U.S. Nuclear Regulatory Commission}

10 CFR Part 71, "Packaging and Transportation of Radioactive Material."

10 CFR Part 73, "Physical Protection of Plants and Materials."

10 CFR Part 110, "Export and Import of Nuclear Equipment and Material."

\subsubsection{U.S. Department of Energy}

10 CFR Part 871, "Air Transportation of Plutonium."

10 CFR Part 961, "Standard Contract for Disposal of Spent Nuclear Fuel and/or High-Level Radioactive Waste."

\subsubsection{U.S. Department of Commerce}

15 CFR Parts 700-799, "Export Administration Regulations."

\subsubsection{U.S. Department of the Treasury, U.S. Customs Service}

19 CFR Part 161.2, "Enforcement for Other Agencies" (concerning import/export of nuclear materials). 


\subsubsection{U.S. Department of Labor}

29 CFR Part 1905, "Rules of Practice for Variances, Limitations, Variations, Tolerances, and Exemptions under the Williams-Steiger Occupational Safety and Health Act of 1970."

29 CFR Part 1910, "Occupational Safety and Health Standards."

29 CFR Part 1915, "Occupational Safety and Health Standards for Shipyard Employment."

29 CFR Part 1918, "Safety and Health Regulations for Longshoring."

29 CFR Part 1926, "Safety and Health Regulations for Construction."

29 CFR Part 1928, "Occupational Safety and Health Standards for Agriculture."

29 CFR Part 1960, "Basic Program Elements for Federal Employee Occupational Safety and Health Programs and Related Matters."

\subsubsection{U.S. Environmental Protection Agency}

40 CFR Parts 260-281, "Environmental Protection Agency Regulations."

\subsubsection{General Services Administration}

41 CFR Part 101, "Federal Property Management Regulations."

41 CFR, Chapter 109, "Department of Energy Property Management Regulations," Parts 109-40, "Transportation and Traffic Management." 
41 CFR Chapter 201, Parts 201-1-201-99, "Federal Information Resources Management Regulations."

48 CFR Chapter 1, Parts 1-99, 942.14, and 947, "Federal Acquisition Regulations System."

48 CFR Part 47, "Transportation."

48 CFR Parts 900-999, "Department of Energy Federal Acquisition Regulations System."

4.1.8 U.S. Department of Health and Human Services

42 CFR Part 72, "Interstate Shipment of Etiologic Agents."

\subsubsection{U.S. Department of Transportation}

14 CFR Part 1, "Definitions and Abbreviations."

14 CFR Part 61, "Certification: Pilots and Flight Instructors."

14 CFR Part 77, "Objects Affecting Navigable Airspace."

14 CFR Part 91, "General Operating and Flight Rules."

14 CFR Part 121, "Certification and Operations: Domestic, Flag, and Supplemental Air Carriers and Commercial Operators of Large Aircraft."

14 CFR Part 125, "Certification and Operations: Airplanes Having a Seating Capacity of 20 or More Passengers or a Maximum Payload Capacity of 6,000 Pounds or More."

14 CFR Part 135, "Air Taxi Operators and Commercial Operators." 
49 CFR Part 40, "Procedures for Transportation Workplace Drug Testing Program."

49 CFR Parts 107-180, "Hazardous Materials Regulations."

49 CFR Parts 211-240, "Federal Railroad Administration."

49 CFR Parts 350-399, "Federal Motor Carrier Safety Regulations."

49 CFR Part 830, "Rules Pertaining to the Notification and Reporting of Aircraft Accidents or Incidents and Overdue Aircraft, and Preservation of Aircraft Wreckage, Mail, Cargo, and Records."

49 CFR Parts 1035, 1043, 1051, 1150-1174, and 1312, "Interstate Commerce Commission Regulations."

\subsubsection{U.S. Postal Service}

Acceptance of Hazardous, Restricted, or Perishable Articles, Publication 52, U.S. Postal Service, Sommerville, New Jersey, 1994.

\subsection{FEDERAL LAWS}

Cargo Preference Act (Merchant Marine) of 1954, Pub. L. 664, Chap. 936, 68 Stat. 832, August 26, 1954: 46 U.S.C. Sect. 1241, 1982; 49 U.S.C., Sect. 1517, 1988.

Federal Property and Administrative Services Act of 1949, Pub. L. 81-152, 63 Stat. 377, June 30, 1949.

Hazardous Materials Transportation Act of 1974, Pub. L. 93-633, 49 U.S.C. Sect. 1801 et seq., 88 Stat. 2156, January 3, 1975. 
Hazardous Materials Transportation Uniform Safety Act of 1990, Pub. L. 101-615, 104 Stat. 3244, November 16, 1990.

Interstate Commerce Act, Part 4, Pub. L. 77-558, Chap. 318, 56 Stat. 284, May 16, 1942; 49 U.S.C., Subtitle IV, Chap. 107, 1988.

Nuclear Non-Proliferation Act of 1978, Pub. L. 94-242, March 10, 1978.

Occupational Safety and Health Act of 1970, Publ. L. 91-596, 29 U.S.C. 651 et seq., 84 Stat. 1590, December 29, 1970.

\section{INTERNATIONAL REGULATIONS}

IATA Restricted Articles Regulations, International Air Transport Association, Montreal, Quebec, Canada, 1944, (issued yearly).

International Atomic Energy Agency, Safety Series No. 6 LAEA Safety Standards, Regulations for the Safe Transport of Radioactive Material 1985 Edition (as amended 1990), Vienna, Austria, 1990.

International Maritime Organization, International Maritime Dangerous Goods Code, 1990 Consolidated Edition, London, England, 1991.

\subsection{DOE ORDERS}

The following DOE Orders have direct applicability to the packaging and transportation operations and safety of DOE facilities. A complete listing of all DOE Orders is presented in Appendix A. 
Order

Subject

Change Date

1324.2A Records Disposition

$04 / 09 / 92$

1540.1A Materials Transportation and Traffic

$07 / 08 / 92$

Management

1540.2 Hazardous Material Packaging for Transport-

$12 / 19 / 88$

Administrative Procedures

1540.3A Base Technology for Radioactive Material Transportation

$07 / 08 / 92$

Packaging Systems

4330.4B Maintenance Management Program

$02 / 10 / 94$

5000.3B Occurrence Reporting and Processing of Operations

$01 / 19 / 93$

Information

5480.1B ES\&H Program for DOE Operations

$05 / 10 / 93$

5480.3 Safety Requirements for the Packaging and

07/09/85

Transportation of Hazardous Materials, Hazardous

Substances, and Hazardous Wastes

5480.4 Environmental Protection, Safety, and Health Protection

$01 / 07 / 93$

Standards

$5480.5 \quad$ Safety of Nuclear Facilities

$09 / 23 / 86$

5480.7A Fire Protection

$02 / 17 / 93$

5480.8A Contractor Occupational Medical Program

$10 / 19 / 92$ 
5480.10 Contractor Industrial Hygiene Program

5480.11 Radiation Protection for Occupational Workers

$06 / 17 / 92$

5480.13A Aviation Safety

$02 / 23 / 93$

5480.18A Accreditation of Performance-Based Training for Category A

$07 / 19 / 91$

Reactors and Nuclear Facilities

5480.19 Conduct of Operations Requirements for DOE Facilities

$05 / 18 / 92$

5480.20

Personnel Selection, Qualification, Training, and Staffing

$06 / 19 / 91$

Requirements at DOE Reactor and Non-Reactor Nuclear

Facilities

5482.1B Environment, Safety and Health Appraisal Program

$11 / 18 / 91$

5483.1A Occupational Safety and Health Program for DOE Contractor

$06 / 22 / 83$ Employees at Government-Owned Contractor-Operated Facilities

5500.1B Emergency Management System

$02 / 27 / 92$

5500.3A Planning and Preparedness for Operational Emergencies

$02 / 27 / 92$

5632.11 Physical Protection of Unclassified, Irradiated Reactor

03/04/94

Fuel in Transit

5700.6C Quality Assurance

$08 / 21 / 91$

5820.2A Radioactive Waste Management

09/26/88 


\subsection{OTHER DOCUMENTS}

American Trucking Associations, ATA Hazardous Materials Tariff, No. 111M, American Trucking Associates, Alexandria, Virginia, 1994.

American Trucking Associations, National Motor Freight Classification, NMFC-100U, American Trucking Associations, Alexandria, Virginia, 1994.

ANSI N14.1-1990, "Uranium Hexaflouride-Packaging for Transport," 1990.

ANSI N14.5-1987, "Leakage Tests on Packages for Shipment," 1987.

ANSI N14.6-1993, "Special Lifting Devices for Shipping Containers Weighing 10,000 Pounds $(4500 \mathrm{~kg})$ or More," 1993.

ANSI N14.19-1986, "Irradiated Fuel Shipping Casks-Ancillary Features," 1986.

ANSI N14.24-1985, "For Highway Route Controlled Quantities of Radioactive Materials-Domestic Barge Transport," 1985.

ANSI N14.27-1986, "For Truckload Quantities of Radioactive Materials-Carrier and Shipper Responsibilities and Emergency Response Procedures for Highway Transportation Accidents," 1987.

ANSI N14.29-1988, "Guide for Writing Operating Manuals for Packaging," 1989.

ANSI N14.30-1992, "Semi-Trailers Employed in the Highway Transport of Weight-Concentrated Radioactive Loads - Design, Fabrication, and Maintenance," 1993.

J. M. Cruse, Test and Evaluation Document for DOT Specification 7A Type A Packaging, WHC-EP-0558, Rev 1, Westinghouse Hanford Company, Richland, Washington, January 1994. 
L. M. Houlberg, G. T. Hawkins, R. E. Bock, and M. S. Salk, Environmental Regulatory Update Table, ORNL/M-3271/R2, Martin Marietta Energy Systems, Oak Ridge National Laboratory, May-June 1994.

International Civil Aviation Organization, Technical Instructions for the Safe Transport of Dangerous Materials by Air, Doc 9284-AN/905, 1993-1994 edition, Montreal, Quebec, Canada, 1992.

National Railroad Freight Committee, Uniform Freight Classification, UFC-6000K, National Railroad Freight Committee, Chicago, Illinois, April 1994.

Office of Management and Budget, Management of Federal Information Resources, OMB-CIRC-A-130, Washington, D.C., December 12, 1985.

J. H. Portsmouth, J. E. Maxwell, and G. O. Boness, Motor Carrier Evaluation Program, WHC-EP-0336, Westinghouse Hanford Company, Richland, Washington, February 1990.

J. E. Ratledge, Guide for Wire Rope Tiedowns on Legal Weight Trucks for Packages Containing Radioactive Materials and Weighing Greater Than 5,000 Pounds, TMD/RCG001/Rev.1, Martin Marietta Energy Systems, Inc., Oak Ridge National Laboratory, Oak Ridge, Tennessee, January 1994.

U.S. Department of the Army, Department of Defense Explosives Hazard Classification Procedures, Technical Bulletin TB 700-2, U.S.Department of the Army, Washington, D.C., 1992.

U.S. Department of Energy, Department of Energy Explosives Safety Manual, Revision 7, DOE/EV/06194-3-REV7, Washington, D.C., April 1994.

U.S. Department of Energy, DOE Technical Standards List, Department of Energy Standards Index, DOE-TSL-1-94, Office of Nuclear Safety, Policy and Standards, Washington, D.C., March 1994. 
U.S. Department of Transportation, "Heliport Design," Advisory Circular 150/5390-2, Federal Aviation Administration, Washington, D.C., January 1988.

U.S. Department of Transportation, "Obstruction Marking and Lighting," Advisory Circular AC 70/7460-1H, Federal Aviation Administration, Washington, D.C., January 1994.

U.S. Department of Transportation, 1993 Emengency Response Guidebook, RSPA P 5800.6, Research and Special Programs Administration, Washington, D.C., 1993.

U.S. Nuclear Regulatory Commission, Qualification Criteria to Certify a Package for Air Transport of Plutonium, NUREG-0360, Washington, D.C., January 1978.

U.S. Nuclear Regulatory Commission, "Standard Format and Content of Part 71 Applications for Approval of Packaging of Type B, Large Quantity, and Fissile Radioactive Materials," Regulatory Guide 7.9 Rev.1, Washington, D.C., January 1980.

U.S. Nuclear Regulatory Commission, "Establishing Quality Assurance Programs for Packaging Used in the Transport of Radioactive Material," Regulatory Guide 7.10, Rev 1, Washington, D.C., June 1986.

U.S. Tariff Commission, Tariff Schedules of the United States Annotated, U.S. International Trade Commission, Washington, D.C., 1988.

\subsection{METRIC INFORMATION}

The following information is excerpted from a National Institute of Standards and Technology Notice in the Federal Register December 20, 1990, the ANSI/IEEE Standard 268-1992, the American Society for Testing and Materials Standard, ASTM E380-93, and the General Services Administration Federal Standard 376B. The latter reference lists the preferred metric units recommended for use throughout the federal government. For more detailed information concerning the references see the end of this section. 
The International System of Units is abbreviated SI (from the French name, Le Systeme International d'Unités). SI units are divided into three classes:

base units: seven units considered basic to SI and dimensionally independent. supplementary units: two dimensionless derived units of angular measure.

derived units: units derived by combining base units and supplementary units.

The following tables the base and dimensionless units SI units and conversions.

Table 1. Seven base SI units

\begin{tabular}{lll}
\hline \multirow{2}{*}{ Quantity } & \multicolumn{2}{c}{ SI unit } \\
\cline { 2 - 3 } & Name & Symbol \\
\hline Length & meter & $\mathrm{m}$ \\
Mass $^{a}$ & kilogram & $\mathrm{kg}$ \\
Time & second & $\mathrm{s}$ \\
Electric current & ampere & $\mathrm{A}$ \\
Thermodynamic temperature & kelvin & $\mathrm{K}$ \\
Amount of substance & mole & $\mathrm{mol}$ \\
Luminous intensity & candela & $\mathrm{cd}$ \\
\hline
\end{tabular}

Weight is commonly used to mean mass.

Table 2. Two supplementary units

\begin{tabular}{lll}
\hline \multirow{2}{*}{ Quantity } & \multicolumn{2}{c}{ SI Unit } \\
\cline { 2 - 3 } & Name & Symbol \\
\hline Plane angle & radian & rad \\
Solid angle & steradian & sr \\
\hline
\end{tabular}

Units for all other quantities are derived from these nine units. For example, in Table 3 are listed a number of SI derived units obtained from the base units. They are expressed as products and quotients of the seven base units without numerical factors. 
Table 3. Some SI-derived units

\begin{tabular}{lll}
\hline \multirow{2}{*}{ Quantity } & \multicolumn{2}{c}{ SI unit } \\
\cline { 2 - 3 } & \multicolumn{1}{c}{ Name } & Symbol \\
\hline Area & square meter & $\mathrm{m}^{2}$ \\
Volume & cubic meter & $\mathrm{m}^{3}$ \\
Speed, velocity & meter per second & $\mathrm{m} / \mathrm{s}$ \\
Acceleration & meter per second squared & $\mathrm{m} / \mathrm{s}^{2}$ \\
Wave number & reciprocal meter & $\mathrm{m}^{-1}$ \\
Density, mass & kilogram per cubic meter & $\mathrm{kg} / \mathrm{m}^{3}$ \\
Specific volume & cubic meter per kilogram & $\mathrm{m} 3 / \mathrm{kg}$ \\
Current density & ampere per square meter & $\mathrm{A} / \mathrm{m}^{2}$ \\
Magnetic field strength & ampere per meter & $\mathrm{A} / \mathrm{m}$ \\
Concentration (of amount of & mole per cubic meter & $\mathrm{mol} / \mathrm{m}^{3}$ \\
substance) & & \\
Luminance & candela per square meter & $\mathrm{cd} / \mathrm{m}^{2}$ \\
\hline
\end{tabular}

Certain derived units that have been given special names and symbols are listed in Table 4. They may themselves be used to express other derived units, as is also shown in Table 4. All the derived units given in the table have been obtained from the base and supplementary units. 
Table 4. Some SI-derived units with special names

\begin{tabular}{|c|c|c|c|}
\hline \multirow{2}{*}{ Quantity } & \multicolumn{3}{|c|}{ SI unit } \\
\hline & Name & Symbol & $\begin{array}{l}\text { Expression in terms } \\
\text { of other units }\end{array}$ \\
\hline Frequency & hertz & $\mathbf{H z}$ & $\mathrm{s}^{-1}$ \\
\hline Force & newton & $\mathbf{N}$ & $\mathrm{m} \cdot \mathrm{kg} / \mathrm{s}^{2}$ \\
\hline Pressure, stress & pascal & $\mathrm{Pa}$ & $\mathrm{N} / \mathrm{m}^{2}$ \\
\hline $\begin{array}{l}\text { Energy, work, quantity of } \\
\text { heat }\end{array}$ & joule & J & $\mathrm{N} \cdot \mathrm{m}$ \\
\hline Power, radiant flux & watt & $\mathbf{W}$ & $\mathrm{J} / \mathrm{s}$ \\
\hline $\begin{array}{l}\text { Electric charge, quantity of } \\
\text { electricity }\end{array}$ & coulomb & $\mathrm{C}$ & $\mathbf{s} \cdot \mathbf{A}$ \\
\hline $\begin{array}{l}\text { Electric potential, potential } \\
\text { difference, electromotive } \\
\text { force }\end{array}$ & volt & $\mathbf{V}$ & W/A \\
\hline Capacitance & farad & $\mathbf{F}$ & $\mathrm{C} / \mathrm{V}$ \\
\hline Electric resistance & ohm & $\mathbf{0}$ & V/A \\
\hline Electric conductance & siemens & $\mathbf{S}$ & AV \\
\hline Magnetic flux & weber & $\mathbf{W b}$ & Vs \\
\hline Magnetic flux density & tesla & $\mathrm{T}$ & $\mathrm{Wb} / \mathrm{m}^{2}$ \\
\hline Inductance & henry & $\mathbf{H}$ & $\mathbf{W b} / \mathrm{A}$ \\
\hline Celsius temperature & degree Celsius & ${ }^{\circ} \mathrm{C}$ & $\mathbf{K}$ \\
\hline Luminous flux & lumen & $\operatorname{lm}$ & cdsr \\
\hline Iluminance & $\operatorname{lux}$ & $\mathbf{x}$ & $\operatorname{lm} / \mathrm{m}^{2}$ \\
\hline Activity (of a radionuclide) & becquerel & $\mathbf{B q}$ & $s^{-1}$ \\
\hline $\begin{array}{l}\text { Absorbed dose, specific } \\
\text { energy imparted, kerma, } \\
\text { absorbed dose index }\end{array}$ & gray & Gy & $\mathrm{J} / \mathrm{kg}$ \\
\hline $\begin{array}{l}\text { Dose equivalent, dose } \\
\text { equivalent index }\end{array}$ & sievert & Sv & $\mathrm{J} / \mathrm{kg}$ \\
\hline
\end{tabular}

In addition to the thermodynamic temperature (symbol $T$ ) expressed in kelvins (see Table 1), use is also made of degree Celsius temperature (symbol $t$ ) defined by the equation, $t=T-T_{0}$, where $T_{0}=273.15 \mathrm{~K}$ by definition. To express Celsius, the unit "degree Celsius" which is equal to the unit "kelvin" is used; in this case, "degree Celsius" is a special name used in place of "kelvin." An interval or difference of degree Celsius temperature can, however, be expressed in kelvins as well as in degrees Celsius. 
Table 5 illustrates conversions for other units. The following example is a demonstration of the use of this table:

$$
\text { foot } \times 0.304=\text { meter }
$$

Table 5. Conversions for some other units

\begin{tabular}{lll}
\hline Conventional Unit From & Multiply by & SI units to \\
\hline foot (ft) & 0.304 & meter (m) \\
yard (yd) & 0.914 & meter (m) \\
inch (in) & 2.54 & centimeter (cm) \\
mile & 1.609 & kilometer (km) \\
nautical mile & 1.852 & kilometer (km) \\
acre & $4,046.9$ & square meter (m) \\
gallon (gal) & 3.785 & liter (L) \\
quart & 0.946 & liter (L) \\
mile per hour (mph) & 1.609 & kilometer per hour (km/h) \\
knot (nautical mile per hour) & 1.852 & kilometer per hour (km/h) \\
mile per gallon (mile/gal) & 0.425 & kilometer per liter (km/L) \\
ton (short) & 907.1 & kilogram (kg) \\
pound (lb) & 0.4536 & kilogram (kg) \\
pounds per square inch (psi) & 6.895 & kilopascal (kPa) \\
horsepower (hp) & 746 & watt (W) \\
curie (Ci) & 37,000 & megabecquerel (MBq) \\
rad & 0.01 & gray (Gy) \\
rem & 0.01 & sievert (Sv) \\
\hline
\end{tabular}

Table 6 gives the 16 prefixes used to form multiples and submultiples of the SI units. It is important to note that the kilogram is the only SI unit with a prefix as part of its name and symbol. Because double prefixes may not be used, in the case of mass, the prefixes of Table 6 are to be used with gram $(\mathrm{g})$ but not with kilogram $(\mathrm{kg})$. 
Table 6. SI prefixes

\begin{tabular}{ccc}
\hline Factor & Prefix & Symbol \\
\hline $10^{18}$ & exa & $\mathrm{E}$ \\
$10^{15}$ & peta & $\mathrm{P}$ \\
$10^{12}$ & tera & $\mathrm{T}$ \\
$10^{9}$ & giga & $\mathrm{G}$ \\
$10^{6}$ & mega & $\mathrm{M}$ \\
$10^{3}$ & kilo & $\mathrm{k}$ \\
$10^{2}$ & hecto & $\mathrm{h}$ \\
$10^{1}$ & deka & $\mathrm{da}$ \\
$10^{-1}$ & deci & $\mathrm{d}$ \\
$10^{-2}$ & centi & $\mathrm{c}$ \\
$10^{-3}$ & milli & $\mathrm{m}$ \\
$10^{-6}$ & micro & $\mu$ \\
$10^{-9}$ & nano & $\mathrm{n}$ \\
$10^{-12}$ & pico & $\mathrm{p}$ \\
$10^{-15}$ & femto & $\mathrm{f}$ \\
$10^{-18}$ & atto & $\mathrm{a}$ \\
\hline
\end{tabular}

Additional and more detailed information on the use of SI units is available in the following documents.

ANSI/IEEE Std 268-1992 (Revision of ANSI/IEEE Std 268-1982) , American National Standard for Metric Practice, 1992, Institute of Electrical \& Electronics Engineers (IEEE), 11 West 42nd Street, New York, N.Y. 10036.

ASTM E-380-93, Standard Practice for use of the International System of units (SI modernized Metric System), 1993, American Society for Testing and Materials, 1916 Race Street, Philadelphia, Pennsylvanian 19103-1187. 
Standards and Metric Practices Subcommittee of the U.S. Department of Commerce, National Institute of Standards and Technology, "Federal Standard 376B Preferred Metric Units for General Use by the Federal Government," Federal Standardization Handbook, General Services Administration, Washington, D.C., 20406, 1993.

U.S. Department of Commerce, National Institute of Standards and Technology, "Metric System of Measurement; Interpretation of the International System of Units for the United States," Fed. Reg., 55 (245), 52242-52245 (December 20, 1990). 
Appendix A

DOE DIRECTIVES CHECKLIST AS OF May 27, 1994 
DOE DIRECTIVES CHECKLIST AS OF 5-27-94

\begin{tabular}{|c|c|c|}
\hline DOE No. & Subject & Dated \\
\hline $1000.2 B$ & $\begin{array}{l}\text { Department Seal and Flag } \\
\text { (cancels DOE 1000.2A) }\end{array}$ & $05-18-92$ \\
\hline $1000.3 B$ & $\begin{array}{l}\text { Internal Control Systems } \\
\text { (cancels DOE 1000.3A) }\end{array}$ & $07-05-88$ \\
\hline \multirow[t]{2}{*}{1100.3} & Office of Hearings and Appeals & $09-15-78$ \\
\hline & Change 001 & 04-13-92 \\
\hline 1100.4 & $\begin{array}{l}\text { Organization and Functions-Board of } \\
\text { Contract Appeals }\end{array}$ & 03-01-79 \\
\hline $1100.6 \mathrm{~A}$ & $\begin{array}{l}\text { Departmental Organization Control } \\
\text { System } \\
\text { (cancels DOE 1100.6) }\end{array}$ & 06-08-92 \\
\hline 1130.4 & $\begin{array}{l}\text { Federal Women's Program Advisory } \\
\text { Councils }\end{array}$ & $12-23-81$ \\
\hline 1130.5 & $\begin{array}{l}\text { Hispanic Employment Program Advisory } \\
\text { Councils }\end{array}$ & 05-04-82 \\
\hline \multirow[t]{2}{*}{1130.6} & Advisory Committee Management & $09-23-82$ \\
\hline & Change 001 & $02-27-92$ \\
\hline $1130.8 \mathrm{~A}$ & $\begin{array}{l}\text { Data Integrity Board } \\
\text { (cancels DOE 1130.8) }\end{array}$ & $05-18-92$ \\
\hline \multirow[t]{2}{*}{$1220.1 A$} & $\begin{array}{l}\text { Congressional and Intergovernmental } \\
\text { Activities } \\
\text { (cancels DOE 1220.1) }\end{array}$ & 04-09-92 \\
\hline & Change 001 & $06-28-92$ \\
\hline 1230.2 & $\begin{array}{l}\text { American Indian Tribal Government } \\
\text { Policy }\end{array}$ & 04-08-92 \\
\hline \multirow[t]{2}{*}{$1240.2 B$} & $\begin{array}{l}\text { Unclassified Visits and Assignments by } \\
\text { Foreign Nationals } \\
\text { (cancels DOE 1240.2A) }\end{array}$ & 08-21-92 \\
\hline & Change 001 & $09-03-92$ \\
\hline 1270.1 & Funds-out Interagency Agreements & $06-13-79$ \\
\hline & Change 001 & 01-07-93 \\
\hline $1270.2 B$ & $\begin{array}{l}\text { Safeguards Agreement with the } \\
\text { International Atomic Energy Agency } \\
\text { (cancels DOE 1270.2A) }\end{array}$ & $06-23-92$ \\
\hline
\end{tabular}




\begin{tabular}{|c|c|c|}
\hline DOE No. & Subject & Dated \\
\hline $1300.2 \mathrm{~A}$ & $\begin{array}{l}\text { Department of Energy Technical } \\
\text { Standards Program } \\
\text { (cancels DOE 1300.2) }\end{array}$ & $05-19-92$ \\
\hline 1300.3 & $\begin{array}{l}\text { Policy on the Protection of Human } \\
\text { Subjects }\end{array}$ & $08-23-90$ \\
\hline $1322.2 \mathrm{C}$ & Forms Management & $10-22-91$ \\
\hline 1323.2B & $\begin{array}{l}\text { Interagency Reporting Requirements } \\
\text { (cancels DOE 1323.2A) }\end{array}$ & 04-09-92 \\
\hline \multirow[t]{2}{*}{$1324.2 \mathrm{~A}$} & $\begin{array}{l}\text { Records Disposition } \\
\text { (cancels DOE 1324.2) }\end{array}$ & 09-13-88 \\
\hline & Change 001 & 04-09-92 \\
\hline \multirow[t]{2}{*}{1324.3} & Files Management & 03-02-81 \\
\hline & Change 001 & 04-09-92 \\
\hline $1324.4 \mathrm{~A}$ & $\begin{array}{l}\text { Micrographics Management } \\
\text { (cancels DOE 1324.4) }\end{array}$ & $05-18-92$ \\
\hline $1324.5 \mathrm{~A}$ & $\begin{array}{l}\text { Records Management Program } \\
\text { (cancels DOE 1324.5) }\end{array}$ & 04-30-92 \\
\hline \multirow[t]{2}{*}{1324.6} & $\begin{array}{l}\text { Automated Office Electronic } \\
\text { Recordkeeping }\end{array}$ & 07-08-87 \\
\hline & Change 001 & $06-12-92$ \\
\hline 1324.8 & $\begin{array}{l}\text { Rights and Interests Records Protection } \\
\text { Program }\end{array}$ & 10-23-91 \\
\hline 1330.1D & $\begin{array}{l}\text { Computer Software Management } \\
\text { (cancels DOE 1330.1C) }\end{array}$ & 05-18-92 \\
\hline 1331.1D & $\begin{array}{l}\text { Procurement and Assistance Data System } \\
\text { (cancels DOE 1331.1C) }\end{array}$ & 05-18-92 \\
\hline 1331.2B & $\begin{array}{l}\text { Departmental Business Instrument } \\
\text { Numbering System } \\
\text { (cancels DOE 1331.2A) }\end{array}$ & 05-18-92 \\
\hline \multirow[t]{2}{*}{ 1332.1A } & $\begin{array}{l}\text { Uniform Reporting System } \\
\text { (cancels DOE 1332.1) }\end{array}$ & $10-15-85$ \\
\hline & Change 001 & 06-12-92 \\
\hline 1332.2 & $\begin{array}{l}\text { Uniform Reporting System for Federal } \\
\text { Assistance (Grants and Cooperative } \\
\text { Agreements) }\end{array}$ & $10-31-83$ \\
\hline
\end{tabular}




\begin{tabular}{|c|c|c|}
\hline DOE No. & Subject & Dated \\
\hline 1340.1B & $\begin{array}{l}\text { Management of Public Communications } \\
\text { Publications and Scientific, Technical, and } \\
\text { Engineering Publications } \\
\text { (cancels DOE 1340.1A) }\end{array}$ & 01-07-93 \\
\hline \multirow[t]{2}{*}{1350.1} & Audiovisual and Exhibits Management & $10-28-81$ \\
\hline & Change 001 & $03-26-84$ \\
\hline 1360.1B & $\begin{array}{l}\text { Acquisition and Management of } \\
\text { Computing Resources } \\
\text { (cancels DOE 1360.1A) }\end{array}$ & 01-07-93 \\
\hline 1360.2B & $\begin{array}{l}\text { Unclassified Computer Security Program } \\
\text { (cancels DOE 1360.2A) }\end{array}$ & $05-18-92$ \\
\hline $1360.3 C$ & $\begin{array}{l}\text { Information Technology Standards } \\
\text { (cancels DOE 1360.3B DOE N 1360.8) }\end{array}$ & $10-19-92$ \\
\hline 1360.4B & $\begin{array}{l}\text { Scientific and Technical Computer } \\
\text { Software } \\
\text { (cancels DOE 1360.4A) }\end{array}$ & 12-31-91 \\
\hline $1360.6 \mathrm{~A}$ & $\begin{array}{l}\text { Automatic Data Processing } \\
\text { Equipment/Data Systems } \\
\text { (cancels DOE 1360.6) }\end{array}$ & $11-12-92$ \\
\hline $1360.8 \mathrm{~A}$ & $\begin{array}{l}\text { Analyses of Benefits and Costs for } \\
\text { Information Technology Resources } \\
\text { Initiatives } \\
\text { (cancels DOE 1360.8) }\end{array}$ & 05-18-92 \\
\hline 1410.2 & Mail Management & $04-29-85$ \\
\hline $1430.1 C$ & $\begin{array}{l}\text { Management of Scientific and Technical } \\
\text { Information } \\
\text { (cancels DOE 1430.1B) }\end{array}$ & $02-27-92$ \\
\hline $1430.2 B$ & $\begin{array}{l}\text { Scientific and Technical Information } \\
\text { Management Program } \\
\text { (cancels DOE 1430.2A) }\end{array}$ & $02-25-93$ \\
\hline \multirow[t]{2}{*}{$1430.3 A$} & $\begin{array}{l}\text { Policy for the Dissemination of the Access } \\
\text { to Departmental Unclassified Scientific } \\
\text { and Technical Information } \\
\text { (cancels DOE 1430.3) }\end{array}$ & 02-27-92 \\
\hline & Change 001 & 05-14-92 \\
\hline $1430.4 \mathrm{~A}$ & $\begin{array}{l}\text { Library Services } \\
\text { (cancels DOE 1430.4) }\end{array}$ & 05-18-92 \\
\hline
\end{tabular}




\begin{tabular}{|c|c|c|}
\hline DOE No. & Subject & Dated \\
\hline $1450.1 \mathrm{C}$ & $\begin{array}{l}\text { Acquisition, Utilization, and } \\
\text { Administration of Teleprocessing Services } \\
\text { (cancels DOE 1450.1B) }\end{array}$ & 09-03-86 \\
\hline \multirow[t]{2}{*}{$1450.3 \mathrm{~A}$} & $\begin{array}{l}\text { Call Control/Verification Programs and } \\
\text { Authorized Use of Government } \\
\text { Telephone Systems } \\
\text { (cancels DOE 1450.3) }\end{array}$ & 09-12-91 \\
\hline & Change 001 & 04-09-92 \\
\hline 1450.4 & $\begin{array}{l}\text { Consensual Listening-In to or Recording } \\
\text { Telephone/Radio Conversations }\end{array}$ & $11-12-92$ \\
\hline \multirow[t]{12}{*}{$1500.2 \mathrm{~A}$} & $\begin{array}{l}\text { Travel Policy and Procedures } \\
\text { (cancels DOE 1500.2) }\end{array}$ & $06-07-89$ \\
\hline & Change 001 & $09-27-89$ \\
\hline & Change 002 & 02-07-90 \\
\hline & Change 003 & 03-15-90 \\
\hline & Change 004 & $06-19-90$ \\
\hline & Change 005 & 01-11-91 \\
\hline & Change 006 & 03-19-91 \\
\hline & Change 007 & $06-20-91$ \\
\hline & Change 008 & 07-31-91 \\
\hline & Change 009 & 04-01-92 \\
\hline & Change 010 & $06-12-92$ \\
\hline & Change 011 & $04-16-93$ \\
\hline \multirow[t]{7}{*}{1500.3} & $\begin{array}{l}\text { Foreign Travel Authorization } \\
\text { (cancels DOE 5638.1; and Chapter VIII of } \\
\text { DOE 1500.2) }\end{array}$ & $11-10-86$ \\
\hline & Change 001 & $02-05-87$ \\
\hline & Change 002 & $06-17-87$ \\
\hline & Change 003 & $12-22-87$ \\
\hline & Change 004 & $03-30-89$ \\
\hline & Change 005 & $05-18-90$ \\
\hline & Change 006 & $02-28-92$ \\
\hline $1500.4 \mathrm{~A}$ & $\begin{array}{l}\text { Travel Charge Card Program } \\
\text { (cancels DOE 1500.4) }\end{array}$ & 04-22-91 \\
\hline
\end{tabular}




\begin{tabular}{|c|c|c|}
\hline DOE No. & Subject & Dated \\
\hline & Change 001 & 09-15-92 \\
\hline $1540.1 \mathrm{~A}$ & $\begin{array}{l}\text { Materials Transportation and Traffic } \\
\text { Management } \\
\text { (cancels DOE 1540.1) }\end{array}$ & 07-08-92 \\
\hline \multirow[t]{2}{*}{1540.2} & $\begin{array}{l}\text { Hazardous Material Packaging for } \\
\text { Transport-Administrative Procedures }\end{array}$ & 09-30-86 \\
\hline & Change 001 & $12-19-88$ \\
\hline $1540.3 \mathrm{~A}$ & $\begin{array}{l}\text { Base Technology for Radioactive Material } \\
\text { Transportation Packaging Systems } \\
\text { (cancels DOE 1540.3) }\end{array}$ & 07-08-92 \\
\hline 1600.1A & $\begin{array}{l}\text { Federal Women's Program } \\
\text { (cancels DOE 1600.1) }\end{array}$ & 05-14-92 \\
\hline 1600.2B & $\begin{array}{l}\text { Secretary's Commitment to Equal } \\
\text { Opportunity } \\
\text { (cancels DOE 1600.2A) }\end{array}$ & $06-14-85$ \\
\hline 1600.3 & Policy on Sexual Harassment & $06-15-81$ \\
\hline 1600.4 & Hispanic Employment Program & $02-02-82$ \\
\hline 1600.5 & $\begin{array}{l}\text { System for Processing Complaints of } \\
\text { Discrimination }\end{array}$ & $05-26-82$ \\
\hline $1600.6 \mathrm{~A}$ & $\begin{array}{l}\text { Civil Rights Compliance in Federally } \\
\text { Assisted Programs } \\
\text { (cancels DOE 1600.6) }\end{array}$ & 05-14-92 \\
\hline \multirow[t]{5}{*}{1700.1} & Freedom of Information Program & $11-19-79$ \\
\hline & Change 001 & $10-08-81$ \\
\hline & Change 002 & $04-05-92$ \\
\hline & Change 003 & $05-18-92$ \\
\hline & Change 004 & 08-21-92 \\
\hline \multirow[t]{2}{*}{$1800.1 \mathrm{~A}$} & $\begin{array}{l}\text { Privacy Act } \\
\text { (cancels DOE 1800.1) }\end{array}$ & 08-31-84 \\
\hline & Change 001 & $05-18-92$ \\
\hline 2020.2 & $\begin{array}{l}\text { Legislative Coordination and Clearance } \\
\text { Process }\end{array}$ & 09-28-79 \\
\hline \multirow[t]{2}{*}{2030.2} & $\begin{array}{l}\text { Dissemination of Departmental } \\
\text { Regulations on Acceptance of Gifts and } \\
\text { Travel From Foreign Governments }\end{array}$ & $04-08-81$ \\
\hline & Change 001 & $05-18-92$ \\
\hline
\end{tabular}




\begin{tabular}{|c|c|c|}
\hline DOE No. & Subject & Dated \\
\hline \multirow[t]{2}{*}{2030.3} & Federalism Guidelines & $09-29-89$ \\
\hline & Change 001 & $05-14-92$ \\
\hline 2030.4B & $\begin{array}{l}\text { Reporting Fraud, Waste, and Abuse } \\
\text { to the Office of Inspector General } \\
\text { (cancels DOE 2030.4A) }\end{array}$ & $05-18-92$ \\
\hline $2100.3 \mathrm{~A}$ & $\begin{array}{l}\text { Transfer of Contracts Between } \\
\text { Departmental Elements } \\
\text { (cancels DOE 2100.3) }\end{array}$ & 06-08-92 \\
\hline $2100.8 \mathrm{~A}$ & $\begin{array}{l}\text { Cost Accounting, Cost Recovery, and } \\
\text { Interagency Sharing of Information } \\
\text { Technology Facilities } \\
\text { (cancels DOE 2100.8) }\end{array}$ & $01-27-93$ \\
\hline $2100.12 A$ & $\begin{array}{l}\text { Payments for Special Burdens and in Lieu } \\
\text { of Taxes } \\
\text { (cancels DOE 2100.12) }\end{array}$ & $06-09-92$ \\
\hline \multirow[t]{3}{*}{$2110.1 \mathrm{~A}$} & $\begin{array}{l}\text { Pricing of Departmental Materials and } \\
\text { Services } \\
\text { (cancels DOE 2110.1) }\end{array}$ & $07-14-88$ \\
\hline & Change 001 & $10-05-88$ \\
\hline & Change 002 & 05-18-92 \\
\hline $2200.2 B$ & $\begin{array}{l}\text { Collection from Current and Former } \\
\text { Employees for Indebtedness to the United } \\
\text { States } \\
\text { (cancels DOE 2200.2A) }\end{array}$ & $06-09-92$ \\
\hline \multirow[t]{2}{*}{2200.4} & $\begin{array}{l}\text { Accounting Overview } \\
\text { (cancels DOE 2100.1A, DOE 2200.1) }\end{array}$ & $03-31-88$ \\
\hline & Change 001 & $06-08-92$ \\
\hline \multirow[t]{5}{*}{$2200.5 B$} & $\begin{array}{l}\text { Fund Accounting } \\
\text { (cancels DOE 2200.5A) }\end{array}$ & $06-08-92$ \\
\hline & Change 001 & $11-12-92$ \\
\hline & Change 002 & 04-02-93 \\
\hline & Change 003 & $06-14-93$ \\
\hline & Change 004 & 08-16-93 \\
\hline \multirow[t]{2}{*}{$2200.6 \mathrm{~A}$} & $\begin{array}{l}\text { Financial Accounting } \\
\text { (cancels DOE 2200.6) }\end{array}$ & 01-07-93 \\
\hline & Change 001 & 04-13-93 \\
\hline 2200.7 & Cost Accounting & $05-02-88$ \\
\hline
\end{tabular}




\begin{tabular}{|c|c|c|}
\hline DOE No. & Subject & Dated \\
\hline $2200.8 \mathrm{~B}$ & $\begin{array}{l}\text { Accounting Systems, Organizations and } \\
\text { Reporting } \\
\text { (cancels DOE 2200.8A) }\end{array}$ & 06-08-92 \\
\hline \multirow[t]{4}{*}{$2200.9 B$} & $\begin{array}{l}\text { Miscellaneous Accounting } \\
\text { (cancels DOE 2200.9A) }\end{array}$ & $06-08-92$ \\
\hline & Change 001 & $11-12-92$ \\
\hline & Change 002 & $01-12-93$ \\
\hline & Change 003 & 02-23-93 \\
\hline \multirow[t]{7}{*}{$2200.10 \mathrm{~A}$} & $\begin{array}{l}\text { Accounts, Codes, and Illustrative Entries } \\
\text { (cancels DOE 2200.10) }\end{array}$ & 08-09-89 \\
\hline & Change 001 & $02-27-90$ \\
\hline & Change 002 & $10-17-90$ \\
\hline & Change 003 & $01-15-92$ \\
\hline & Change 004 & $06-08-92$ \\
\hline & Change 005 & $03-10-93$ \\
\hline & Change 006 & $08-16-93$ \\
\hline \multirow[t]{2}{*}{2200.11} & $\begin{array}{l}\text { Processing Garnishment Orders for Child } \\
\text { Support and/or Alimony }\end{array}$ & $02-12-88$ \\
\hline & Change 001 & $05-03-90$ \\
\hline $2200.12 \mathrm{~A}$ & $\begin{array}{l}\text { Financial Management Systems } \\
\text { (cancels DOE 2200.12) }\end{array}$ & $05-14-92$ \\
\hline 2200.13 & $\begin{array}{l}\text { Oversight of Integrated Contractor } \\
\text { Financial Management }\end{array}$ & 09-27-91 \\
\hline 2300.1B & $\begin{array}{l}\text { Audit Resolution and Followup } \\
\text { (cancels DOE 2300.1A) }\end{array}$ & 06-08-92 \\
\hline 2320.1C & $\begin{array}{l}\text { Cooperation with the Office of Inspector } \\
\text { General } \\
\text { (cancels DOE 2320.1B) }\end{array}$ & 05-18-92 \\
\hline 2320.2B & $\begin{array}{l}\text { Establishment of Departmental Position } \\
\text { on Inspector General Reports } \\
\text { (cancels DOE 2320.2A) }\end{array}$ & 05-18-92 \\
\hline $2320.3 A$ & $\begin{array}{l}\text { Office of Inspector } \\
\text { General-Responsibilities, Authorities, and } \\
\text { Relationships with Other Departmental } \\
\text { Elements } \\
\text { (cancels DOE 2320.3) }\end{array}$ & 05-18-92 \\
\hline
\end{tabular}




\begin{tabular}{|c|c|c|}
\hline DOE No. & Subject & Dated \\
\hline 2321.1B & $\begin{array}{l}\text { Auditing of Programs and Operations } \\
\text { (cancels DOE 2321.1A) }\end{array}$ & 05-14-92 \\
\hline $2340.1 C$ & $\begin{array}{l}\text { Coordination of General Accounting } \\
\text { Office Activities } \\
\text { (cancels DOE 2340.1B) }\end{array}$ & 06-08-92 \\
\hline 3220.1A & $\begin{array}{l}\text { Management of Contractor Personnel } \\
\text { Policies and Programs } \\
\text { (cancels DOE 3220.1) }\end{array}$ & 05-14-92 \\
\hline $3220.2 \mathrm{~A}$ & $\begin{array}{l}\text { Equal Opportunity in Operating and } \\
\text { Onsite Service Contractor Facilities } \\
\text { (cancels DOE 3220.2) }\end{array}$ & 05-14-92 \\
\hline $3220.3 A$ & $\begin{array}{l}\text { Human Resource Development for } \\
\text { Management and Operating Contractors } \\
\text { (cancels DOE 3220.3) }\end{array}$ & 05-18-92 \\
\hline $3220.4 \mathrm{~A}$ & $\begin{array}{l}\text { Contractor Personnel and Industrial } \\
\text { Relations Reports } \\
\text { (cancels DOE 3220.4) }\end{array}$ & $01-07-93$ \\
\hline $3220.5 \mathrm{~A}$ & $\begin{array}{l}\text { Payment of Wages or Salaries to Cost- } \\
\text { Type Contractor Employees When Access } \\
\text { Authorization is suspended } \\
\text { (cancels DOE 3220.5) }\end{array}$ & $06-12-92$ \\
\hline $3220.6 \mathrm{~A}$ & $\begin{array}{l}\text { Federal Labor Standards } \\
\text { (cancels DOE 3220.6) }\end{array}$ & $05-14-92$ \\
\hline $3240.2 A$ & $\begin{array}{l}\text { Utilization of Military Personnel } \\
\text { (cancels DOE 3240.2) }\end{array}$ & 06-23-92 \\
\hline 3300.1B & $\begin{array}{l}\text { Assignment of Departmental Personnel } \\
\text { Outside the Department } \\
\text { (cancels DOE 3300.1A) }\end{array}$ & $06-23-92$ \\
\hline $3300.2 A$ & $\begin{array}{l}\text { Affirmative Action Program for } \\
\text { Handicapped Persons } \\
\text { (cancels DOE 3300.2) }\end{array}$ & 05-18-92 \\
\hline 3304.1A & $\begin{array}{l}\text { Employment of Experts and Consultants } \\
\text { (cancels DOE 3304.1) }\end{array}$ & $06-23-92$ \\
\hline 3305.1 & $\begin{array}{l}\text { Presidential, Supergrade, and Schedule C } \\
\text { Positions }\end{array}$ & $07-31-81$ \\
\hline \multirow[t]{2}{*}{3305.2} & Senior Executive Service-Employment & $08-11-81$ \\
\hline & Change 001 & $09-23-83$ \\
\hline 3309.1A & $\begin{array}{l}\text { Reductions in Contractor Employment } \\
\text { (cancels DOE 3309.1) }\end{array}$ & $11-30-92$ \\
\hline
\end{tabular}




\begin{tabular}{|c|c|c|}
\hline DOE No. & Subject & Dated \\
\hline 3309.3 & $\begin{array}{l}\text { Utilization of Individual Consultants by } \\
\text { Contractors }\end{array}$ & $05-07-93$ \\
\hline 3315.1A & $\begin{array}{l}\text { Probationary Period for Managers and } \\
\text { Supervisors } \\
\text { (cancels DOE 3315.1) }\end{array}$ & $06-23-92$ \\
\hline $3330.1 \mathrm{~A}$ & $\begin{array}{l}\text { Federal Equal Opportunity Recruitment } \\
\text { Program } \\
\text { (cancels DOE 3330.1) }\end{array}$ & $05-18-92$ \\
\hline \multirow[t]{3}{*}{3330.2} & Priority Placement and Consideration & $10-08-86$ \\
\hline & Change 001 & $02-05-87$ \\
\hline & Change 002 & 06-23-92 \\
\hline $3335.1 \mathrm{C}$ & $\begin{array}{l}\text { Merit Promotion } \\
\text { (cancels DOE 3335.1B) }\end{array}$ & $06-23-92$ \\
\hline $3340.1 \mathrm{~A}$ & $\begin{array}{l}\text { Part-Time Career Employment Program } \\
\text { (cancels DOE 3340.1) }\end{array}$ & 05-14-92 \\
\hline \multirow[t]{2}{*}{3350.1} & Furlough in the Senior Executive Service & 09-13-82 \\
\hline & Change 001 & $11-23-84$ \\
\hline $3351.1 \mathrm{C}$ & $\begin{array}{l}\text { Reduction in Force } \\
\text { (cancels DOE 3351.1B) }\end{array}$ & $06-23-92$ \\
\hline \multirow[t]{2}{*}{3351.2} & $\begin{array}{l}\text { Reduction in Force in Senior Executive } \\
\text { Service }\end{array}$ & $11-27-81$ \\
\hline & Change 001 & $04-07-82$ \\
\hline \multirow[t]{3}{*}{ 3410.1B } & $\begin{array}{l}\text { Training } \\
\text { (cancels DOE 3410.1A) }\end{array}$ & $02-29-88$ \\
\hline & Change 001 & $10-18-89$ \\
\hline & Change 002 & 05-18-92 \\
\hline \multirow[t]{3}{*}{$3410.2 A$} & $\begin{array}{l}\text { Upward Mobility Program } \\
\text { (cancels DOE 3410,2) }\end{array}$ & 04-09-87 \\
\hline & Change 001 & $02-09-88$ \\
\hline & Change 002 & $10-24-89$ \\
\hline \multirow[t]{3}{*}{ 3430.3A } & $\begin{array}{l}\text { Departmental Performance Appraisal } \\
\text { System } \\
\text { (cancels DOE 3430.3) }\end{array}$ & $08-14-86$ \\
\hline & Change 001 & $05-14-92$ \\
\hline & Change 002 & $07-22-92$ \\
\hline
\end{tabular}




\begin{tabular}{|c|c|c|}
\hline DOE No. & Subject & Dated \\
\hline $3430.4 \mathrm{~A}$ & $\begin{array}{l}\text { Senior Executive Service Performance } \\
\text { Appraisal System } \\
\text { (cancels DOE 3430.4) }\end{array}$ & $08-24-84$ \\
\hline 3450.1B & $\begin{array}{l}\text { Incentive Awards } \\
\text { (cancels DOE 3450.1A) }\end{array}$ & 06-23-92 \\
\hline $3510.1 \mathrm{~A}$ & $\begin{array}{l}\text { Position Management } \\
\text { (cancels DOE 3510.1) }\end{array}$ & $06-23-92$ \\
\hline \multirow[t]{2}{*}{ 3511.1A } & $\begin{array}{l}\text { Position Classification } \\
\text { (cancels DOE 3511.1) }\end{array}$ & $10-01-84$ \\
\hline & Change 001 & $07-08-92$ \\
\hline \multirow[t]{3}{*}{ 3540.1A } & $\begin{array}{l}\text { Performance Management and } \\
\text { Recognition System } \\
\text { (cancels DOE 3540.1) }\end{array}$ & 08-14-86 \\
\hline & Change 001 & $03-16-92$ \\
\hline & Change 002 & $05-18-92$ \\
\hline \multirow[t]{3}{*}{$3550.1 \mathrm{~A}$} & $\begin{array}{l}\text { Pay Administration and Hours of Duty } \\
\text { (cancels DOE 3550.1) }\end{array}$ & $12-22-87$ \\
\hline & Change 001 & $07-16-90$ \\
\hline & Change 002 & $08-21-92$ \\
\hline \multirow[t]{3}{*}{ 3600.1B } & $\begin{array}{l}\text { Time and Attendance Reporting } \\
\text { (cancels DOE 3600.1A) }\end{array}$ & $02-11-91$ \\
\hline & Change 001 & 12-09-91 \\
\hline & Change 002 & 04-23-92 \\
\hline 3630.1B & $\begin{array}{l}\text { Leave Administration } \\
\text { (cancels DOE 3630.1A) }\end{array}$ & $12-31-86$ \\
\hline 3630.2 & Voluntary Leave Transfer Program & 09-19-89 \\
\hline \multirow[t]{2}{*}{ 3710.1A } & $\begin{array}{l}\text { Labor-Management Relations Program for } \\
\text { Federal Employees } \\
\text { (cancels DOE 3710.1) }\end{array}$ & 09-30-86 \\
\hline & Change 001 & 05-18-92 \\
\hline \multirow[t]{2}{*}{3731.1} & $\begin{array}{l}\text { Suitability, Position Sensitivity } \\
\text { Designations, and Related Personnel } \\
\text { Matters }\end{array}$ & $12-19-89$ \\
\hline & Change 001 & 07-08-92 \\
\hline 3733.1 & $\begin{array}{l}\text { Employee Participation in Political } \\
\text { Activities }\end{array}$ & $07-05-84$ \\
\hline
\end{tabular}




\begin{tabular}{|c|c|c|}
\hline DOE No. & Subject & Dated \\
\hline 3735.1 & $\begin{array}{l}\text { Dissemination of the Departmental } \\
\text { Conduct of Employees Regulations }\end{array}$ & $05-01-80$ \\
\hline \multirow[t]{7}{*}{3750.1} & Work Force Discipline & $03-23-83$ \\
\hline & Change 001 & 03-11-85 \\
\hline & Change 002 & $01-06-86$ \\
\hline & Change 003 & 03-21-89 \\
\hline & Change 004 & 08-24-90 \\
\hline & Change 005 & 03-09-92 \\
\hline & Change 006 & $08-21-92$ \\
\hline \multirow[t]{4}{*}{3771.1} & Grievance Policy and Procedures & $07-02-81$ \\
\hline & Change 001 & $11-29-83$ \\
\hline & Change 002 & 08-13-85 \\
\hline & Change 003 & 08-21-92 \\
\hline 3790.1B & $\begin{array}{l}\text { Federal Employee Occupational Safety } \\
\text { and Health Program } \\
\text { (cancels DOE 3790.1A) }\end{array}$ & 01-07-93 \\
\hline \multirow[t]{2}{*}{ 3791.2A } & $\begin{array}{l}\text { Federal Employee Motor Vehicle Safety } \\
\text { Program } \\
\text { (cancels DOE 3791.2) }\end{array}$ & $12-24-86$ \\
\hline & Change 001 & 08-21-92 \\
\hline 3792.1A & $\begin{array}{l}\text { Employee Assistance Program } \\
\text { (cancels DOE 3792.1) }\end{array}$ & 05-14-92 \\
\hline \multirow[t]{2}{*}{3792.3} & $\begin{array}{l}\text { Drug-Free Federal Workplace Testing } \\
\text { Implementation Program }\end{array}$ & $07-29-88$ \\
\hline & Change 001 & 08-21-92 \\
\hline 3830.1 & $\begin{array}{l}\text { Policies and Procedures for Pension } \\
\text { Programs Under Operating and Onsite } \\
\text { Service Contractors }\end{array}$ & 08-23-82 \\
\hline 3890.1A & $\begin{array}{l}\text { Contractor Insurance and Other Health } \\
\text { Benefit Programs } \\
\text { (cancels DOE 3890.1) }\end{array}$ & $06-12-92$ \\
\hline $3900.1 B$ & $\begin{array}{l}\text { Parking } \\
\text { (cancels DOE 3900.1A) }\end{array}$ & 05-18-92 \\
\hline 4010.1A & $\begin{array}{l}\text { Value Engineering } \\
\text { (cancels DOE 4010.1) }\end{array}$ & 05-14-92 \\
\hline
\end{tabular}




\begin{tabular}{|c|c|c|}
\hline DOE No. & Subject & Dated \\
\hline $4200.1 \mathrm{C}$ & $\begin{array}{l}\text { Competition in Contracting } \\
\text { (cancels DOE 4200.1B) }\end{array}$ & $01-09-87$ \\
\hline 4200.3D & $\begin{array}{l}\text { Management of Support Services Contract } \\
\text { Activity } \\
\text { (cancels DOE } 4200.3 \mathrm{C} \text { ) }\end{array}$ & $08-31-92$ \\
\hline \multirow[t]{2}{*}{$4200.4 A$} & $\begin{array}{l}\text { Selection, Appointment, and Termination } \\
\text { of Appointment of Contracting Officers } \\
\text { (cancels DOE 4200.4) }\end{array}$ & $08-21-89$ \\
\hline & Change 001 & $02-14-92$ \\
\hline $4210.1 \mathrm{C}$ & $\begin{array}{l}\text { Designation of Source Selection Officials } \\
\text { (cancels DOE 4210.1B) }\end{array}$ & $05-18-92$ \\
\hline $4210.5 A$ & $\begin{array}{l}\text { Operating and Onsite Service Contract } \\
\text { Extend or Compete Decisions } \\
\text { (cancels DOE 4210.5) }\end{array}$ & $06-23-92$ \\
\hline $4210.7 B$ & $\begin{array}{l}\text { Indirect Cost Rate Responsibilities } \\
\text { (cancels DOE 4210.7A, 4210.8, and } \\
\text { 4220.1) }\end{array}$ & $12-24-91$ \\
\hline $4210.9 A$ & $\begin{array}{l}\text { Unsolicited Proposals } \\
\text { (cancels DOE 4210.9) }\end{array}$ & $01-06-93$ \\
\hline 4220.4 & $\begin{array}{l}\text { Organizational Conflict of Interest } \\
\text { Processing Procedures }\end{array}$ & $05-19-86$ \\
\hline 4220.5 & $\begin{array}{l}\text { Dependent Care Programs for the } \\
\text { Department of Energy Management and } \\
\text { Operating Contracts }\end{array}$ & $12-19-91$ \\
\hline $4240.1 \mathrm{~K}$ & $\begin{array}{l}\text { Designation of Major System Acquisitions } \\
\text { and Major Products } \\
\text { (cancels DOE 4240.1J) }\end{array}$ & 06-23-92 \\
\hline $4250.1 \mathrm{~A}$ & $\begin{array}{l}\text { Small Business/Labor Surplus Area Set- } \\
\text { Aside and 8(A) Program Review } \\
\text { Procedures } \\
\text { (cancels DOE 4250.1) }\end{array}$ & $02-27-92$ \\
\hline $4300.1 \mathrm{C}$ & $\begin{array}{l}\text { Real Property Management } \\
\text { (cancels DOE 4300.1B, DOE 4320.1A) }\end{array}$ & $06-28-92$ \\
\hline \multirow[t]{3}{*}{$4300.2 B$} & $\begin{array}{l}\text { Non-Department of Energy Funded Work } \\
\text { (Work for Others) } \\
\text { (cancels DOE 4300.2A) }\end{array}$ & $07-16-91$ \\
\hline & Change 001 & $07-29-91$ \\
\hline & Change 002 & $02-07-92$ \\
\hline
\end{tabular}




\begin{tabular}{|c|c|c|}
\hline DOE No. & Subject & Dated \\
\hline & Change 003 & 01-07-93 \\
\hline \multirow[t]{2}{*}{ 4320.1B } & $\begin{array}{l}\text { Site Development Planning } \\
\text { (cancels Chapters } 1 \text { and } 2 \text { of DOE } \\
\text { 4300.1B) }\end{array}$ & $01-07-91$ \\
\hline & Change 001 & $03-26-92$ \\
\hline $4320.2 \mathrm{~A}$ & $\begin{array}{l}\text { Capital Asset Management Process } \\
\text { (cancels DOE 4320.2) }\end{array}$ & $02-10-94$ \\
\hline 4330.2D & $\begin{array}{l}\text { In-House Energy Management } \\
\text { (cancels DOE 4330.2C) }\end{array}$ & 05-18-92 \\
\hline \multirow[t]{5}{*}{ 4330.4B } & $\begin{array}{l}\text { Maintenance Management Program } \\
\text { (cancels DOE 4330.4A) }\end{array}$ & $02-10-94$ \\
\hline & Change 001 & $04-09-91$ \\
\hline & Change 002 & $06-20-91$ \\
\hline & Change 003 & $01-06-92$ \\
\hline & Change 004 & 05-18-92 \\
\hline 4540.1C & $\begin{array}{l}\text { Utility Acquisition and Management } \\
\text { (cancels DOE 4540.1B) }\end{array}$ & $06-08-92$ \\
\hline $4600.1 A$ & $\begin{array}{l}\text { Financial Assistance Procedures Manual } \\
\text { (cancels DOE 4600.1) }\end{array}$ & $04-01-87$ \\
\hline \multirow[t]{2}{*}{4700.1} & $\begin{array}{l}\text { Project Management System } \\
\text { (cancels DOE 4210.2, 5700.1C, 5700.3B, } \\
5700.4 \mathrm{~A} \text {, and 6410.1) }\end{array}$ & $03-06-87$ \\
\hline & Change 001 & $06-02-92$ \\
\hline 4700.2 & Mission Area Assignments & $07-07-87$ \\
\hline \multirow[t]{2}{*}{4700.3} & General Plant Projects & $09-16-91$ \\
\hline & Change 001 & $11-16-92$ \\
\hline 4700.4 & Project Manager Certification & $01-27-93$ \\
\hline $5000.1 B$ & $\begin{array}{l}\text { Institutional Planning by Multiprogram } \\
\text { Laboratories } \\
\text { (cancels DOE 5000.1A) }\end{array}$ & 04-09-92 \\
\hline $5000.2 \mathrm{~B}$ & $\begin{array}{l}\text { Multiprogram Laboratory Appraisals } \\
\text { (cancels DOE 5000.2A) }\end{array}$ & 04-09-92 \\
\hline \multirow[t]{2}{*}{$5000.3 B$} & $\begin{array}{l}\text { Occurrence Reporting and Processing of } \\
\text { Operations Information } \\
\text { (cancels DOE 5000.3A) }\end{array}$ & 01-19-93 \\
\hline & Change 001 & 07-02-93 \\
\hline
\end{tabular}




\begin{tabular}{|c|c|c|}
\hline DOE No. & Subject & Dated \\
\hline $5000.4 \mathrm{~A}$ & $\begin{array}{l}\text { Laboratory Directed Research and } \\
\text { Development } \\
\text { (cancels DOE 5000.4) }\end{array}$ & 04-09-92 \\
\hline 5100.3 & Field Budget Process & $08-23-84$ \\
\hline 5100.4 & Internal Review Budget Process & $10-31-84$ \\
\hline 5100.5 & $\begin{array}{l}\text { Office of Management and } \\
\text { Budget-Budget Process }\end{array}$ & $07-21-83$ \\
\hline $5100.6 \mathrm{~A}$ & $\begin{array}{l}\text { Congressional Budget Review } \\
\text { (cancels DOE 5100.6) }\end{array}$ & $05-18-92$ \\
\hline $5100.11 \mathrm{~A}$ & $\begin{array}{l}\text { Budget Execution-Office of Management } \\
\text { and Budget Apportionment and Treasury } \\
\text { Warrant Process } \\
\text { (cancels DOE 5100.11) }\end{array}$ & $05-18-92$ \\
\hline $5100.12 A$ & $\begin{array}{l}\text { Budget Execution-Department of Energy } \\
\text { Base Table } \\
\text { (cancels DOE 5100.12) }\end{array}$ & 05-14-92 \\
\hline $5100.13 A$ & $\begin{array}{l}\text { Budget Execution-Rescissions and } \\
\text { Deferrals } \\
\text { (cancels DOE 5100.13) }\end{array}$ & $05-18-92$ \\
\hline $5100.14 A$ & $\begin{array}{l}\text { Allotment and Approval Funding Program } \\
\text { Process } \\
\text { (cancels DOE 5100.14) }\end{array}$ & $05-18-92$ \\
\hline $5160.1 \mathrm{~B}$ & $\begin{array}{l}\text { Reprogramming, Restructuring, and } \\
\text { Appropriation Transfer Procedures } \\
\text { (cancels DOE 5160.1A) }\end{array}$ & 05-18-92 \\
\hline $5300.1 \mathrm{C}$ & $\begin{array}{l}\text { Telecommunications } \\
\text { (cancels DOE 5300.1B) }\end{array}$ & $06-12-92$ \\
\hline $5300.2 \mathrm{D}$ & $\begin{array}{l}\text { Telecommunications: Emission Security } \\
\text { (Tempest) } \\
\text { (cancels DOE 5300.2C) }\end{array}$ & 05-18-92 \\
\hline $5300.3 \mathrm{D}$ & $\begin{array}{l}\text { Telecommunications: Communications } \\
\text { Security } \\
\text { (cancels DOE 5300.3C) }\end{array}$ & 08-03-93 \\
\hline $5300.4 \mathrm{D}$ & $\begin{array}{l}\text { Telecommunications: Protected } \\
\text { Distribution Systems } \\
\text { (cancels DOE 5300.4C) }\end{array}$ & 03-04-94 \\
\hline \multirow[t]{2}{*}{5400.1} & $\begin{array}{l}\text { General Environmental Protection } \\
\text { Program }\end{array}$ & $11-09-88$ \\
\hline & Change 001 & $06-29-90$ \\
\hline
\end{tabular}




\begin{tabular}{|c|c|c|}
\hline DOE No. & Subject & Dated \\
\hline \multirow[t]{2}{*}{$5400.2 \mathrm{~A}$} & $\begin{array}{l}\text { Environmental Compliance Issue } \\
\text { Coordination } \\
\text { (cancels DOE 5400.2) }\end{array}$ & $01-31-89$ \\
\hline & Change 001 & $01-07-93$ \\
\hline 5400.4 & $\begin{array}{l}\text { Comprehensive Environmental Response, } \\
\text { Compensation, and Liability Act } \\
\text { Requirements } \\
\text { (cancels DOE 5480.14, DOE N 5400.4, } \\
\text { and 5400.5) }\end{array}$ & $10-06-89$ \\
\hline \multirow[t]{3}{*}{5400.5} & $\begin{array}{l}\text { Radiation Protection of the Public and the } \\
\text { Environment }\end{array}$ & $02-08-90$ \\
\hline & Change 001 & $06-05-90$ \\
\hline & Change 002 & $01-07-93$ \\
\hline $5440.1 \mathrm{E}$ & $\begin{array}{l}\text { National Environmental Policy Act } \\
\text { Compliance Program } \\
\text { (cancels DOE 5440.1D) }\end{array}$ & $11-10-92$ \\
\hline \multirow[t]{6}{*}{ 5480.1B } & $\begin{array}{l}\text { Environment, Safety, and Health Program } \\
\text { for Department of Energy Operations } \\
\text { (cancels DOE 5480.1A) }\end{array}$ & $09-23-86$ \\
\hline & Change 001 & $02-18-88$ \\
\hline & Change 002 & $01-23-89$ \\
\hline & Change 003 & $07-20-89$ \\
\hline & Change 004 & $03-27-90$ \\
\hline & Change 005 & $05-10-93$ \\
\hline 5480.3 & $\begin{array}{l}\text { Safety Requirements for the Packaging } \\
\text { and Transportation of Hazardous } \\
\text { Materials, Hazardous Substances and } \\
\text { Hazardous Wastes } \\
\text { (cancels Chapter } 3 \text { of DOE 5480.1A) }\end{array}$ & $07-09-85$ \\
\hline \multirow[t]{4}{*}{5480.4} & $\begin{array}{l}\text { Environmental Protection, Safety, and } \\
\text { Health Protection Standards } \\
\text { (cancels Chapter } 1 \text { of DOE 5480.1A) }\end{array}$ & $05-15-84$ \\
\hline & Change 001 & $05-16-88$ \\
\hline & Change 002 & $05-16-89$ \\
\hline & Change 003 & $09-20-91$ \\
\hline ' & Change 004 & $01-07-93$ \\
\hline
\end{tabular}




\begin{tabular}{|c|c|c|}
\hline DOE No. & Subject & Dated \\
\hline 5480.5 & $\begin{array}{l}\text { Safety of Nuclear Facilities } \\
\text { (cancels Chapter } 5 \text { of DOE 5480.1A) }\end{array}$ & $09-23-86$ \\
\hline 5480.6 & $\begin{array}{l}\text { Safety of Department of Energy-Owned } \\
\text { Nuclear Reactors } \\
\text { (cancels Chapter } 6 \text { of DOE 5480.1A) }\end{array}$ & $09-23-86$ \\
\hline $5480.7 A$ & $\begin{array}{l}\text { Fire Protection } \\
\text { (cancels DOE 5480.7) }\end{array}$ & 02-17-93 \\
\hline \multirow[t]{2}{*}{$5480.8 \mathrm{~A}$} & $\begin{array}{l}\text { Contractor Occupational Medical Program } \\
\text { (cancels DOE 5480.8) }\end{array}$ & $06-26-92$ \\
\hline & Change 001 & $10-19-92$ \\
\hline 5480.9 & $\begin{array}{l}\text { Construction Safety and Health Program } \\
\text { (cancels Chapter } 9 \text { of DOE 5480.1A) }\end{array}$ & $11-18-87$ \\
\hline 5480.10 & $\begin{array}{l}\text { Contractor Industrial Hygiene Program } \\
\text { (cancels Chapter } 10 \text { of DOE 5480.1A) }\end{array}$ & $06-26-85$ \\
\hline \multirow[t]{4}{*}{5480.11} & $\begin{array}{l}\text { Radiation Protection for Occupational } \\
\text { Workers } \\
\text { (cancels Chapter II of DOE 5480.1A) }\end{array}$ & $12-21-88$ \\
\hline & Change 001 & $07-20-89$ \\
\hline & Change 002 & $06-29-90$ \\
\hline & Change 003 & $06-17-92$ \\
\hline $5480.13 A$ & $\begin{array}{l}\text { Aviation Safety } \\
\text { (cancels DOE 5480.13) }\end{array}$ & $02-23-93$ \\
\hline 5480.15 & $\begin{array}{l}\text { Department of Energy Laboratory } \\
\text { Accreditation Program for Personnel } \\
\text { Dosimetry }\end{array}$ & $12-14-87$ \\
\hline $5480.16 A$ & $\begin{array}{l}\text { Firearms Safety } \\
\text { (cancels DOE 5480.16) }\end{array}$ & 03-04-94 \\
\hline 5480.17 & Site Safety Representatives & $10-05-88$ \\
\hline $5480.18 A$ & $\begin{array}{l}\text { Accreditation of Performance-Based } \\
\text { Training for Category A Reactors and } \\
\text { Nuclear Facilities } \\
\text { (cancels DOE 5480.18) }\end{array}$ & 07-19-91 \\
\hline \multirow[t]{2}{*}{5480.19} & $\begin{array}{l}\text { Conduct of Operations Requirements for } \\
\text { DOE Facilities }\end{array}$ & $07-09-90$ \\
\hline & Change 001 & $05-18-92$ \\
\hline
\end{tabular}




\begin{tabular}{|c|c|c|}
\hline DOE No. & Subject & Dated \\
\hline 5483.1A & $\begin{array}{l}\text { Occupational Safety and Health Program } \\
\text { for DOE Contractor Employees at } \\
\text { Government-Owned Contractor-Operated } \\
\text { Facilities } \\
\text { (cancels DOE 5483.1) }\end{array}$ & $06-22-83$ \\
\hline \multirow[t]{8}{*}{5484.1} & $\begin{array}{l}\text { Environmental Protection, Safety, and } \\
\text { Health Protection Information Reporting } \\
\text { Requirements }\end{array}$ & $02-24-81$ \\
\hline & Change 001 & $06-29-81$ \\
\hline & Change 002 & $08-13-81$ \\
\hline & Change 003 & $11-06-87$ \\
\hline & Change 004 & $10-17-89$ \\
\hline & Change 005 & $03-15-90$ \\
\hline & Change 006 & $06-29-90$ \\
\hline & Change 007 & $10-17-90$ \\
\hline \multirow[t]{2}{*}{$5500.1 \mathrm{~B}$} & $\begin{array}{l}\text { Emergency Management System } \\
\text { (cancels DOE 5500.1A) }\end{array}$ & 04-30-91 \\
\hline & Change 001 & $02-27-92$ \\
\hline \multirow[t]{2}{*}{$5500.2 \mathrm{~B}$} & $\begin{array}{l}\text { Emergency Categories, Classes, and } \\
\text { Notification and Reporting Requirements } \\
\text { (cancels DOE 5500.2A) }\end{array}$ & $04-30-91$ \\
\hline & Change 001 & $02-27-92$ \\
\hline \multirow[t]{2}{*}{$5500.3 A$} & $\begin{array}{l}\text { Planning and Preparedness for } \\
\text { Operational Emergencies } \\
\text { (cancels DOE 5500.3) }\end{array}$ & 04-30-91 \\
\hline & Change 001 & $02-27-92$ \\
\hline $5500.4 \mathrm{~A}$ & $\begin{array}{l}\text { Public Affairs Policy and Planning } \\
\text { Requirements for Emergencies } \\
\text { (cancels DOE 5500.4) }\end{array}$ & 06-08-92 \\
\hline $5500.5 \mathrm{~A}$ & $\begin{array}{l}\text { Public Affairs Policy and Planning } \\
\text { Requirements for a Fuel Supply } \\
\text { Disruption Emergency } \\
\text { (cancels DOE 5500.5) }\end{array}$ & $06-08-92$ \\
\hline $5500.6 \mathrm{~B}$ & $\begin{array}{l}\text { Shutdown of Departmental Operations } \\
\text { Upon Failure by Congress to Enact } \\
\text { Appropiriations } \\
\text { (cancels DOE 5500.6A) }\end{array}$ & $05-18-92$ \\
\hline
\end{tabular}




\begin{tabular}{|c|c|c|}
\hline DOE No. & Subject & Dated \\
\hline \multirow[t]{2}{*}{5480.20} & $\begin{array}{l}\text { Personnel Selection, Qualification, } \\
\text { Training, and Staffing Requirements at } \\
\text { DOE Reactor and Non-Reactor Nuclear } \\
\text { Facilities }\end{array}$ & $02-20-91$ \\
\hline & Change 001 & $06-19-91$ \\
\hline 5480.21 & $\begin{array}{l}\text { Unreviewed Safety Questions } \\
\text { (cancels paragraph } 5 \text { s of DOE } 5480.5 \text { and } \\
\text { paragraph } 5 x \text { of DOE } 5480.6 \text { and } \\
\text { paragraph } 50 \text { of DOE } 5480.1 B \text { ) }\end{array}$ & $12-24-91$ \\
\hline \multirow[t]{2}{*}{5480.22} & $\begin{array}{l}\text { Technical Safety Requirements } \\
\text { (cancels paragraphs } 5 \mathrm{~h}, 7 \mathrm{e}(4) \text {, and } 8 \mathrm{~d} \text { of } \\
\text { DOE 5480.5; paragraphs } 5 \mathrm{v}, 7 \mathrm{e}(4) \text {, and } 8 \mathrm{~d} \\
\text { of DOE 5480.6) }\end{array}$ & $02-25-92$ \\
\hline & Change 001 & $09-15-92$ \\
\hline \multirow[t]{2}{*}{5480.23} & $\begin{array}{l}\text { Nuclear Safety Analysis Reports } \\
\text { [cancels DOE 5481.1B (nuke facil. only); } \\
\text { paragraphs } 7 \mathrm{~b}(3), 7 \mathrm{e}(3), 8 \mathrm{c} \text { of } \\
\text { DOE } 5480.6 \text {; paragraphs } 51,7 \mathrm{~b}(3), 7 \mathrm{~b}(4) \text {, } \\
7 \mathrm{e}(3), 8 \mathrm{a} \text {, and } 8 \mathrm{~h} \text { of DOE } 5480.5 \text { ] }\end{array}$ & 04-10-92 \\
\hline & Change 001 & 03-10-94 \\
\hline 5480.24 & Nuclear Criticality Safety & 08-12-92 \\
\hline 5480.25 & Safety of Accelerator Facilities & $11-03-92$ \\
\hline 5480.26 & $\begin{array}{l}\text { Trending and Analysis of Operations } \\
\text { Information Using Performance Indicators }\end{array}$ & $01-15-93$ \\
\hline 5480.28 & Natural Phenomena Hazards Mitigation & $01-15-93$ \\
\hline 5480.29 & $\begin{array}{l}\text { Employee Concerns Management System } \\
\text { (cancels Chapter II of DOE 5483.1A, } \\
6-22-83 \text { ) }\end{array}$ & $01-15-93$ \\
\hline 5480.30 & Nuclear Reactor Safety Design Criteria & $01-19-93$ \\
\hline \multirow[t]{2}{*}{ 5481.1B } & $\begin{array}{l}\text { Safety Analysis and Review System } \\
\text { (cancels DOE 5481.1A) (Limited to non- } \\
\text { nuclear) }\end{array}$ & $09-23-86$ \\
\hline & Change 001 & $05-19-87$ \\
\hline \multirow[t]{2}{*}{ 5482.1B } & $\begin{array}{l}\text { Environment, Safety, and Health Appraisal } \\
\text { Program } \\
\text { (cancels DOE 5482.1A) }\end{array}$ & $09-23-86$ \\
\hline & Change 001 & $11-18-91$ \\
\hline
\end{tabular}




\begin{tabular}{|c|c|c|}
\hline DOE No. & Subject & Dated \\
\hline 5500.7B & $\begin{array}{l}\text { Emergency Operating Records Protection } \\
\text { Program } \\
\text { (cancels DOE 5500.7A) }\end{array}$ & 10-23-91 \\
\hline $5500.8 \mathrm{~A}$ & $\begin{array}{l}\text { Energy Emergency Planning and } \\
\text { Management } \\
\text { (cancels DOE 5500.8) }\end{array}$ & 07-08-92 \\
\hline $5500.9 \mathrm{~A}$ & $\begin{array}{l}\text { Emergency Planning, Preparedness, and } \\
\text { Response to Continuity of Government } \\
\text { Emergencies } \\
\text { (cancels DOE 5500.9) }\end{array}$ & 07-08-92 \\
\hline \multirow[t]{2}{*}{5500.10} & Emergency Readiness Assurance Program & $04-30-91$ \\
\hline & Change 001 & $02-27-92$ \\
\hline $5530.1 \mathrm{~A}$ & $\begin{array}{l}\text { Accident Response Group } \\
\text { (cancels DOE 5530.1) }\end{array}$ & 09-20-91 \\
\hline 5530.2 & Nuclear Emergency Search Team & 09-20-91 \\
\hline \multirow[t]{2}{*}{5530.3} & Radiological Assistance Program & 01-14-92 \\
\hline & Change 001 & 04-10-92 \\
\hline 5530.4 & Aerial Measuring System & 09-20-91 \\
\hline \multirow[t]{2}{*}{5530.5} & $\begin{array}{l}\text { Federal Radiological Monitoring and } \\
\text { Assessment Center }\end{array}$ & 07-10-92 \\
\hline & Change 001 & $12-02-92$ \\
\hline $5560.1 \mathrm{~A}$ & $\begin{array}{l}\text { Priorities and Allocations Program } \\
\text { (cancels DOE 5560.1) }\end{array}$ & 05-08-85 \\
\hline 5600.1 & $\begin{array}{l}\text { Management of Department of Energy } \\
\text { Weapon Program and Weapon Complex } \\
\text { (cancels IMD 6001) }\end{array}$ & $06-27-79$ \\
\hline 5610.1 & $\begin{array}{l}\text { Packaging and Transporting of Nuclear } \\
\text { Explosives, Nuclear Components, and } \\
\text { Special Assemblies } \\
\text { (cancels portions Re: Nuclear Explosives } \\
\text { Canceled by DOE } 5610.10 \text { and DOE } \\
5610.11 \text { ) }\end{array}$ & 09-11-79 \\
\hline \multirow[t]{2}{*}{5610.2} & Control of Weapon Data & 08-01-80 \\
\hline & Change 001 & $09-02-86$ \\
\hline 5610.10 & $\begin{array}{l}\text { Nuclear Explosive and Weapon Safety } \\
\text { Program } \\
\text { (cancels DOE } 5610.3 \text { and portions of } \\
\text { DOE } 5610.1 \text { regarding nuclear explosives) }\end{array}$ & $10-10-90$ \\
\hline
\end{tabular}




\begin{tabular}{|c|c|c|}
\hline DOE No. & Subject & Dated \\
\hline 5610.11 & $\begin{array}{l}\text { Nuclear Explosive Safety } \\
\text { (cancels DOE } 5610.3 \text { and portions of } \\
\text { DOE } 5610.1 \text { regarding nuclear explosives) }\end{array}$ & $10-10-90$ \\
\hline 5610.13 & $\begin{array}{l}\text { Joint Department of Energy/Department } \\
\text { of Defense Nuclear Weapons System } \\
\text { Safety, Security, and Control Activities }\end{array}$ & $10-10-90$ \\
\hline 5610.14 & $\begin{array}{l}\text { Transportation Safeguards System Program } \\
\text { Operations }\end{array}$ & $05-12-93$ \\
\hline $5630.8 \mathrm{~A}$ & $\begin{array}{l}\text { Safeguarding of Naval Nuclear Propulsion } \\
\text { Information } \\
\text { (cancels DOE 5630.8) }\end{array}$ & $07-31-90$ \\
\hline $5630.11 \mathrm{~A}$ & $\begin{array}{l}\text { Safeguards and Security Program } \\
\text { (cancels DOE 5630.11) }\end{array}$ & $12-07-92$ \\
\hline $5630.12 A$ & $\begin{array}{l}\text { Safeguards and Security Inspection and } \\
\text { Assessment Program } \\
\text { (cancels DOE 5630.12) }\end{array}$ & $06-23-92$ \\
\hline $5630.13 A$ & $\begin{array}{l}\text { Master Safeguards and Security } \\
\text { Agreements } \\
\text { (cancels DOE 5630.13) }\end{array}$ & 06-08-92 \\
\hline $5630.14 A$ & $\begin{array}{l}\text { Safeguards and Security Program Planning } \\
\text { (cancels DOE 5630.14) }\end{array}$ & 06-09-92 \\
\hline 5630.15 & $\begin{array}{l}\text { Safeguards and Security Training Program } \\
\text { (cancels DOE N 5630.2) }\end{array}$ & $08-21-92$ \\
\hline $5630.16 A$ & $\begin{array}{l}\text { Safeguards and Security Acceptance and } \\
\text { Validation Testing Program } \\
\text { (cancels DOE 5630.16) }\end{array}$ & $06-03-93$ \\
\hline 5630.17 & $\begin{array}{l}\text { Safeguards and Security Standardization } \\
\text { Program } \\
\text { (cancels DOE 5632.10) }\end{array}$ & 09-29-92 \\
\hline 5631.1B & $\begin{array}{l}\text { Security Education Briefing and } \\
\text { Awareness Program } \\
\text { (cancels DOE 5631.1A) }\end{array}$ & $12-31-92$ \\
\hline \multirow[t]{3}{*}{$5631.2 \mathrm{C}$} & $\begin{array}{l}\text { Personnel Security Program } \\
\text { (cancels DOE 5631.2B) }\end{array}$ & $09-15-92$ \\
\hline & Change 001 & $06-07-93$ \\
\hline & Change 002 & $02-17-94$ \\
\hline $5631.4 A$ & $\begin{array}{l}\text { Control of Classified Visits } \\
\text { (cancels DOE 5631.4) }\end{array}$ & $07-08-92$ \\
\hline
\end{tabular}




\begin{tabular}{|c|c|c|}
\hline DOE No. & Subject & Dated \\
\hline $5631.6 \mathrm{~A}$ & $\begin{array}{l}\text { Personnel Security Assurance Program } \\
\text { (cancels DOE 5631.6) }\end{array}$ & 09-15-92 \\
\hline 5632.1B & $\begin{array}{l}\text { Protection Program Operations } \\
\text { (cancels DOE 5632.1A) }\end{array}$ & 09-08-92 \\
\hline \multirow[t]{2}{*}{$5632.2 \mathrm{~A}$} & $\begin{array}{l}\text { Physical Protection of Special Nuclear } \\
\text { Material and Vital Equipment }\end{array}$ & $02-09-88$ \\
\hline & Change 001 & $01-17-89$ \\
\hline \multirow[t]{2}{*}{5632.5} & Physical Protection of Classified Matter & $02-03-88$ \\
\hline & Change 1 & 07-30-93 \\
\hline \multirow[t]{2}{*}{5632.6} & $\begin{array}{l}\text { Physical Protection of DOE Property and } \\
\text { Unclassified Facilities }\end{array}$ & 02-09-88 \\
\hline & Change 001 & $12-05-89$ \\
\hline 5632.7A & $\begin{array}{l}\text { Protective Forces } \\
\text { (cancels DOE 5632.7 thru Change 5) }\end{array}$ & 04-13-94 \\
\hline 5632.8 & $\begin{array}{l}\text { Protection Program Operations-Systems } \\
\text { Performance Tests }\end{array}$ & $02-04-88$ \\
\hline $5632.9 A$ & $\begin{array}{l}\text { Issuance and Control of Security Badges, } \\
\text { Credentials and Shields } \\
\text { (cancels DOE 5632.9; 5631.3) }\end{array}$ & 09-23-92 \\
\hline \multirow[t]{2}{*}{5632.11} & $\begin{array}{l}\text { Physical Protection of Unclassified, } \\
\text { Irradiated Reactor Fuel in Transit } \\
\text { (cancels DOE 1540.4) }\end{array}$ & $09-15-92$ \\
\hline & Change 001 & 03-04-94 \\
\hline $5633.2 A$ & $\begin{array}{l}\text { Control and Accountability of Nuclear } \\
\text { Materials: Responsibilities and } \\
\text { Authorities } \\
\text { (cancels DOE 5633.2) }\end{array}$ & 09-23-92 \\
\hline 5633.3A & $\begin{array}{l}\text { Control and Accountability of Nuclear } \\
\text { Materials } \\
\text { (cancels DOE 5633.3) }\end{array}$ & $02-12-93$ \\
\hline 5633.4 & $\begin{array}{l}\text { Nuclear Materials Transactions: } \\
\text { Documentation and Reporting } \\
\text { (cancels DOE 5630.10) }\end{array}$ & $02-09-88$ \\
\hline 5633.5 & $\begin{array}{l}\text { Nuclear Materials Reporting and Data } \\
\text { Submission Procedures } \\
\text { (cancels DOE 5630.9) }\end{array}$ & $05-22-87$ \\
\hline
\end{tabular}




\begin{tabular}{|c|c|c|}
\hline DOE No. & Subject & Dated \\
\hline 5634.1B & $\begin{array}{l}\text { Facility Approvals, Security Surveys, and } \\
\text { Nuclear Materials Surveys } \\
\text { (cancels DOE 5634.1A) }\end{array}$ & 09-15-92 \\
\hline \multirow[t]{2}{*}{$5635.1 \mathrm{~A}$} & $\begin{array}{l}\text { Control of Classified Documents and } \\
\text { Information } \\
\text { (cancels DOE 5635.1, HQ 5635.1) }\end{array}$ & $02-12-88$ \\
\hline & Change 001 & 06-14-93 \\
\hline $5635.2 B$ & $\begin{array}{l}\text { Protection of Classified National Security } \\
\text { Council Information } \\
\text { (cancels DOE 5635.2A) }\end{array}$ & $04-19-85$ \\
\hline 5635.3 & $\begin{array}{l}\text { Hand-Carrying Classified Matter on Air } \\
\text { Carriers }\end{array}$ & $01-29-88$ \\
\hline \multirow[t]{2}{*}{5635.4} & $\begin{array}{l}\text { Protection of Unclassified Controlled } \\
\text { Nuclear Information }\end{array}$ & 02-03-88 \\
\hline & Change 001 & 04-24-92 \\
\hline $5636.1 \mathrm{~A}$ & $\begin{array}{l}\text { Prohibitions on Illicit Wiretapping and } \\
\text { Eavesdropping } \\
\text { (cancels DOE 5636.1) }\end{array}$ & $06-12-92$ \\
\hline 5639.1 & Information Security Program & $10-19-92$ \\
\hline 5639.3 & $\begin{array}{l}\text { Violation of Laws, Losses, and Incidents } \\
\text { of Security Concerns } \\
\text { (cancels DOE 5631.5) }\end{array}$ & $09-15-92$ \\
\hline \multirow[t]{2}{*}{5639.5} & $\begin{array}{l}\text { Technical Surveillance Countermeasures } \\
\text { Program }\end{array}$ & 08-03-92 \\
\hline & Change 001 & 06-18-93 \\
\hline 5639.6 & Classified Computer Security Program & $09-15-92$ \\
\hline 5639.7 & $\begin{array}{l}\text { Operations Security Program } \\
\text { (cancels DOE 5632.3B) }\end{array}$ & $04-30-92$ \\
\hline $5639.8 \mathrm{~A}$ & $\begin{array}{l}\text { Security of Foreign Intelligence } \\
\text { Information and Sensitive Compartmented } \\
\text { Information Facilities } \\
\text { (cancels DOE 5639.8) }\end{array}$ & $07-23-93$ \\
\hline \multirow[t]{3}{*}{$5650.2 B$} & $\begin{array}{l}\text { Identification of Classified Information } \\
\text { (cancels DOE 5650.2A) }\end{array}$ & $12-31-91$ \\
\hline & Change 001 & $03-27-92$ \\
\hline & Change 002 & 04-28-93 \\
\hline
\end{tabular}




\begin{tabular}{|c|c|c|}
\hline DOE No. & Subject & Dated \\
\hline $5650.3 \mathrm{~A}$ & $\begin{array}{l}\text { Identification of Unclassified Controlled } \\
\text { Nuclear Information } \\
\text { (cancels DOE 5650.3) }\end{array}$ & 06-08-92 \\
\hline $5660.1 \mathrm{~A}$ & $\begin{array}{l}\text { Management of Nuclear Materials } \\
\text { (cancels DOE 5660.1) }\end{array}$ & 07-08-92 \\
\hline $5670.1 \mathrm{~A}$ & $\begin{array}{l}\text { Management and Control of Foreign } \\
\text { Intelligence } \\
\text { (cancels DOE 5670.1) }\end{array}$ & 01-15-92 \\
\hline 5670.3 & Counterintelligence Program & 09-04-92 \\
\hline $5700.2 \mathrm{D}$ & $\begin{array}{l}\text { Cost Estimating, Analysis, and } \\
\text { Standardization } \\
\text { (cancels DOE } 5700.2 \mathrm{C} \text { ) }\end{array}$ & 06-12-92 \\
\hline $5700.5 \mathrm{~A}$ & $\begin{array}{l}\text { Policy and Management Procedures for } \\
\text { Financial Incentives Programs } \\
\text { (cancels DOE 5700.5) }\end{array}$ & 06-08-92 \\
\hline $5700.6 \mathrm{C}$ & $\begin{array}{l}\text { Quality Assurance } \\
\text { (cancels DOE 5700.6B) }\end{array}$ & 08-21-91 \\
\hline $5700.7 \mathrm{C}$ & $\begin{array}{l}\text { Work Authorization System } \\
\text { (cancels DOE 5700.7B) }\end{array}$ & 05-18-92 \\
\hline $5800.1 \mathrm{~A}$ & $\begin{array}{l}\text { Research and Development Laboratory } \\
\text { Technology Transfer Programs } \\
\text { (cancels DOE 5800.1) }\end{array}$ & 05-18-92 \\
\hline $5820.2 A$ & $\begin{array}{l}\text { Radioactive Waste Management } \\
\text { (cancels DOE 5820.2) }\end{array}$ & 09-26-88 \\
\hline $5900.1 \mathrm{~A}$ & $\begin{array}{l}\text { Energy Information Collection, Analysis } \\
\text { and Dissemination } \\
\text { (cancels DOE 5900.1) }\end{array}$ & 05-18-92 \\
\hline $5900.2 \mathrm{~B}$ & $\begin{array}{l}\text { Use of the Metric System of Measurement } \\
\text { (cancels DOE 5900.2A) }\end{array}$ & 04-13-94 \\
\hline $6430.1 \mathrm{~A}$ & $\begin{array}{l}\text { General Design Criteria } \\
\text { (cancels DOE 6430.1) }\end{array}$ & 04-06-89 \\
\hline M 5632.7-1 & Firearms Qualifications Courses Manual & $12-01-92$ \\
\hline N 1000.2 & $\begin{array}{l}\text { Control of Administrative Costs and } \\
\text { Effective Use of Limited Departmental } \\
\text { Resources }\end{array}$ & 01-07-93 \\
\hline N $1100.32 A$ & $\begin{array}{l}\text { Departmental Organization and } \\
\text { Management } \\
\text { (cancels DOE 1100.32) }\end{array}$ & 06-10-93 \\
\hline
\end{tabular}




\begin{tabular}{|c|c|c|}
\hline DOE No. & Subject & Dated \\
\hline N 1100.34 & $\begin{array}{l}\text { Abolishment of the Office of New } \\
\text { Production Reactors }\end{array}$ & 04-13-93 \\
\hline N 1100.35 & $\begin{array}{l}\text { Title Changes for the Office of } \\
\text { Intelligence and National Security }\end{array}$ & 03-03-94 \\
\hline N 1120.5 & $\begin{array}{l}\text { Relocation of San Francisco Operations } \\
\text { Office }\end{array}$ & $04-30-93$ \\
\hline N 1120.6 & Operations Office Name Change & 02-03-94 \\
\hline N 1240.2 & $\begin{array}{l}\text { Unclassified Foreign National Visits and } \\
\text { Assignments }\end{array}$ & $11-29-93$ \\
\hline N 1130.3 & Departmental Conference Activity & $03-10-93$ \\
\hline N 1321.136 & New Directives System Implementation & $01-04-93$ \\
\hline N 1321.138 & $\begin{array}{l}\text { Departmental Directives System: Interim } \\
\text { Improvement Notice } 2\end{array}$ & $02-16-93$ \\
\hline N 1321.139 & $\begin{array}{l}\text { Cancellation of Directives } \\
\text { (cancels DOE 0000.1A, 0000.2D, 1100.71, } \\
\text { 1100.8A, 1130.7B, 1200.1A, 1280.1A, } \\
\text { 1320.1, 1321.1B, 1321.2C, 1322.3C, } \\
\text { 1322.4B, 1323.3A, 1323.4C, 1324.7A, } \\
\text { 1325.1A, 1325.2, 1360.7A, 1370.2A, } \\
\text { 1410.1B, 1450.2C, 1900.1E, 1900.2C, } \\
\text { 1900.3A, 2020.1A, 3240.1A, 3308.1, } \\
3792.2 \mathrm{~A}, 4210.3 \mathrm{D}, 4510.1 \mathrm{~B}, 5400.3 \text {, } \\
\text { SEN-00-93, SEN-12B-91) }\end{array}$ & 03-25-94 \\
\hline N 1324.13 & $\begin{array}{l}\text { Disposition of Personal Papers and } \\
\text { Official Records }\end{array}$ & $11-09-92$ \\
\hline N 1325.24 & Distribution of Correspondence & 08-13-92 \\
\hline N 1325.25 & Distribution of Correspondence & 08-23-93 \\
\hline N 1360.9 & $\begin{array}{l}\text { Protection of Portable Computers While } \\
\text { in Travel Status }\end{array}$ & $12-07-92$ \\
\hline N 1500.47 & $\begin{array}{l}\text { Acceptance of Payment From a } \\
\text { Non-Federal Source for Travel Expenses }\end{array}$ & $11-12-92$ \\
\hline N 1600.32 & $\begin{array}{l}\text { United States Holocaust Memorial } \\
\text { Museum and the Annual Commemoration } \\
\text { of Days of Remembrance }\end{array}$ & 04-14-93 \\
\hline N 1600.33 & Cancellation of DOE N 1600.31 & $07-27-93$ \\
\hline N 2030.7A & $\begin{array}{l}\text { Reporting Fraud, Waste, and Abuse } \\
\text { (cancels DOE N 2030.7) }\end{array}$ & $07-21-93$ \\
\hline N 2200.15 & Taxation of Non-Cash Fringe Benefits & $11-19-92$ \\
\hline
\end{tabular}




\begin{tabular}{|c|c|c|}
\hline DOE No. & Subject & Dated \\
\hline N 2321.2 & $\begin{array}{l}\text { Cancellation of DOE N } 2321.1 \\
\text { (cancels DOE N 2321.1) }\end{array}$ & 09-28-92 \\
\hline N 3300.2 & $\begin{array}{l}\text { Ceiling Exemption for the Hiring of } \\
\text { People with Disabilities }\end{array}$ & 03-18-93 \\
\hline N 3410.20 & $\begin{array}{l}\text { Exceptions to the Constraints on } \\
\text { "Academic Degree Training" to Relieve } \\
\text { Recruitment and Retention Problems }\end{array}$ & 08-03-93 \\
\hline N 3430.2 & $\begin{array}{l}\text { Departmental Performance Appraisal } \\
\text { System }\end{array}$ & 08-19-93 \\
\hline N 3450.31 & Time Off Awards & 07-06-93 \\
\hline N 3735.21 & $\begin{array}{l}\text { Initial Department of Energy Employee } \\
\text { Orientation on New Uniform Standards of } \\
\text { Ethical Conduct for Executive Branch } \\
\text { Employees }\end{array}$ & $12-16-92$ \\
\hline N 3735.22 & $\begin{array}{l}\text { Annual Submission of Financial Disclosure } \\
\text { Reports }\end{array}$ & 04-19-93 \\
\hline N 3735.23 & $\begin{array}{l}\text { Annual Submission of Financial Disclosure } \\
\text { Reports }\end{array}$ & 04-25-94 \\
\hline N 3792.8 & $\begin{array}{l}\text { Drug-Free Workplace Program for } \\
\text { Federal Employees }\end{array}$ & 04-22-93 \\
\hline N 3870.21 & $\begin{array}{l}\text { Federal Employees' Group Life Insurance } \\
\text { Program Open Enrollment Period and } \\
\text { Rate Reduction }\end{array}$ & 03-10-93 \\
\hline N 4300.3 & Broad Agency Announcements & $11-09-92$ \\
\hline N 4300.4 & $\begin{array}{l}\text { Space Nuclear and Non-Commercial } \\
\text { Power Reactor and Radioisotope Power } \\
\text { Work for Others }\end{array}$ & 01-14-93 \\
\hline N 4300.5 & Extension of DOE N 4300.4 & 01-14-94 \\
\hline N 4700.5 & $\begin{array}{l}\text { Project Control System Guidelines } \\
\text { (cancels DOE 2250.1D) }\end{array}$ & 08-21-92 \\
\hline N 4700.6 & $\begin{array}{l}\text { Extension of DOE N } 4700.5 \text { (Project } \\
\text { Control System Guidelines) }\end{array}$ & $06-07-93$ \\
\hline N 4700.7 & Project Manager Certification & 04-13-94 \\
\hline N 5400.7 & Coordination Process for Agreements & $10-22-90$ \\
\hline N 5400.9 & Sealed Radioactive Source Accountability & $12-24-91$ \\
\hline N 5400.10 & $\begin{array}{l}\text { Extension of DOE N 5400.9, Sealed } \\
\text { Source Accountability }\end{array}$ & 12-11-92 \\
\hline
\end{tabular}




\begin{tabular}{|c|c|c|}
\hline DOE No. & Subject & Dated \\
\hline N 5400.11 & Extension of DOE N 5400.7 & $01-22-93$ \\
\hline N 5400.12 & Extension of DOE N 5400.9 & $12-23-93$ \\
\hline N 5480.5 & $\begin{array}{l}\text { Imposition of Proposed Nuclear Safety } \\
\text { Requirements } \\
\text { (cancels extended to 1-22-94 by DOE } \\
\text { N 5480.7) }\end{array}$ & $01-22-92$ \\
\hline N 5480.6 & Radiological Control & $06-17-92$ \\
\hline N 5480.7 & Extension of DOE N 5480.5 & 01-07-93 \\
\hline N 5480.8 & Radiological Health and Safety Policy & 06-08-93 \\
\hline N 5484.1 & $\begin{array}{l}\text { Requirements for Investigations of } \\
\text { Departmental Fatalities and Serious } \\
\text { Accidents }\end{array}$ & 03-24-94 \\
\hline N $5630.3 A$ & $\begin{array}{l}\text { Protection of Departmental Facilities } \\
\text { Against Radiological and Toxicological } \\
\text { Sabotage } \\
\text { (cancels DOE N 5630.3) }\end{array}$ & $06-28-93$ \\
\hline N 5631.3 & $\begin{array}{l}\text { Visitor Access Control Procedures } \\
\text { (cancels DOE N 5631.2) }\end{array}$ & 03-24-93 \\
\hline N 5635.10A & $\begin{array}{l}\text { Classified Mailing Addressees } \\
\text { (cancels DOE N 5635.10) }\end{array}$ & 01-28-94 \\
\hline N 5639.1 & $\begin{array}{l}\text { Classified Matter in Sensitive } \\
\text { Compartmented Information Facilities }\end{array}$ & 07-02-93 \\
\hline N 5900.2 & Use of the Metric System & 04-08-92. \\
\hline N 5900.3 & Extension of DOE N 5900.2 & 03-31-93 \\
\hline
\end{tabular}




\begin{tabular}{|c|c|c|}
\hline DOE-HQ No. & Subject & Dated \\
\hline 1130.2 & $\begin{array}{l}\text { Establishment of Fuel Technology } \\
\text { Review Committee }\end{array}$ & 03-31-93 \\
\hline 1130.3 & $\begin{array}{l}\text { Headquarters Affirmative Action } \\
\text { Advisory Council }\end{array}$ & $10-05-81$ \\
\hline $1324.1 \mathrm{~A}$ & $\begin{array}{l}\text { Records Management } \\
\text { (cancels HQ 1324.1) }\end{array}$ & $01-08-87$ \\
\hline 1325.1 & $\begin{array}{l}\text { Action Coordination and Tracking } \\
\text { System } \\
\text { (cancels IMD 0504) }\end{array}$ & 07-30-79 \\
\hline \multirow[t]{4}{*}{1400.1} & $\begin{array}{l}\text { Personal Property and Supply } \\
\text { Management }\end{array}$ & $12-30-80$ \\
\hline & Change 001 & $08-12-81$ \\
\hline & Change 002 & 08-18-82 \\
\hline & Change 003 & $12-21-83$ \\
\hline $1400.2 B$ & $\begin{array}{l}\text { Parking Management } \\
\text { (cancels HQ 1400.2A) }\end{array}$ & $06-04-85$ \\
\hline 1430.1 & Library Services & $05-24-88$ \\
\hline $2100.1 \mathrm{~A}$ & $\begin{array}{l}\text { Financial Management of Money } \\
\text { Received From Persons Who Have } \\
\text { Allegedly Violated Department of } \\
\text { Energy Regulations } \\
\text { (cancels HQ 2100.1) }\end{array}$ & 05-11-81 \\
\hline 2100.2 & $\begin{array}{l}\text { Low-Level Radioactive Waste } \\
\text { Surcharge Escrow Account }\end{array}$ & $04-15-87$ \\
\hline 3293.1 & Personnel Records & $01-18-84$ \\
\hline 3300.1 & $\begin{array}{l}\text { Details, Temporary and Term } \\
\text { Promotions }\end{array}$ & $11-21-83$ \\
\hline 3335.1 & Merit Promotion Plan & $03-13-87$ \\
\hline 3430.1 & $\begin{array}{l}\text { Headquarters Performance } \\
\text { Appraisal Plan }\end{array}$ & $06-21-84$ \\
\hline 3511.1 & Position Classification & $06-06-86$ \\
\hline \multirow[t]{2}{*}{ 3600.1B } & $\begin{array}{l}\text { Emergency and Hazardous Weather } \\
\text { Dismissals } \\
\text { (cancels HQ 3600.1A) }\end{array}$ & $02-07-84$ \\
\hline & Change 1 & $05-09-84$ \\
\hline
\end{tabular}




\begin{tabular}{lll}
\hline \multicolumn{1}{c}{ DOE-HQ No. } & \multicolumn{1}{c}{ Subject } & Dated \\
\hline 3710.1 & $\begin{array}{l}\text { Labor-Management Relations } \\
\text { Program }\end{array}$ & $07-18-83$ \\
3790.1 & $\begin{array}{l}\text { Occupational Health Program } \\
\text { 3790.2A }\end{array}$ & $04-29-83$ \\
& $\begin{array}{l}\text { Headquarters Occupational Safety } \\
\text { and Health Program } \\
\text { (cancels HQ 3790.2) }\end{array}$ & $03-13-87$ \\
3792.1 & $\begin{array}{l}\text { Employee Assistance Program } \\
5632.1\end{array}$ & $07-23-84$ \\
5632.2 & $\begin{array}{l}\text { Forrestal Security and Safety } \\
\text { Procedures }\end{array}$ & $02-02-83$ \\
& $\begin{array}{l}\text { Search and Access Control } \\
\text { Procedures for Headquarters }\end{array}$ & $02-18-88$ \\
& $\begin{array}{l}\text { Facilities } \\
\text { Change 001 }\end{array}$ & $08-11-89$ \\
5636.1 & $\begin{array}{l}\text { Security Requirements for Classified } \\
\text { Automatic Data Processing Systems }\end{array}$ & $07-10-85$ \\
\hline
\end{tabular}


Appendix B

\section{REGULATION AND PART AND SECTION NUMBERS FOR DEFINITIONS}


Some of the definitions used in this document are included in the following sections of the Regulations.

Regulation

49 CFR
Part No.

107 Hazardous Materials Program Procedures

110

Hazardous Materials Public Sector Training and Planning Grants

171 General Information, Regulations, and Definitions

173 Shippers-General Requirements for Shipments and Packagings
Section No.

107.3

107.299

110.20

171.8

173.50

173.115

173.120

173.127

173.128

173.132

173.134

173.136

173.140

173.144

173.403

176 Carriage By Vessel

176.2

178 Shipping Container Specifications

178.500

179.2

180.403

180 Continuing Qualification and Maintenance of Packagings

350 Commercial Motor Carrier Safety Assistance Program

350.3

355.5

Regulations Affecting Interstate Motor

Carrier Operations

383 Commercial Driver's License

Standards; Requirements and Penalties

383.5

385 Safety Fitness Procedures

385.3

386 Rules of Practice for Motor Carrier Safety and Hazardous Materials Proceedings 
387 Minimum Levels of Financial Responsibility

389 Rulemaking Procedures - Federal Motor

389.3

Carrier Safety Regulations

390 Federal Motor Carrier Safety Regulations;

General

390.5

391 Qualifications of Drivers

391.85

393 Parts and Accessories Necessary for Safe

393.5

Operation

$395 \quad$ Hours of Service of Drivers

395.2

398 Transportation of Migrant Workers

398.1

399 Employee Safety and Health Standards

399.205

29 CFR

1910.1200 Hazard Communication

10 CFR

$2 \quad$ Rules of Practice for Domestic Licensing

Proceedings and Issuance of Orders

2.4

2.902

2.1105

19 Notices, Instructions and Reports to

Workers: Inspections and Investigations

20 Standards for Protection Against Radiation

20.1003

30 Rules of General Applicability to Domestic Licensing of Byproduct Material

30.4

32 Specific Domestic Licenses to Manufacture

32.2 or Transfer Certain Items Containing Byproduct Material

34 Licenses for Radiography and Radiation

34.2

Safety Requirements for Radiographic Operations

35 Medical Use of Byproduct Material 
50 Domestic Licensing of Production and Utilization Facilities

51 Environmental Protection Regulations for

Domestic Licensing and Related Regulatory

Functions

Adequacy of Available Spent Nuclear Fuel Storage Capacity

Disposal of High-Level Radioactive Wastes in Geological Repositories of Radioactive Waste Material

$71 \quad$ Packaging and Transportation of

Licensing Requirements or the Independent Storage of Spent Nuclear Fuel and HighLevel Radioactive Waste

Material Control and Accounting of Special Nuclear Material of National Security Information and Restricted Data 
140 Financial Protection Requirements and Indemnity Agreements

150 Exemptions and Continued Regulatory Authority in Agreement States and in Offshore Waters Under Section 274 
ORNL/M-3077

\section{INTERNAL DISTRIBUTION}

1. C. J. Armstrong

2. J. M. Begovich

3. R. G. Bugos

4. A. G. Croff

5. L. S. Dickerson

6. K. F. Eckerman

7. W. Fulkerson

8-12. R. M. Gove

13. R. F. Holdaway

14. S. D. Jennings

15. F. M. Kovac

16. L. E. McNeese

17. C. V. Parks

18. R. B. Pope

19. J. E. Ratledge

20. R. R. Rawl

21. D. E. Reichle

22. P. S. Rohwer
23. L. B. Shappert

24. A. W. Trivelpiece

25. R. M. Walker

26. M. W. Wankerl

27-131. M. J. Welch

132. B. W. Welles

133. R. M. Westfall

134. G. E. Whitesides

135. D. L. Williams, Jr.

136. S. J. Wolfe

137. Central Research Library

138. Document Reference Section

139. Laboratory Protection Division

140-141. Laboratory Records Department

142. Laboratory Records - RC

143. ORNL Patent Section

144. ORNL Public Relations Office

\section{EXTERNAL DISTRIBUTION}

145-149. J. W. Arendt, 109 Caldwell, Oak Ridge, TN 37831.

150. R. W. Barber, Director, Office of Risk Analysis and Technology, U. S. Department of Energy, EH-33, Washington, D.C. 20585.

151. M. L. Bennett, DOE-OR, P.O. Box 2001, Oak Ridge, TN 37831.

152. L. G. Blalock, Director, Transportation Management Division, U. S. Department of Energy, EM-261, Washington, D.C. 20585.

153. George Brown, Radioactive Materials Branch, Office of Hazardous Materials Technology (DHM-23), U. S. Department of Transportation, 400 Seventh St., SW, Washington, D.C. 20590.

154. W. Carriker, Radioactive Materials Branch, Office of Hazardous Materials Technology (DHM-23), U. S. Department of Transportation, 400 Seventh St., SW, Washington, D.C. 20590.

155. J. Cece, 7004 Kepner Court, Lanham, MD 20706. 
156. C. R. Chappell, U. S. Nuclear Regulatory Commission, Transportation Branch NMSS, One White Flint North, MS-4E4, Washington, D.C. 20555.

157. A. Kapoor, Transportation and Packaging Safety Division, U. S. Department of Energy, EH-332, Washington, D.C. 20585.

158. R. E. Luna, Systems Safety Technology Division, Sandia Laboratories, P.O. Box 5800, Albuquerque, NM 87185.

159. E. B. McNeil, Transportation Management Division, U. S. Department of Energy, EM-261, Washington, D.C. 20585.

160-169. T. S. Needels, Transportation and Packaging Safety Division, U. S. Department of Energy, EH-332, Washington, D.D. 20585.

170-171. Office of Scientific and Technical Information, P.O. Box 62, Oak Ridge, TN 37831.

172. J. M. Shuler, Transportation and Packaging Safety Division, U. S. Department of Energy, EH-332, Washington, D.C. 20585.

173. W. R. Rhyne, H\&R Technical, Associates, Inc., P.O. Box 215, Oak Ridge, TN 37831.

174. D. F. Stancell, DOE-OR, P.O. Box 2001, Oak Ridge, TN 37831.

175. M. E. Wangler, Director, Transportation and Packaging Safety Division, U. S. Department of Energy, EH-332, Washington, D.C. 20585.

176. D. M. Willaford, DOE-OR, P.O. Box 2001, Oak Ridge, TN 37831.

177. Assistant Manager of Energy Research and Development, P.O. Box 2008, Oak Ridge, TN 37831-6269. 